\title{
INSTRUMENTS OF GAIA
}

\author{
by \\ Matthew Ferguson \\ B. Arch. Sc. , Ryerson University \\ 2016 \\ A thesis \\ presented to Ryerson University \\ in partial fulfillment of the \\ requirements for the degree of \\ Master of Architecture \\ in the Program of \\ Architecture
}

Toronto, Ontario, Canada, 2019

(C) Matthew Ferguson 2019 


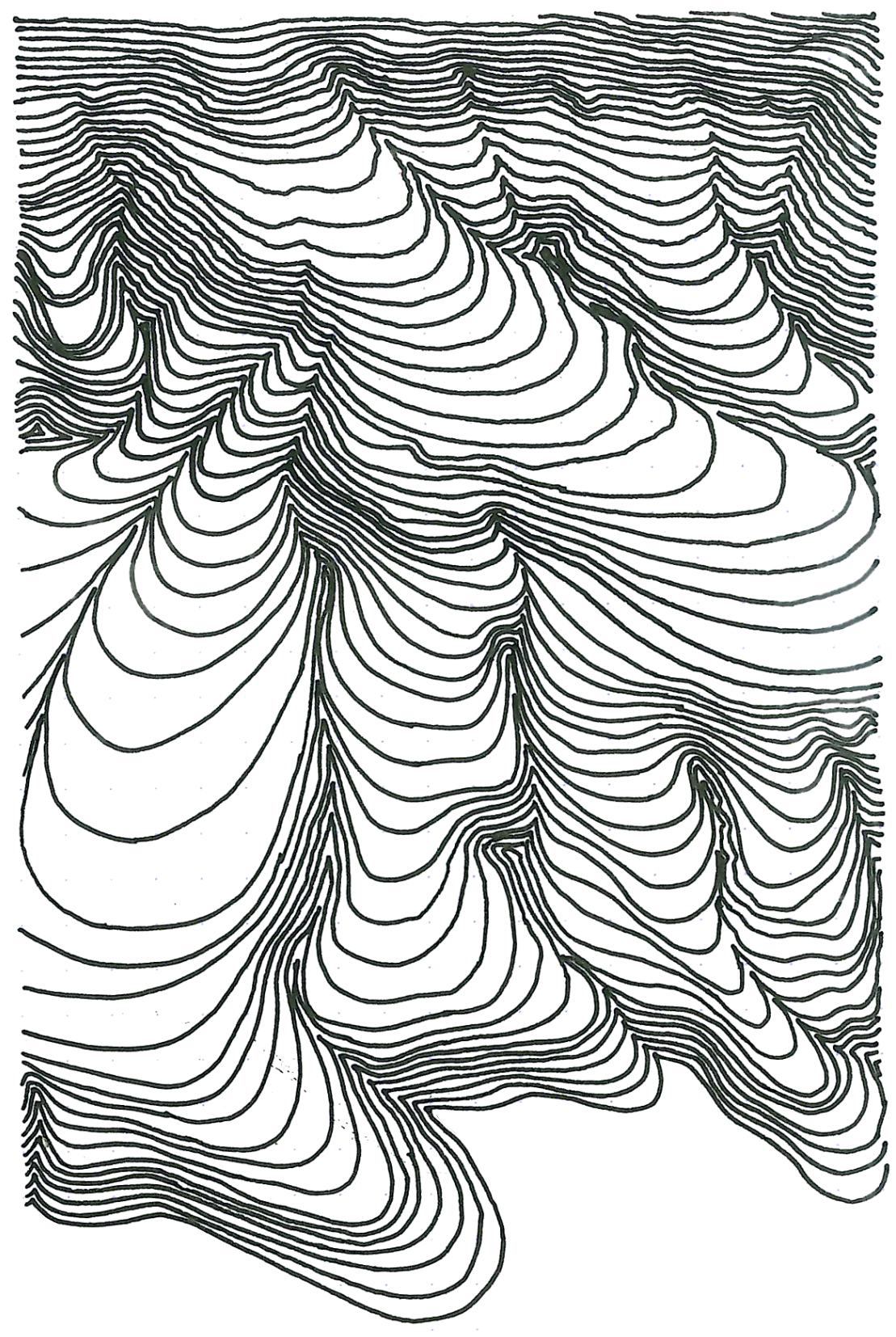




\section{AUTHOR'S DECLARATION FOR ELECTRONIC SUBMISSION OF A THESIS}

I hereby declare that I am the sole author of this

thesis. This is a true copy of the thesis, including any required final revisions, as accepted by my examiners.

I authorize Ryerson University to lend this thesis to other institutions or individuals for the purpose of scholarly research.

I further authorize Ryerson University to reproduce this thesis by photocopying or by other means, in total or in part, at the request of other institutions or individuals for the purpose of scholarly research.

I understand that my thesis may be made electronically available to the public. 


\section{abstract}

Instruments of Gaia

M.Arch, 2019

Matthew Ferguson

Masters of Architecture, Ryerson University 
Instruments of Gaia is a thesis which interviews the role of architecture as an interface between nature and human experience. The contained argument is a critique on architecture's reliance on climatic mitigation; whereas relationships between site and user are nullified through concealed building systems. This thesis project as a counterpoint explores new ideas of architectural design and expression as a register for and active agent in the anthropocene where the magnification and understanding of place and site plays a key role in the development of the climatic imagination needed ever more, to grapple with human impact on the very ground we rest our foundations upon.

Architectural expression as an intuitive, didactic mechanism and amplifier of this relationship is explored through the collapsing of multidisciplinary research, and expression of the fragility, and enormity of Gaia as a new secular mythos of the cosmos, and the embedding of these new myths, through weathering and geologic time scales, into an architectural project. The experiential memories formed within this expanded field of architecture constitute a new body of sensible knowledge. The art of architecture offers the medium with which to collapse these assemblages into poetic space and memory, and the beginning of a new dialogue with the Gaia of the Anthropocene. 


\section{acknowledgements}

Cheryl Atkinson

Garth Norbraten

Colin Ripley

My Friends, Colleagues, and Companions

My Family 
I would like to take this space to thank the individuals without whose support and companionship this thesis wouldn't have been possible.

For your constant belief in my work and crucial guidance. Your insights have helped me not just to produce a thesis, but to gain a deeper understanding of my own beliefs and values in the process.

For the ingenious connections and challenges you've put forth to me which have challenged my thinking, my design process, and the multidisciplinary reach of my work since the beginning.

For your insightful and critical insights along the journey of this thesis, and for reminding me not simply to aim to finish a thesis, but to challenge my own limits in the process

For being the source of some of my greatest inspiration, broadening my horizons, for reminding me that in addition to creating buildings, drawings, and ideas, we must also take the time to make beautiful memories along the way.

For loving and supporting me unconditionally throughout my academic career, while asking for so little in return. Words cannot express my gratitude for your constant belief in me. 
and Darius Codrea. 


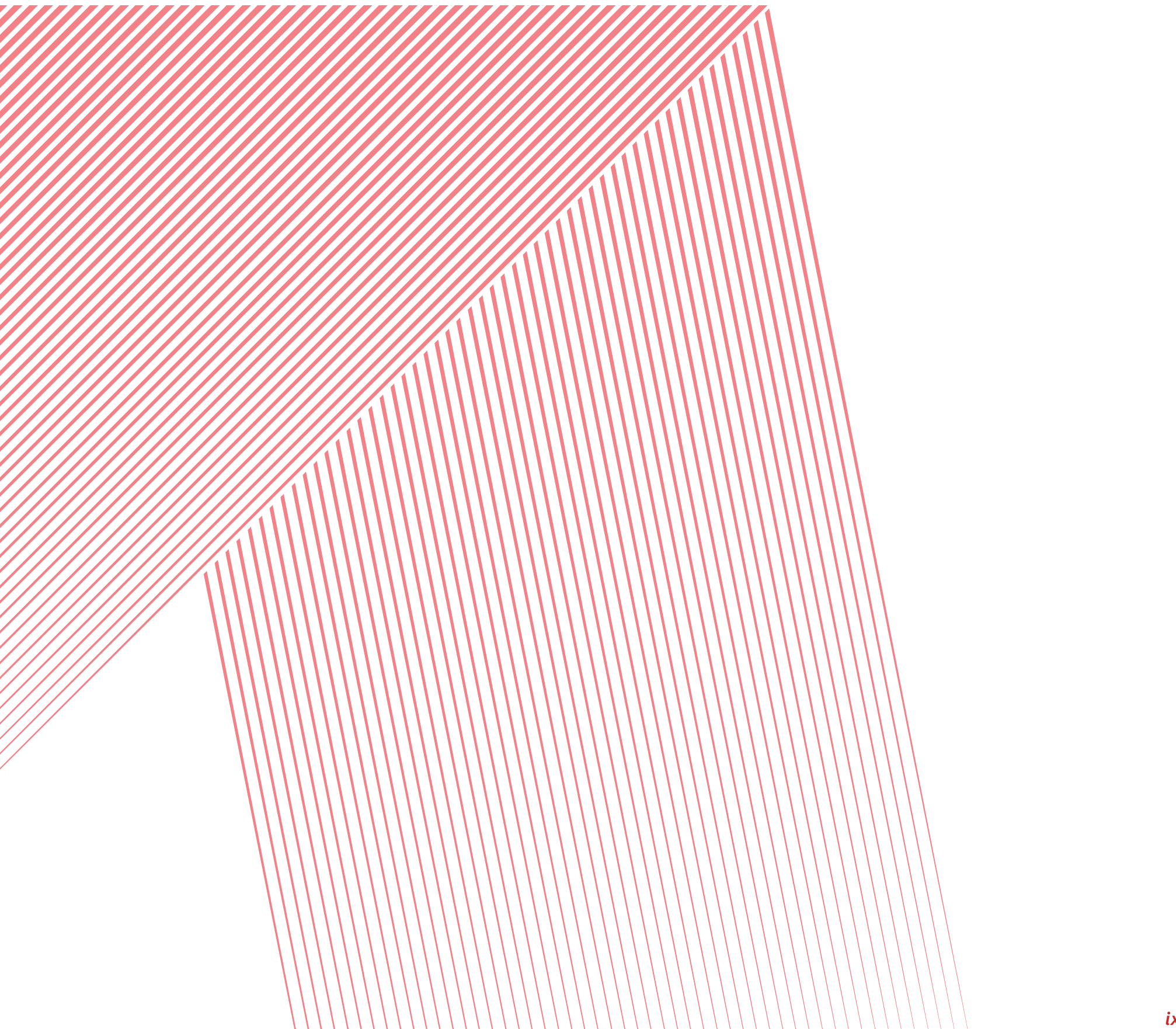




$$
\begin{gathered}
\text { table of } \\
\text { contents }
\end{gathered}
$$




\section{On Nature}

i) Human vs. Nature in history and thought 05

ii) Organic Architecture

iii) Invisible Architecture

iv) Biomimetic Architecture

v) Land Art as Cosmological Link

\section{2. conceiving of the planet}
i) The Climatic Imaginary 41
ii) The Agency of the Architect
iii) The Role of the Architect in the Environment

\section{3. on becoming an instrument}

i) Instrument Knowledge 85

ii) Case studies in Interaction

iii) Conclusions

\section{4. calibration}
i) Fresh Water Globally 87
ii) The Great Lakes $x x$
iii) Johnson Bay Conservation and Wetlands $x x$

\section{5. the instrument \\ i) On Site Selection 119 \\ ii) The Instrument $x x$ \\ iii) Mapping $\mathrm{xx}$ \\ iv) Selected Illustrations $\mathrm{xx}$}

\section{end matter}

Bibliography $x x$

Index $x x$ 


\section{list of
figures}

Figure 1: Embracing Landscapes (Mimesis) - Barbara and Michael Leisgen

Figure 2: Watertower Series - Bernd and Hilla Becher

Figure 3: Berlin Philharmonic - Hans Scharoun

Figure 4: Kaufmann Residence - Frank Lloyd Wright

Figure 5: Petra Cave Dwellings

Figure 6: Tree Hotel by Tham - Videgard Arkitekter

Figure 7: Gherkin Tower - Norman Foster

Figure 8: ICD/ITKE Research Pavilion - University of Stutgart

Figure 9: "Wet" - Andy Goldsworthy

Figure 11: "Spiral Jetty" - Robert Smithson

Figure 10: "A Line Made By Walking" - Richard Long

Figure 12: The "Blue Marble" photograph of the earth, Taken during the Apollo 17 mission on December 7 ,

1972, Nasa Johnson Space Centre

Figure 13: Gaia Global Circus: A Climate Tragicomedy pg. 52

Figure 14: Gaia Global Circus: A Climate Tragicomedy pg. 52

Figure 15: Gaia Global Circus: A Climate Tragicomedy pg. 52

Figure 16: Bosco Verticale - Rendering

Figure 17: Bosco Verticale - Built

Figure 18: Rendering of Toronto CLT Forest Towerby Penda / TMBR

Figure 19: A Stanley's Theolodite

Figure 22: Colour Mixing Apparatus

Figure 20: WW1 Dial Sight

Figure 23: Aperiodic Mirror Galvanometer

Figure 21: Graphoscope

Figure 24: McMath-Pierce Solar Telescope at the Kitt Peak National Observatory, designed by Skidmore

Owings \& Merrill 
Figure 25: Taxonomy of interactive architecture

Figure 26: Shadowboxx

Figure 27: Strandbeest

Figure 28: Dissolving Arch

Figure 29: Taxonomy of interactive architecture types

Figure 30: eProject Location, National Scale

Figure 31: Significant Islands, Northeast Lake Ontario

Figure 32: Coservation Authority Boundary Extents

Figure 33: Conservation Legislature Diagram

Figure 34: Conservation Legislature Diagram

Figure 35: "Measuring Land and Sea" - Oliver Jeffers 


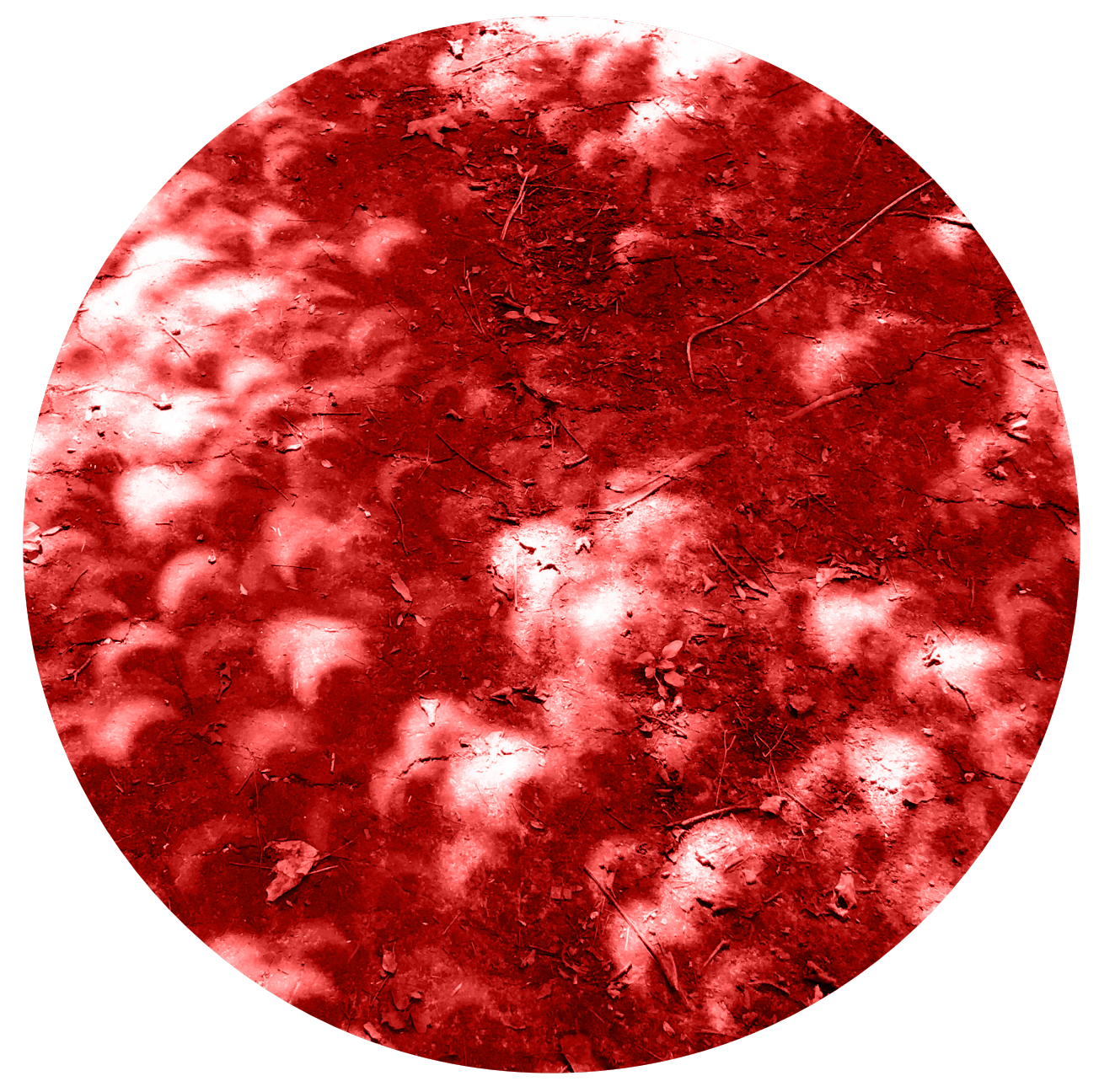




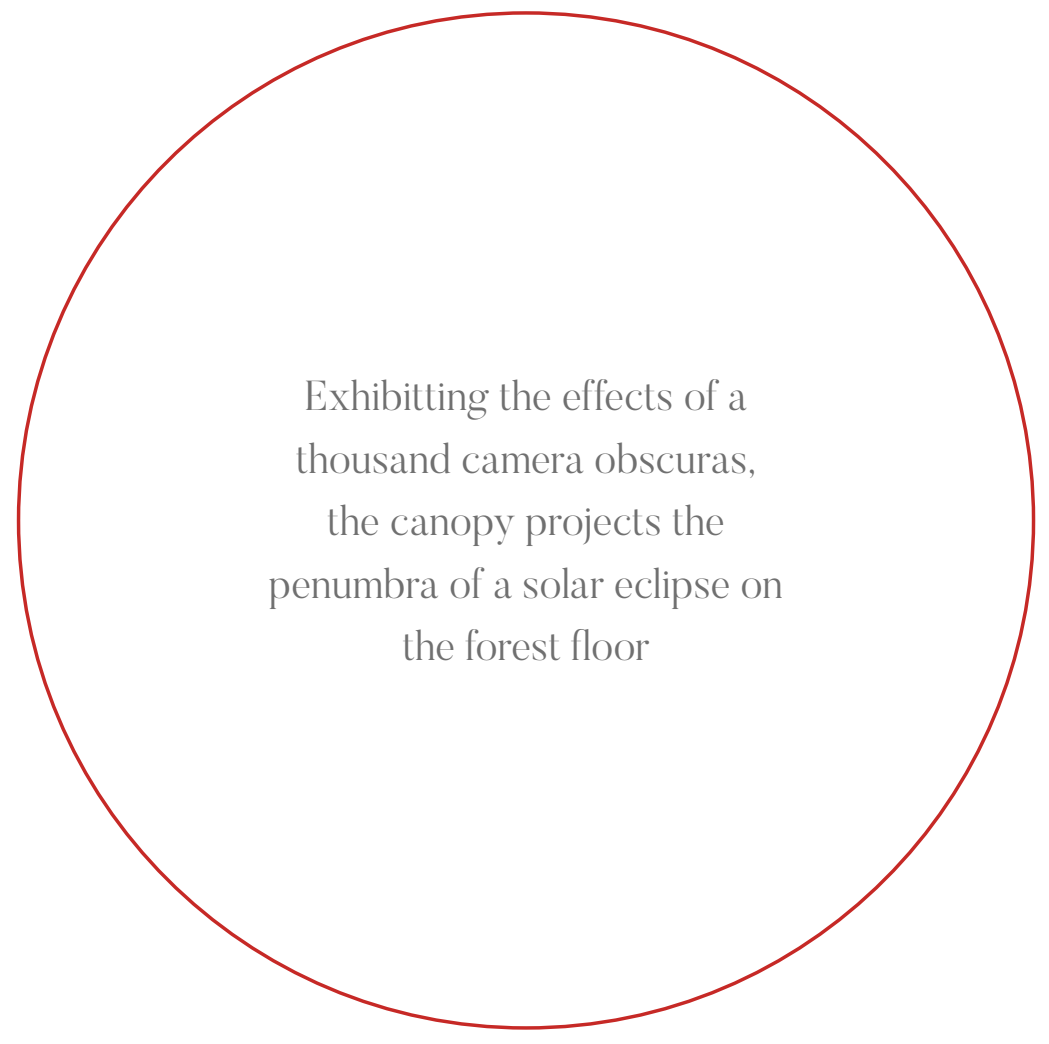




\section{Introduction}

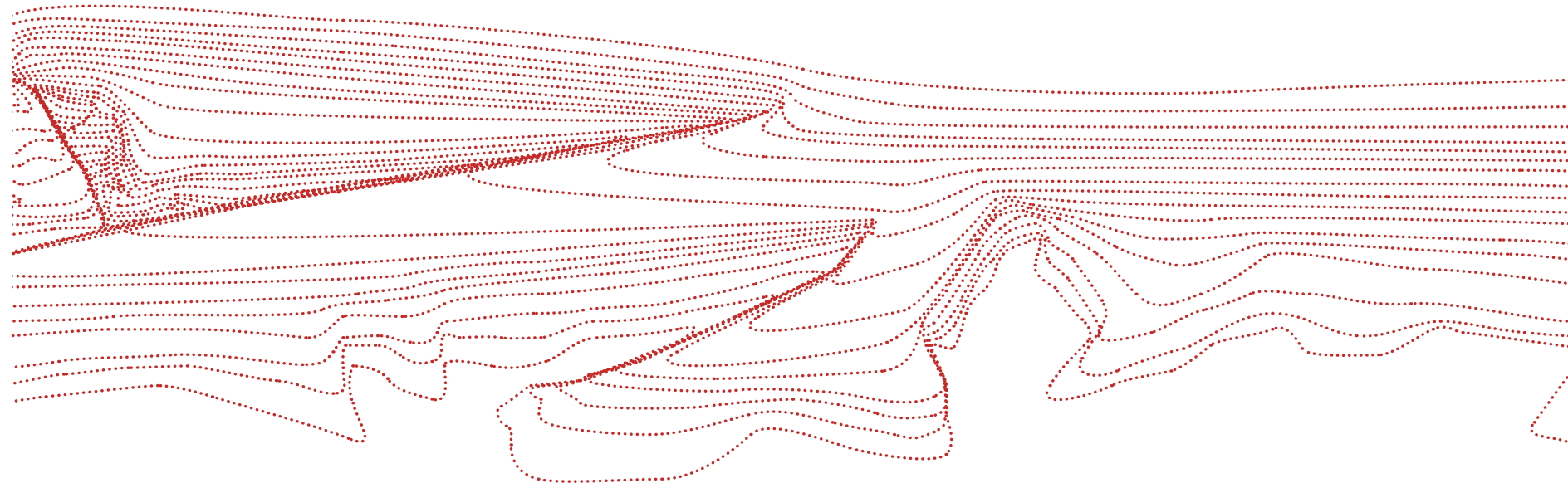

At the forefront of architectural design labs, the idea of physically adaptive and motive architectures of the future seem more and more achievable through complex material and system engineering, as well as parallel advances in other sciences. These advances have served a great boon to a complex industry, BIM technologies reduce risk and allow for the fabrication of complex forms with ease, digital modelling allows us to derive principles and structures from materials that can only be exposed under the algorithmic microscope. The field of architecture grows ever broader, and ever more complex. However industrial and now technological revolution have also had inverse effects on the broader world. Alleviation of the need for passive conditioning strategies has enabled the construction of buildings supported on crutches by their mechanical systems, increasing reliance on fossil fuels over the past 50 years and unknowingly playing our part in the acceleration of global warming. Simultaneously, the removal of the user from the need to open windows, shut the blinds and otherwise interact with the threshold between climate and architecture has enabled the general public, by no fault of their own, to discard some of the intuitive knowledge of daily and yearly climate rhythms in in the building. Paired with the scale of the issues now facing the planet, the combination of these issues results in a 


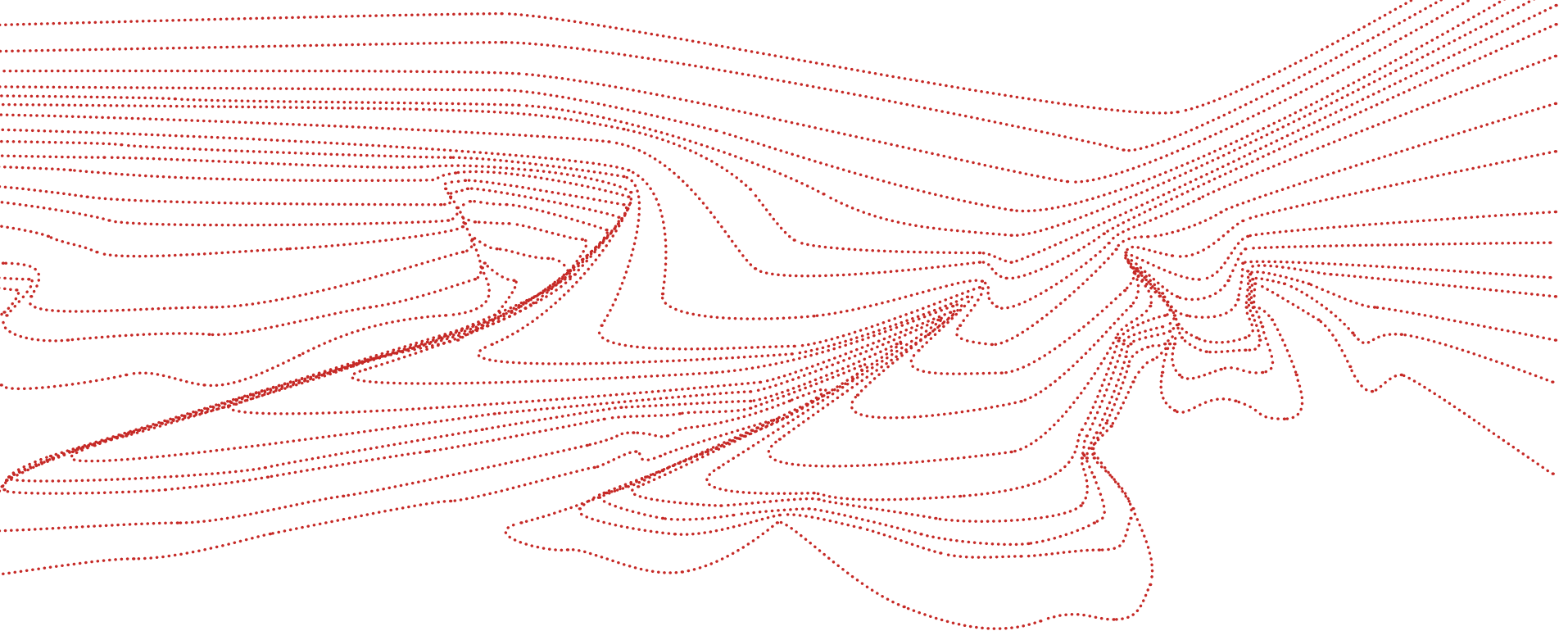

culture where very little connection exists

between an individual and the great problem of climate, other than through intellect.

This divide cannot be battled singularly or holistically. However, as a discipline inherently embedded in its environment, architecture sits in a unique position to become an instrument in long-term change for the environmental sciences. Using the tools and strategies of architectural expression and intent, and seeing the site as a client, design can become illustrative and a measurement of changes in the environment that magnifies and enhances the connection between the user and the site. Furthermore, it is positted here that the design choices which will be made in the creation of this architectural instrument can have new tectonic and social ramifications for architecture. Develloping new strategies and frameworks for interactive design elements, exploring open ended systems for facade and spatial configuration, as well as creating experiences for the visitor which are unique, evocative, and intensely site-specific. 


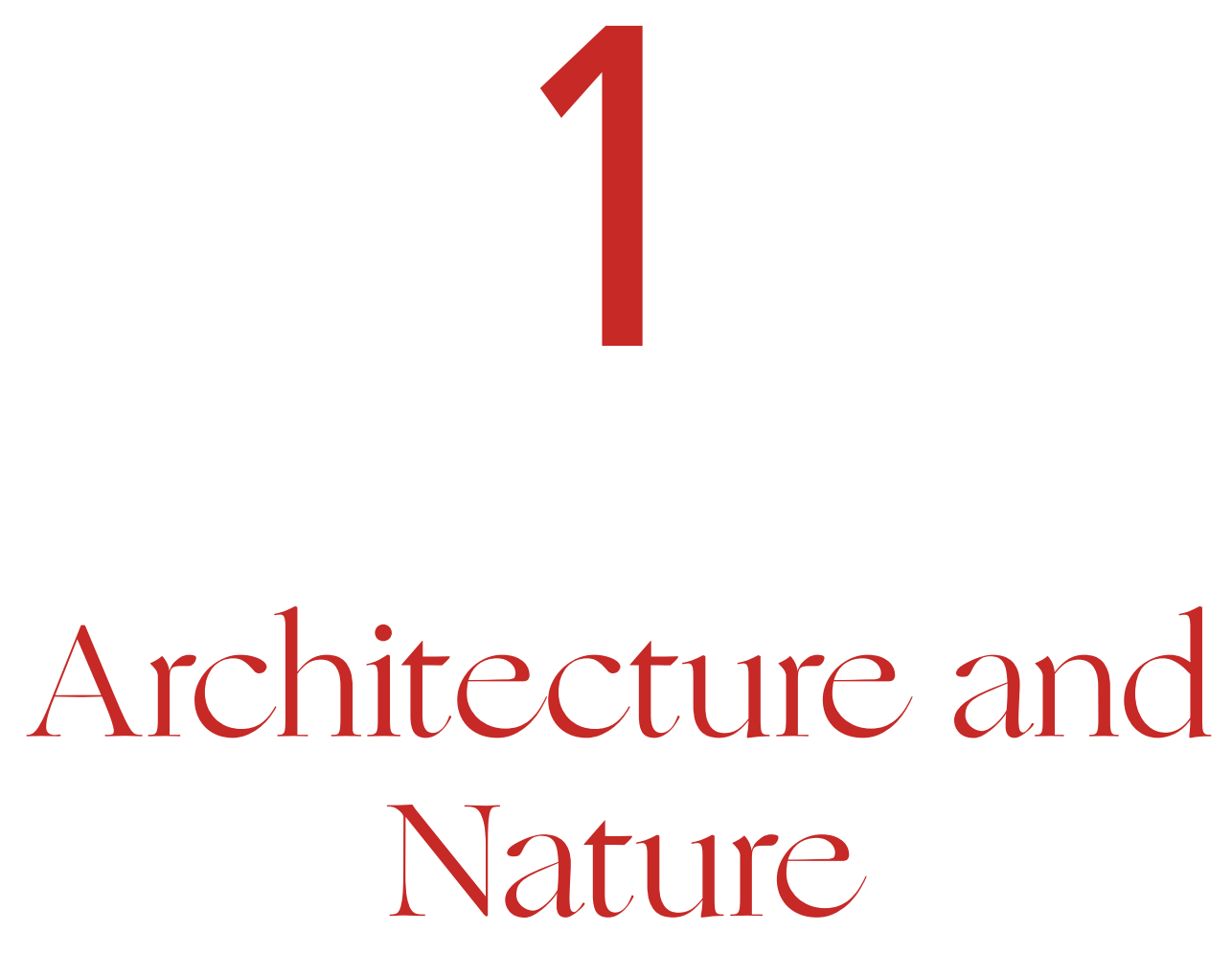

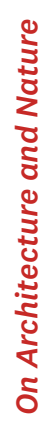



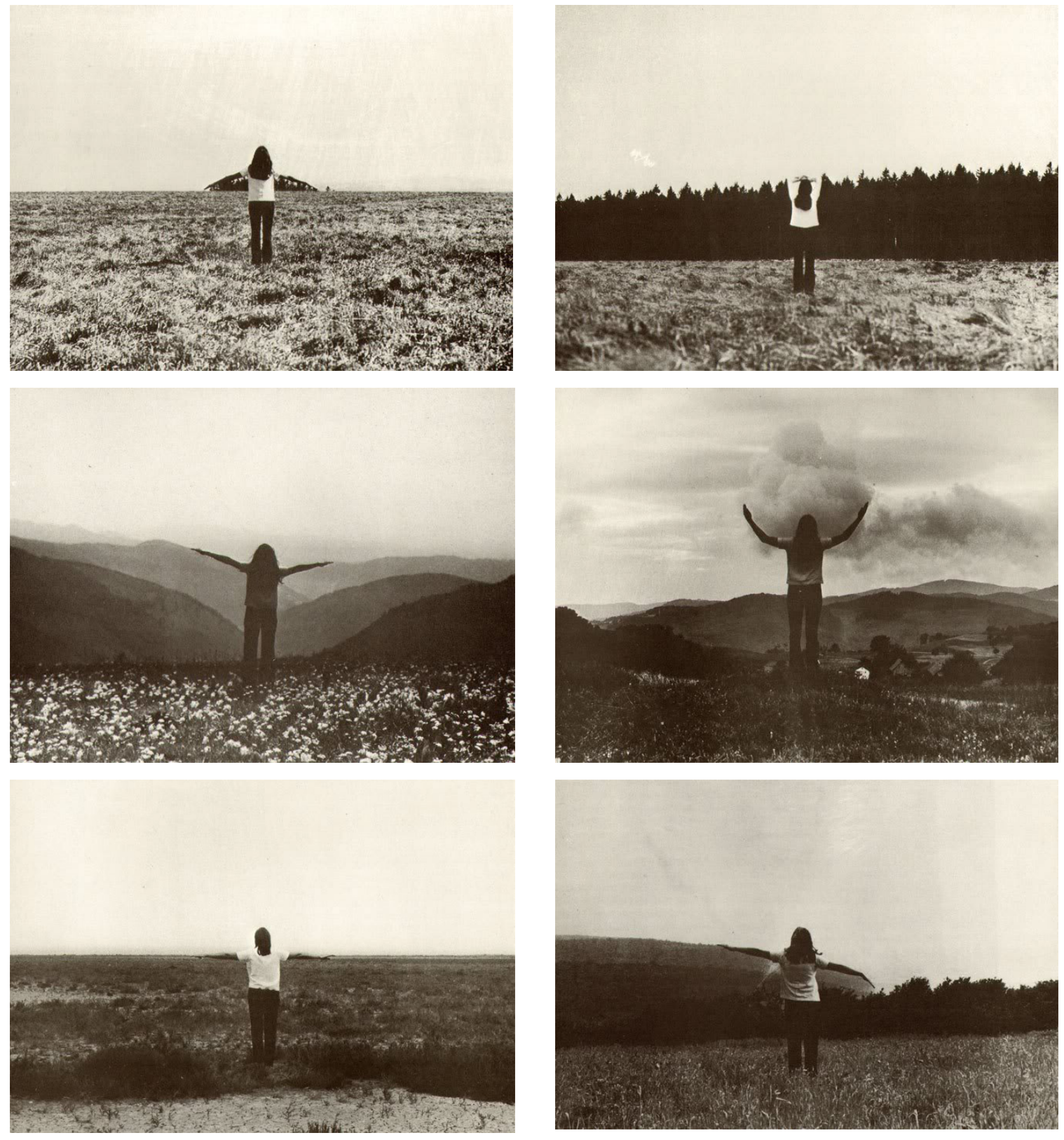


\section{Nature or Environment?}

Environmentalism in the Anthropocene

epoch presents a unique semiotic and etymological challenge to all those

affected by it, because it first requires that we define what the "environment" is, and secondly define to what extent our role in the environment needs to be modified. In the examination of various ecological manifestos, environmental agendas, climate change analyses and essays on nature, the politics of language reveal embedded conflicting worldviews. Raymond Williams famously breaks down

Intrinsic nature: the essential characteristics of a thing (the nature of social exclusion).

External nature: the external, unmediated material world (the natural environment).

Universal nature: the all-encompassing force controlling things in the world (natural laws' or 'Mother nature').

(Williams, 1983: 219) the origins of this issue with regards to the interlinked, overlapping and vastly different definitions of the word nature:

This pluralism has sewn division throughout the history of scientific, artistic, and philosophical thought. The resulting distinctions, inclusions, and exclusions have created schisms of all types and categories since the enlightenment. Schools of thought, artistic movements, religion, and the linked studies of human origins contest these definitions perpetually. The sciences of history, paleontology, and anthropology have likewise leveraged interpretations of nature to introduce new worldviews and at times aligned their findings with the political systems of oppression which held them aloft. The particular schism of worldview between human nature and a conceived external nature has enabled the commodification of species, geology, and even humanity. Critical theory still engages in this active combat across dozens of fields of 

research, and where many of the arts have grappled with identy politics, architectural theory still finds itself in a curious adolescence. Recent developments in the fields of cultural evolution (the socioanthropological branch of evolutionary biology) contest that contrary to previous belief that an extraordinary intelligence gave way to human dominance, the reality is far less deterministic. Joseph Heinrich's studies of failed European expeditions into inhabited, hostile climates (Henrich, J. P. 2015) make compelling arguments when paired with the timescale of the human exodus from Africa that it is, in fact, the construct of human society which has resulted in the Anthropocene. These findings undermine the argument for an individual strength unique to homo sapiens. Moving beyond the egotistical vision of the perfectly crafted species pulls back the veil on the contemporary scientific worldview. The intrinsic nature of the collaborative, social ape which learns cohabitation as a means of survival, places us in a much different philosophical position with relation to the environment than many of the worldviews of the industrial, capitalist society. In uncovering this subtle and connected human nature, an assessment of the way architecture has treated nature also comes into question. Certainly, an architecture of manifest destiny, stewardship, or the sublime must treat its contextual territories; its footprint and its design strategies itself differently from an architecture of the social human.

With Heinrich's conclusions, the time is suitable to retrospectively challenge the views architecture has presented of nature, as well as look forward to the possibilities that a new architectural interface might produce for the storied conversation with the planet and resources we thrive off. After a brief overview of natural influence in architecture, human history can be divided roughly and schematically around a single period wherein the politics of nature, art, and architecture within the public realm became inseparable. The 


\section{Romantic \\ Utopian}
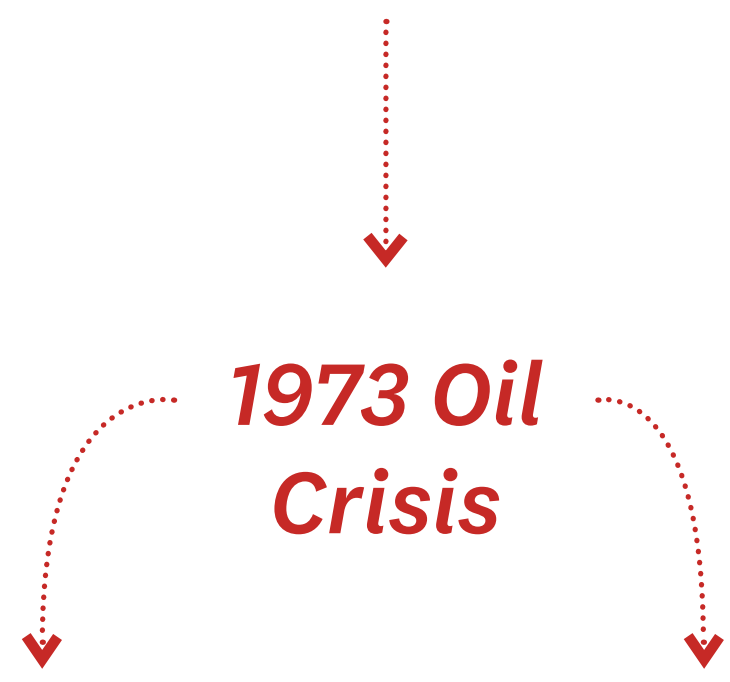

\section{Technocratic Socio Ethical}

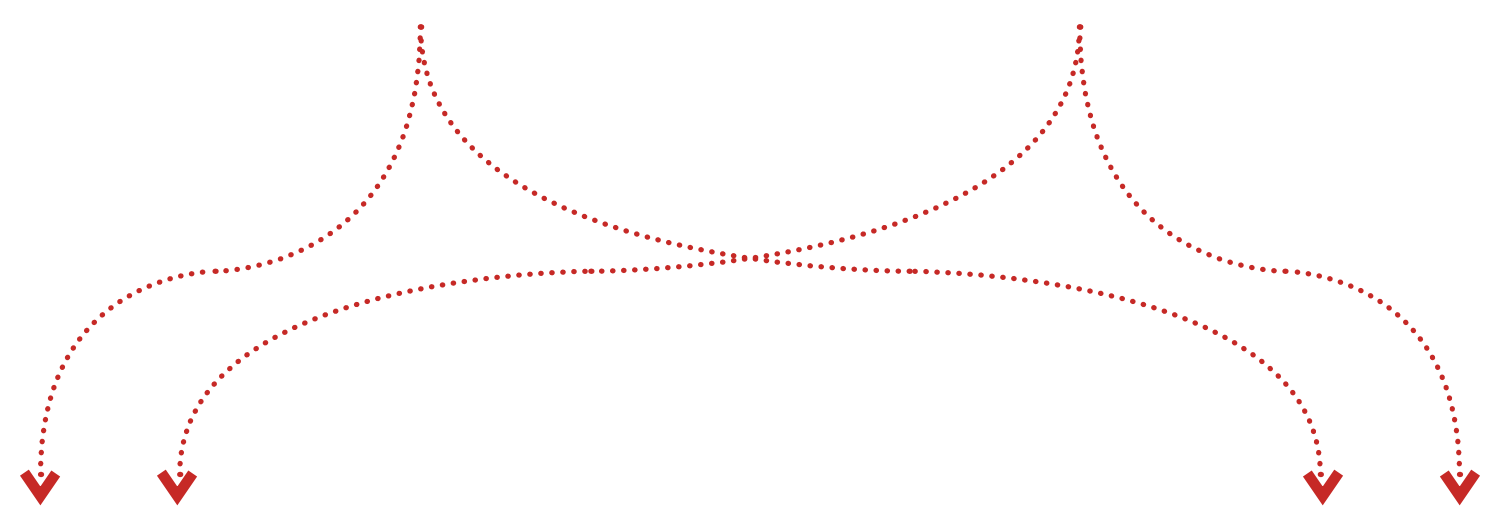

Actor Network Theory
Bruno Latour 
period surrounding the 1973 Oil Embargo brought to head the economic boons which cheap fossil fuels had readily supplied, as well as bringing into public consciousness the dependence of modern society on the systemic use not of natural resources, but entire geographic regions to support itself. This turning point solidified a rising cultural divide in 1960's and 1970's environmentalist thought. The concepts of a moral and ethical imperative for the safeguarding of nature and the planet, and the ideology of an economic, technologically based solution to rising societal demands for resources would result in a new balancing act which has defined environmental politics ever since.

Heinrich's revelations about social constructs, and the importance of this property of environmental thought can be traced through parallel analysis of Indigenous populations, exemplifying the potential for ecological balance based on societal beliefs. Many of the longstanding belief systems which contributed to ecological harmony and prosperity for all in these societies are being slowly echoed on the global scale, one specific example among the multitudes is the "Haudenosaunee's 'seven generations' principle. It has similarities to the modern international environmental principle known as 'intergenerational equity', requiring nations to ensure that their economic development does not compromise posterity's ability to enjoy a healthy environment." Another key factor, one which conflicts the most with the framework of the moderns, is the spiritual veneration of the natural world. The practice of spirituality in the cultural creation of land ethic, again understood in relation to Heinrich's work, acts not as a religious act, but in fact the distillation of years of observational data into praxis, reinforced through the same type of laws, driven by the laws and beliefs of the people, that drive contemporary environmental law. 

These laws come about through the examination of injustices on the environment, and the attribution of their impacts through the UN, or other governing bodies with the authority to impose restrictions, lawsuit, or preventative measure. The lawsuits and class action which govern large scale ecological justice in the contemporary field of preservation are driven by collective cultural impact and momentum rather than scientific consensus (Goodman, Thornton, Eno, 2017) and then extrapolated to international circumstances through precedence. "Global" thinking and climate action are inaccessible without the collapsing of any hierarchical view of these natural scales, because each potential natural asset to protect is contingent and co-dependent on the entire web of it's local ecosystem, the greater biome, it's ecoregion, climate, and the very atmosphere which protects it. Where mass agricultural and processes, due to the secularization of our view of environment, have no inherent social duty to the environment other than self-preservation, we now find ourselves searching, through law, to reinstate the protection which for much of human civilization, the laws of myth of and religion provided. 



\section{Land and Ethics}

The father of the science of wilderness management, as well as the creator of much of North America's "wildlife" systems and preserves, Aldo Leopold's one of the foundational theories he laid down towards the moral impetus to land management was the idea of the Land Ethic. The cornerstone of this ethical stance towards stewardship and coexistence is, rather than the traditional calvinist responsibility towards land as an act of virtue, that the long term inhabitation and care for land as Leopold defined it, including soil, plants, animals, etc, carried equal benefits for the humans engaged in the ecosystem. For Leopold the moral imperative however, is less strong than the way it is arrived at. His counter-pedagogical land ethic can not be derived, other than through a life lived in personal connection to the land. As continues to be one of the main tenants of wilderness science, the intuitive knowledge of the field cannot be subsituted by the telescopic, or satellitic perspective. This emergent, earthly quality of the land ethic is intrinsically tied to the inhabitation of space as one of the greatest forms of human vulnerability and empathy. In the case for a land ethic, Aldo Leopold implies a vital materialism, embedded in biota, and strata, which can only be acessed through passive phenomena and intuition. Deleuze would later explore these same ideas explicitly through the lens of cartography and language, but Donna Haraway's understanding of "worlding" expands on the ecological theme with greater accuracy. By weaving otherness and feminist theory into the ecological and scientific realm, Haraway exposes that the trouble of living ethically, on the land or otherwise, comes from an intersectional entanglement of a great variety of specific differences. Whereas Leopold, a park ranger during a time before American wilderness dwindled, found his land ethic to be inevitable, Haraway speaks specifically to the complexity and obscurity of the construction of such an ethic in the anthropocene. 
wave

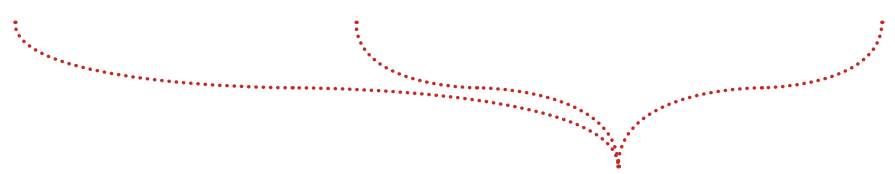

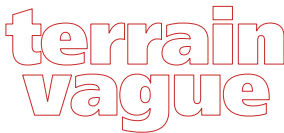<smiles>[CH]1CC1</smiles>

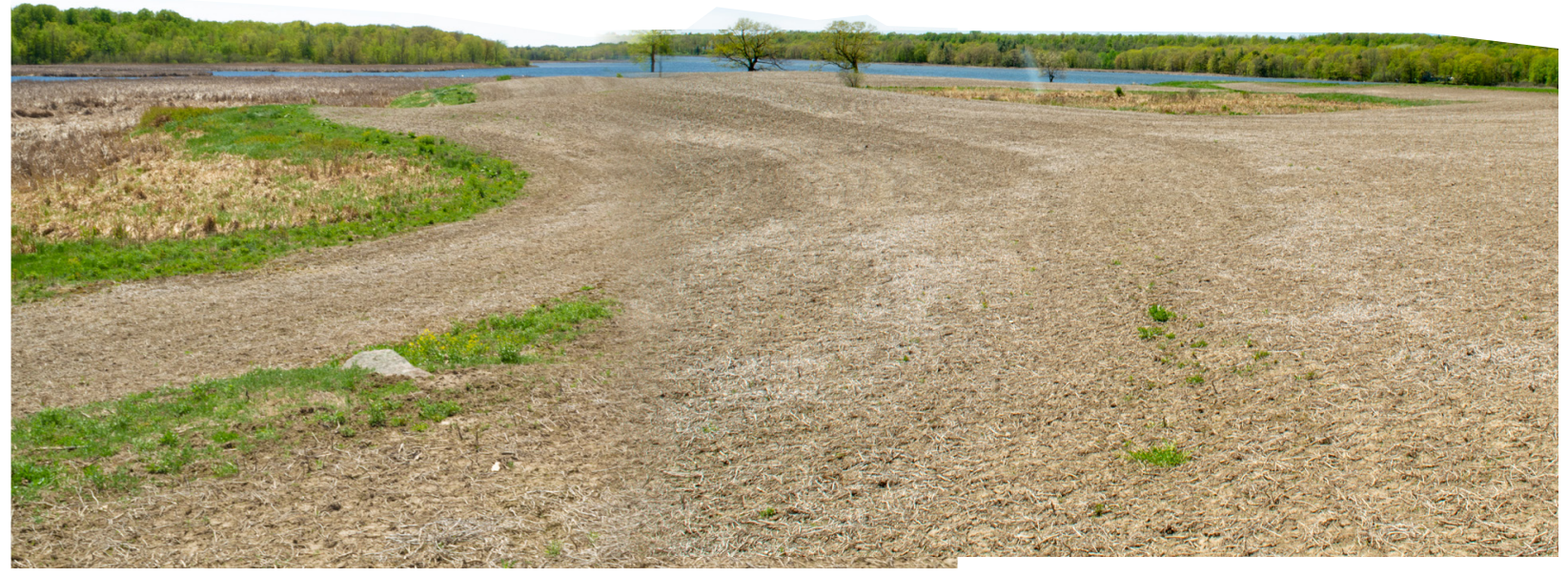




\section{The Terrain Vague}

A French turn of phrase with complex etymological backgrounds, "wave land" which denotes pastures set aside for viticultural production, spaces in the countryside which exist somewhere in the limbo of nature and production, often noted by the rows of planting which stretch in wavelike forms across contoured countryside. In 1995, Ignasi de Sola-Morales reconsidered the use of this term in the urban context, with it's vagueness also indicating the interstitial between organic and inorganic processes, the leftover threshold between the constructed and the emergent. The visual banding of the countryside in the absence of ecology, similarly to the leftover spaces, the alleyways and courtyards and mishapen voids of the city, contain a visual power to excite the eye. The connotations of vacancy, emptiness, and the inherent estrangement of these spaces from the order of things around them, whether it be the cosmopolitan language of the urban fabric or the natural ecological hierarchies and cycles of water, carbon and biota, pose an inherent aesthetic and ethical dilemma. The sense of refuge from the traditional order and it's potential for fluctuation generates power in an image precisely, Sola-Morales says, because these fallow urban and rural sites an intensely uncanny. The liminal quality of the disruption of productivity is both a reprieve from the modern machine for living, and a reminder of it's omnipresence.

The anthropocene provokes a reconsideration of normative practices of urbanism, as it becomes clear that even the most remote land is formed by its relationship to our geologic force. What Sola-Morales called the terrain vague, spaces of modern brutality and evironmental irresponsibility in the urban have expanded in meaning to encompass the globe. The triple signification of the french vague, wave, vacant, vague, have now taken on new meaning through our agricultural and geological productions, and the waves of monocultured soils. 

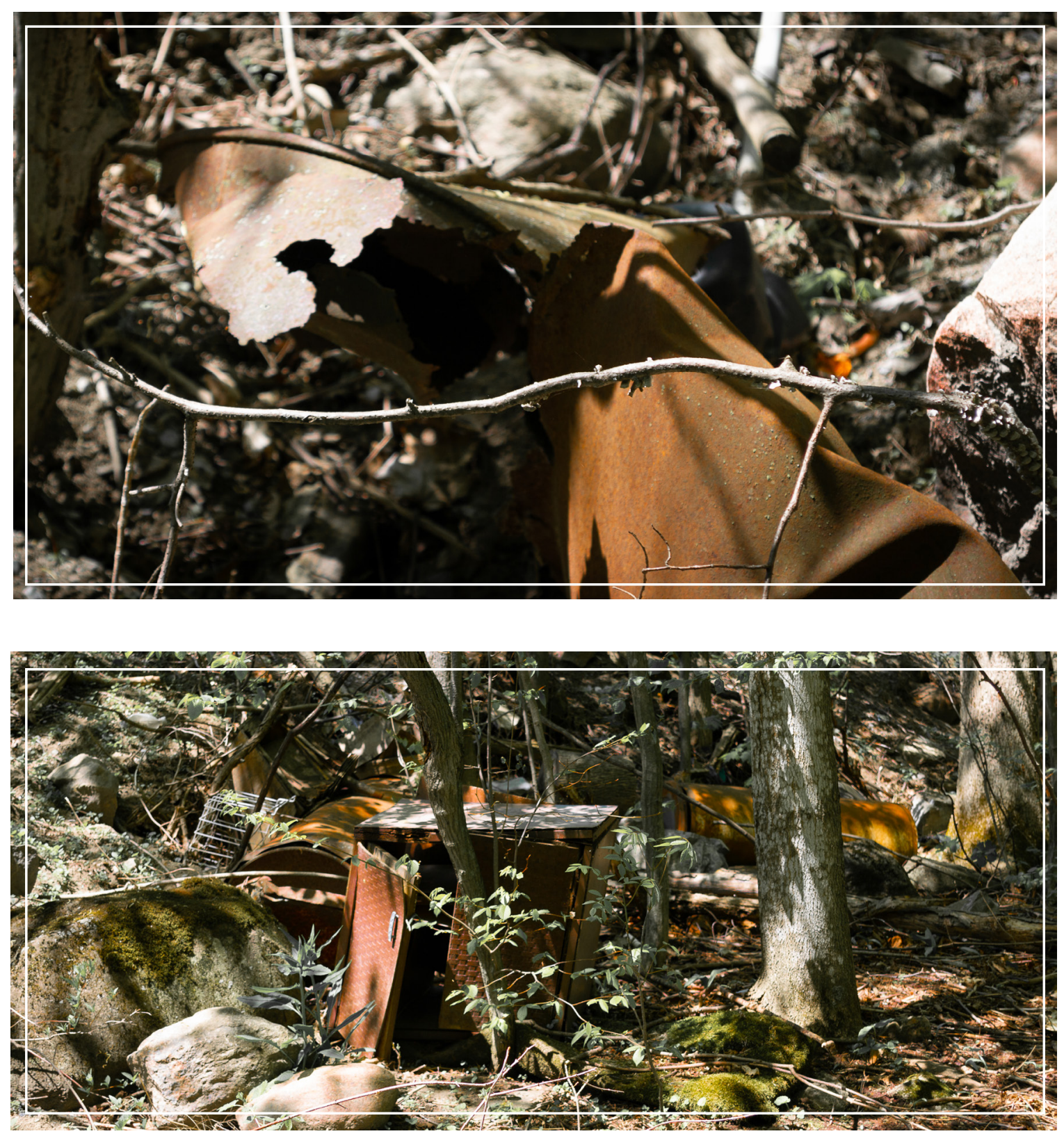


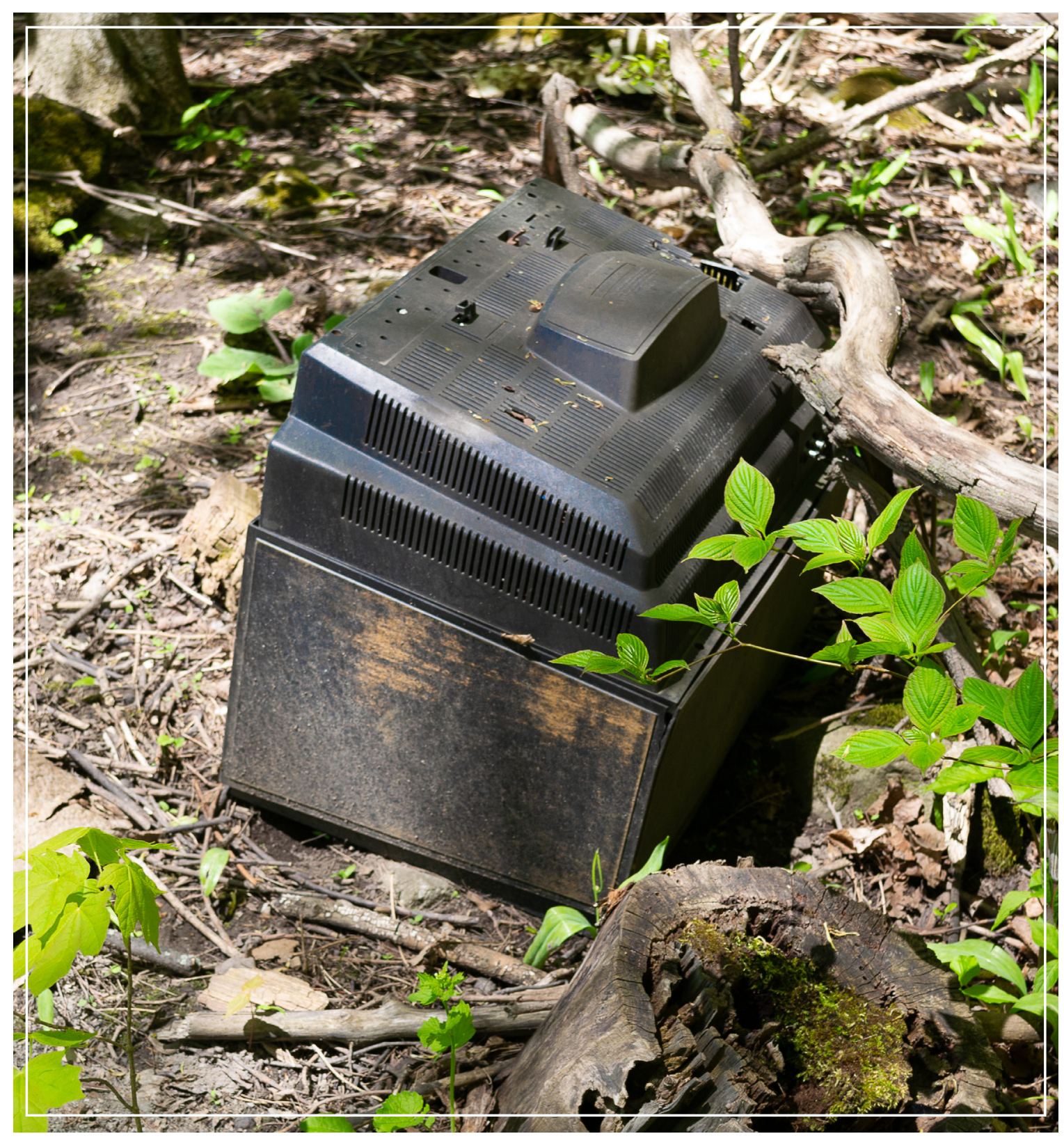

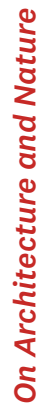




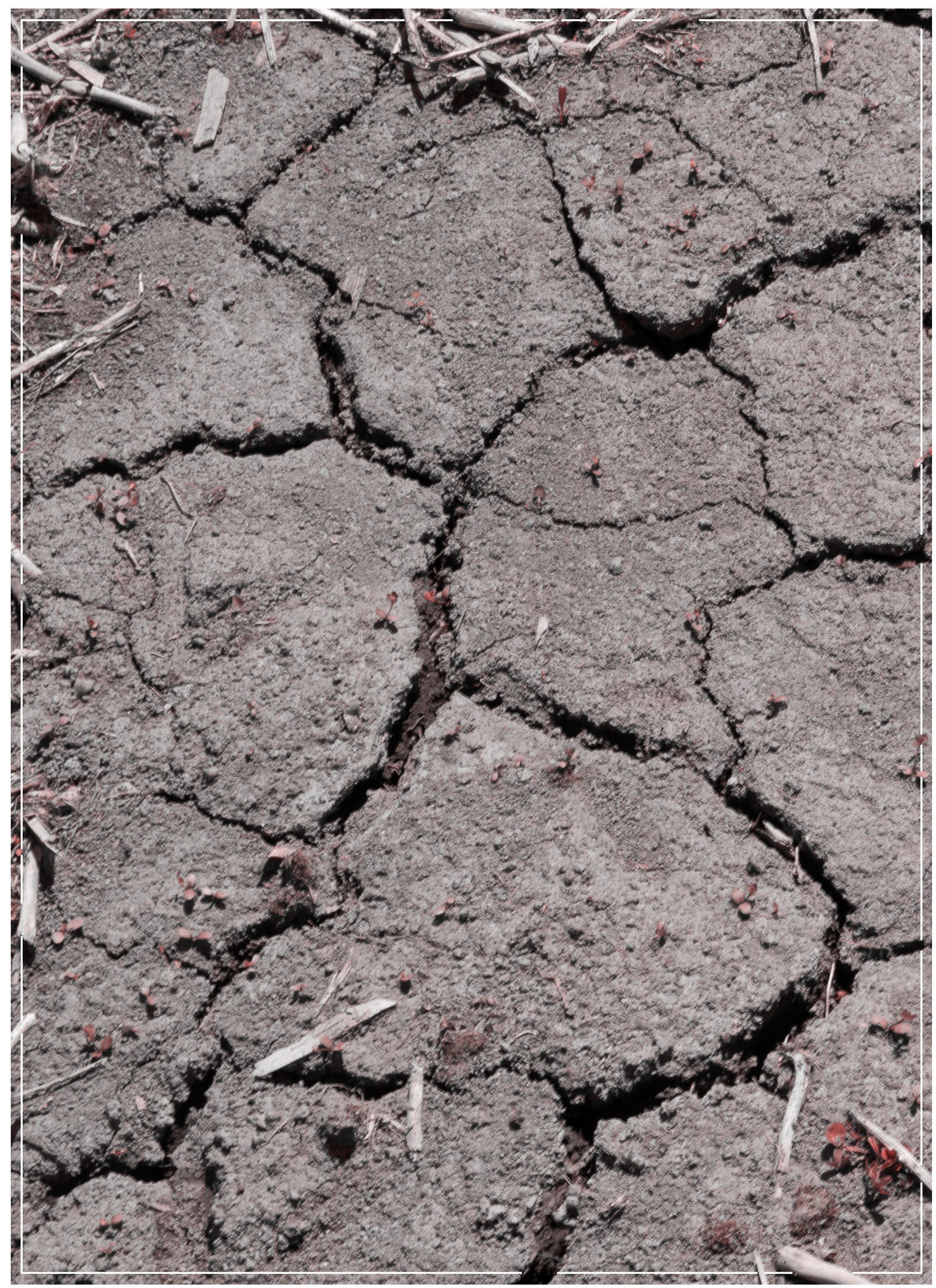




\section{The Pallid Soils of the Anthropocene}

These unincorporated margins and voids, the un-inhabited and un-productive spaces are no longer mere constituents of urban back-alleys. Instead, the expansion of the human cosmos to consume the globe has also rendered our landscapes, each previously unclaimed space accountable for some productive potential.

The Johnson Bay Wetlands are a site of agricultural, monoculture farming which have caused a once fertile tract of land, in a nationally designated wetland of scientif interest to, through human mismanagement, become near barrent. This provides an opportunity for a restoration project, on land who's "economic" value has been all but extracted. Can Architecture, and the creation of space not only rejuvenate the land that has been stripped, but in the process, also engage all those who visit and use the land in acknowledging the tragic voice of this land? The following images show snapshots from the Johnson 


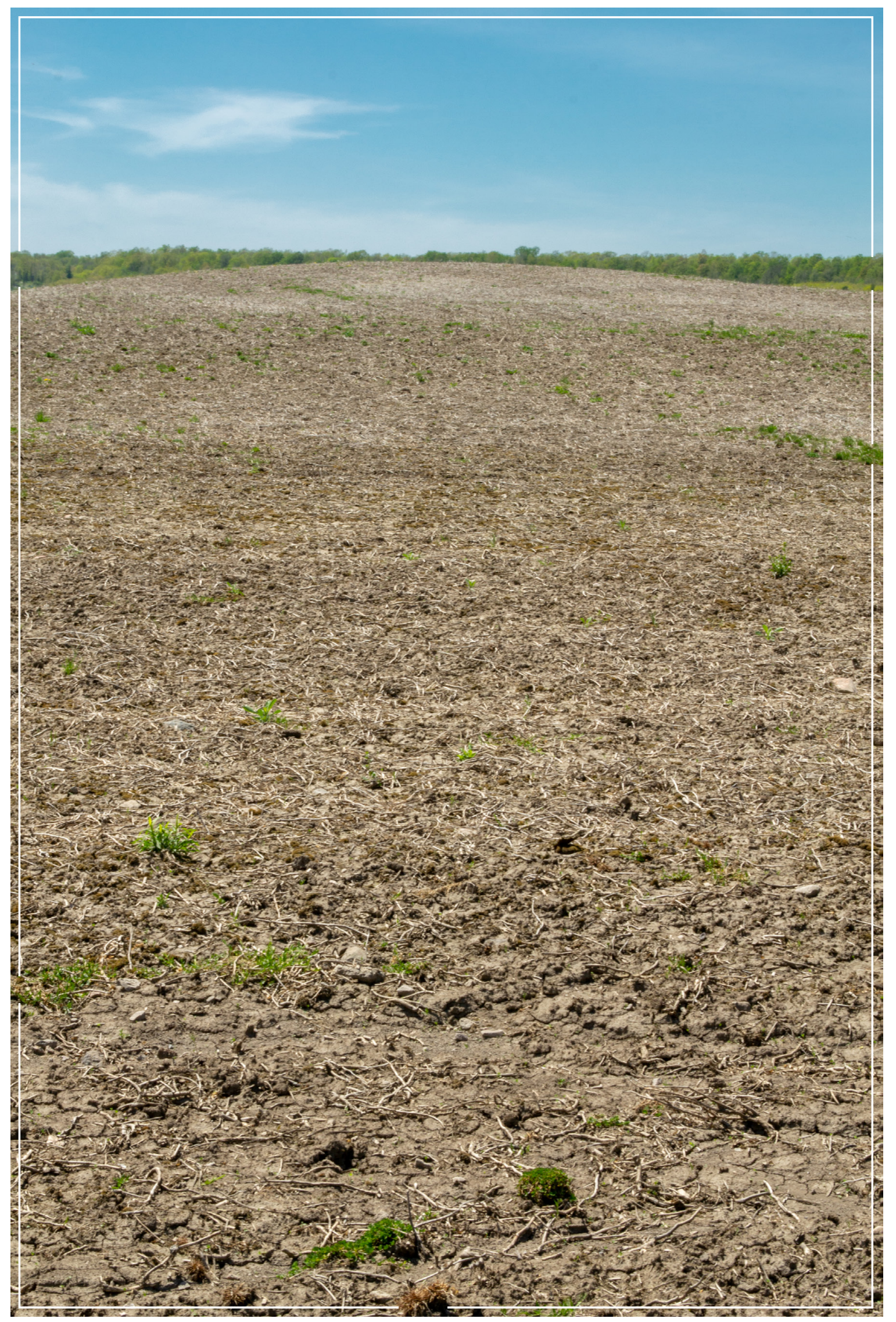




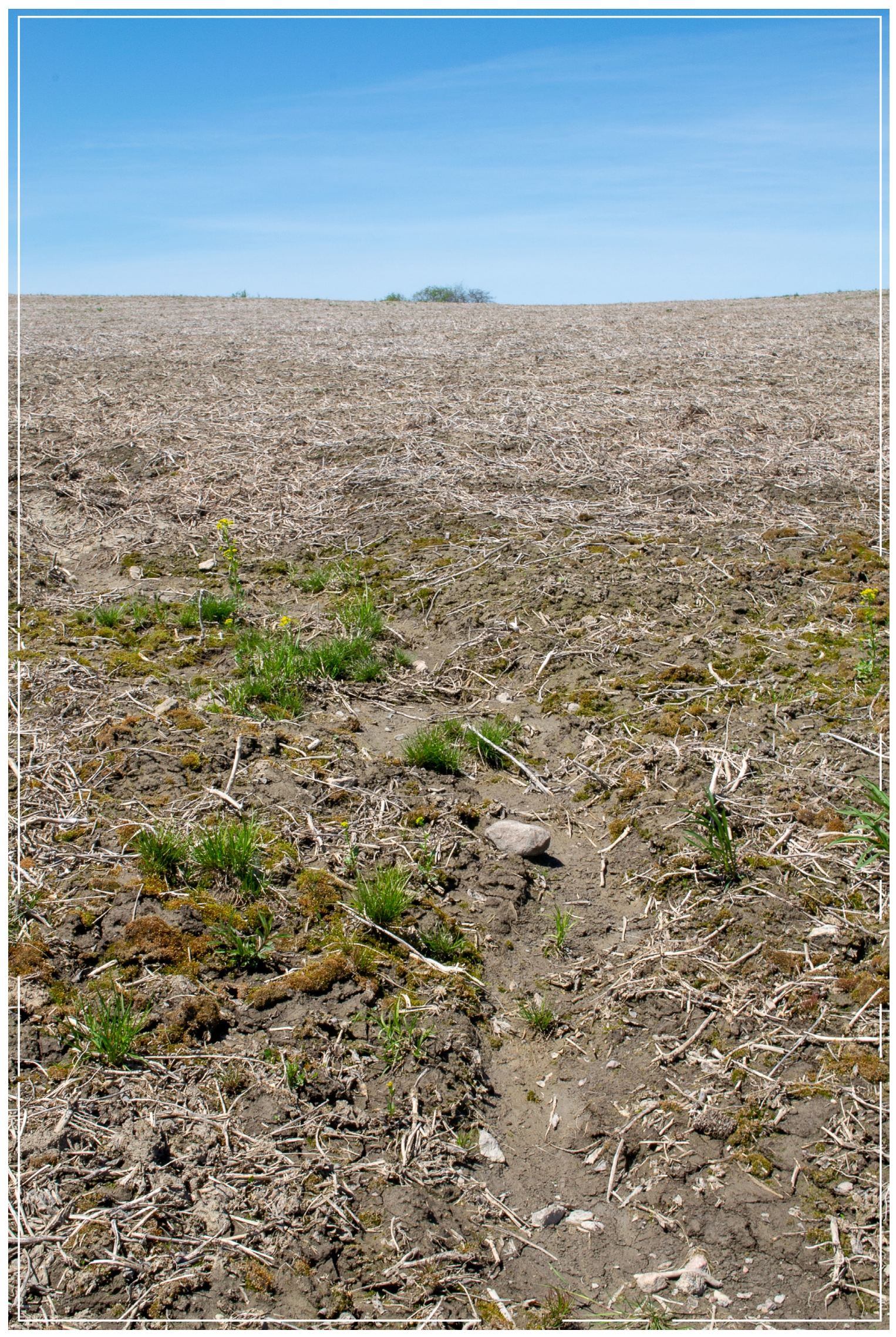

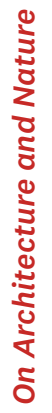



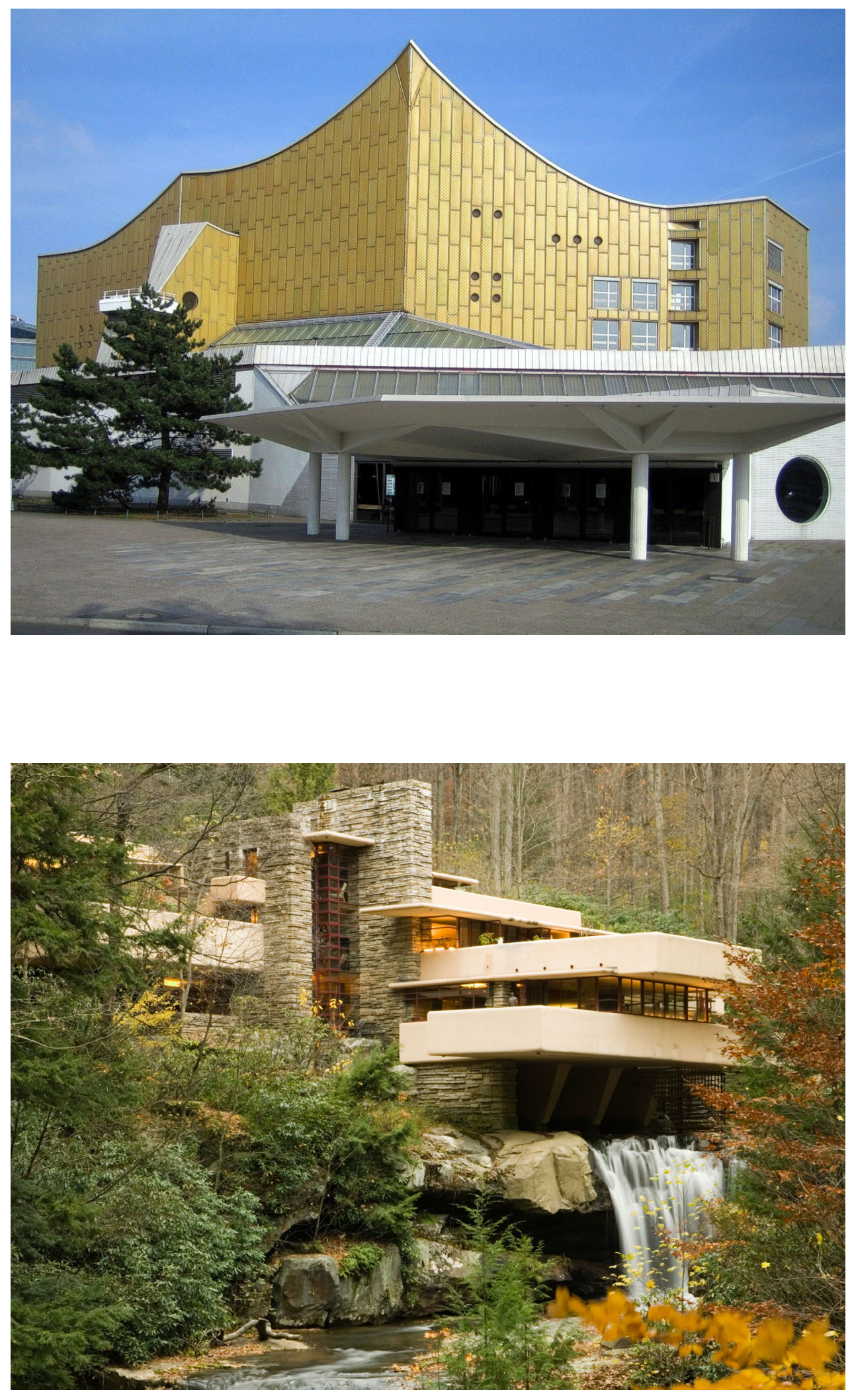


\section{Organic Architecture}

The most prevalent influence of nature on architecture is as indirect inspiration. Generally seeking to create harmony, and compatibility with nature, Organic architecture often uses influences such as curvilinear forms, material palettes, and the design principles of contrast. Organic architecture is generally accepting of a distinct philosophical difference between the built world and the naturally occurring world. In understanding organic architecture, one has only to understand the formal links to the nature, the shapes, patterns lines, curves, and influences from which they are derived.

\section{"The straight line belongs to men, the curved one to God." \\ Antoni Gaudi}




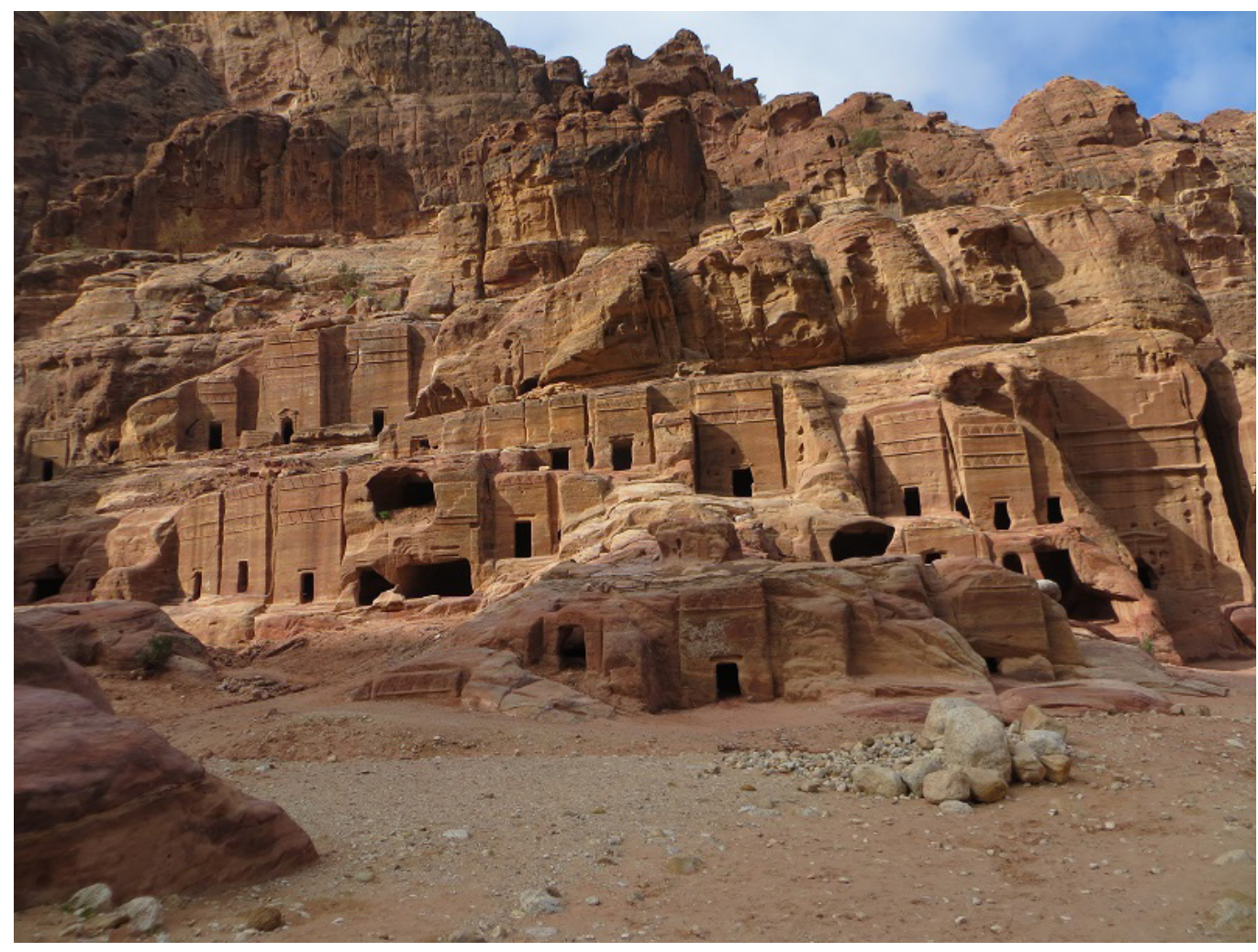

Figure 4: Petra Cave Dwellings

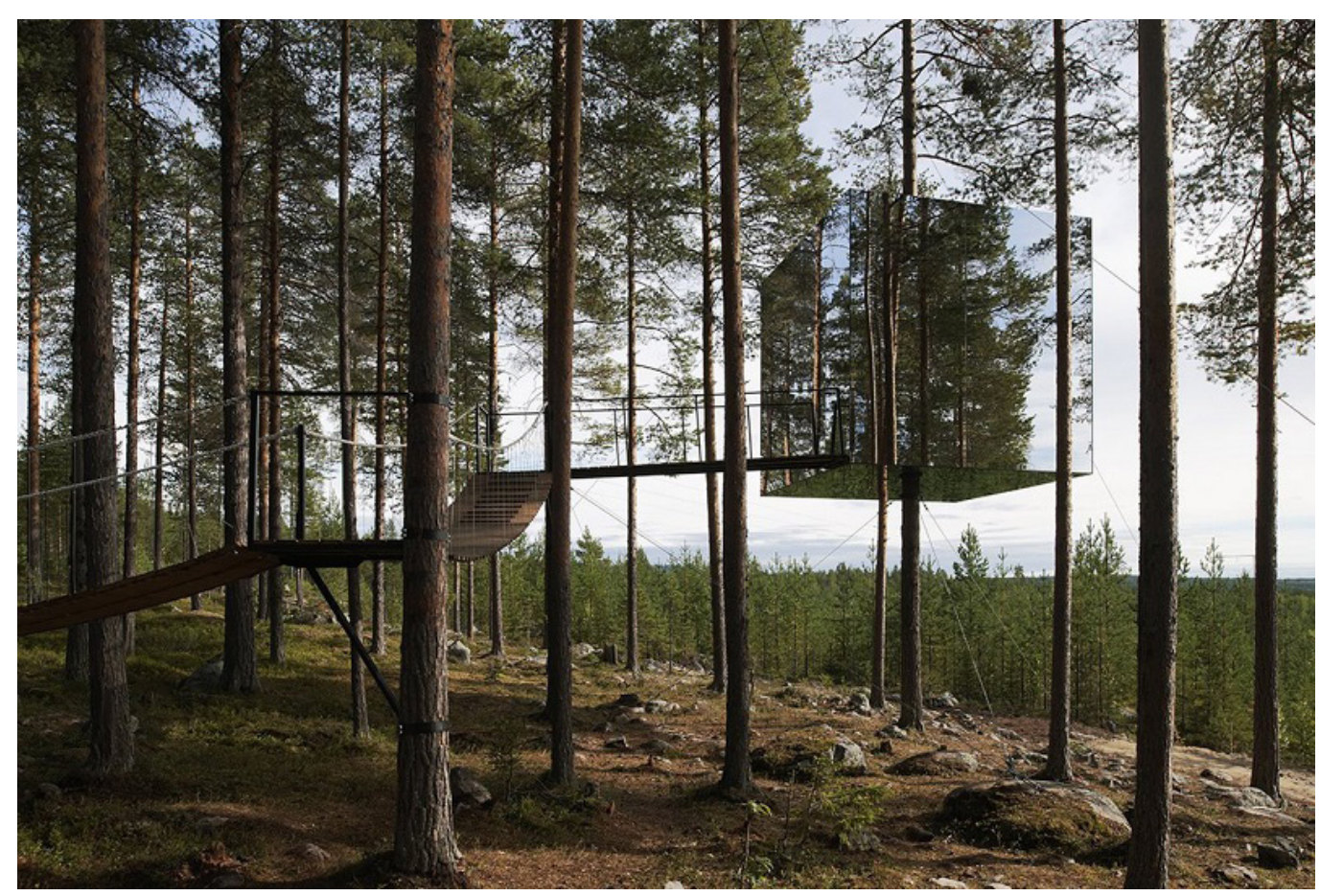

Figure 5: Tree Hotel by Tham - Videgard Arkitekter 


\section{Invisible Architecture}

The branch of architecture here referred to as "invisible" architecture is based on a strategy of minimal interference with nature. Whether by abstaining from additional ornamentation in the case of excavated dwellings, or by attempting to conceal itself in it's environment through camouflage, invisible architecture is an attempt to limit the interaction between the built realities of architecture and the wilderness. This seperation is based on the idea that the very presence of architecture or human influence mars, spoils, or otherwise alters spaces which would otherwise be considered wild. The ethos of the boy scouts organization, to take only pictures and leave only footprints, is the essence of this idea, that a respect for nature involves the removal of human influence and an often laissez-faire approach to conservation can be an unintended result of this attitude. In the terms of the global environment however, this philosophy is unrealistic in the anthropocene era. While containing a great formal, design and aesthetic value, in a time where human influence is exertted across the globe, the attempt to leave spaces as they once were as a method of conservation contains troublesome implications that it is evern possible to return to a world in which human influence has not already garnered such destruction and change. 


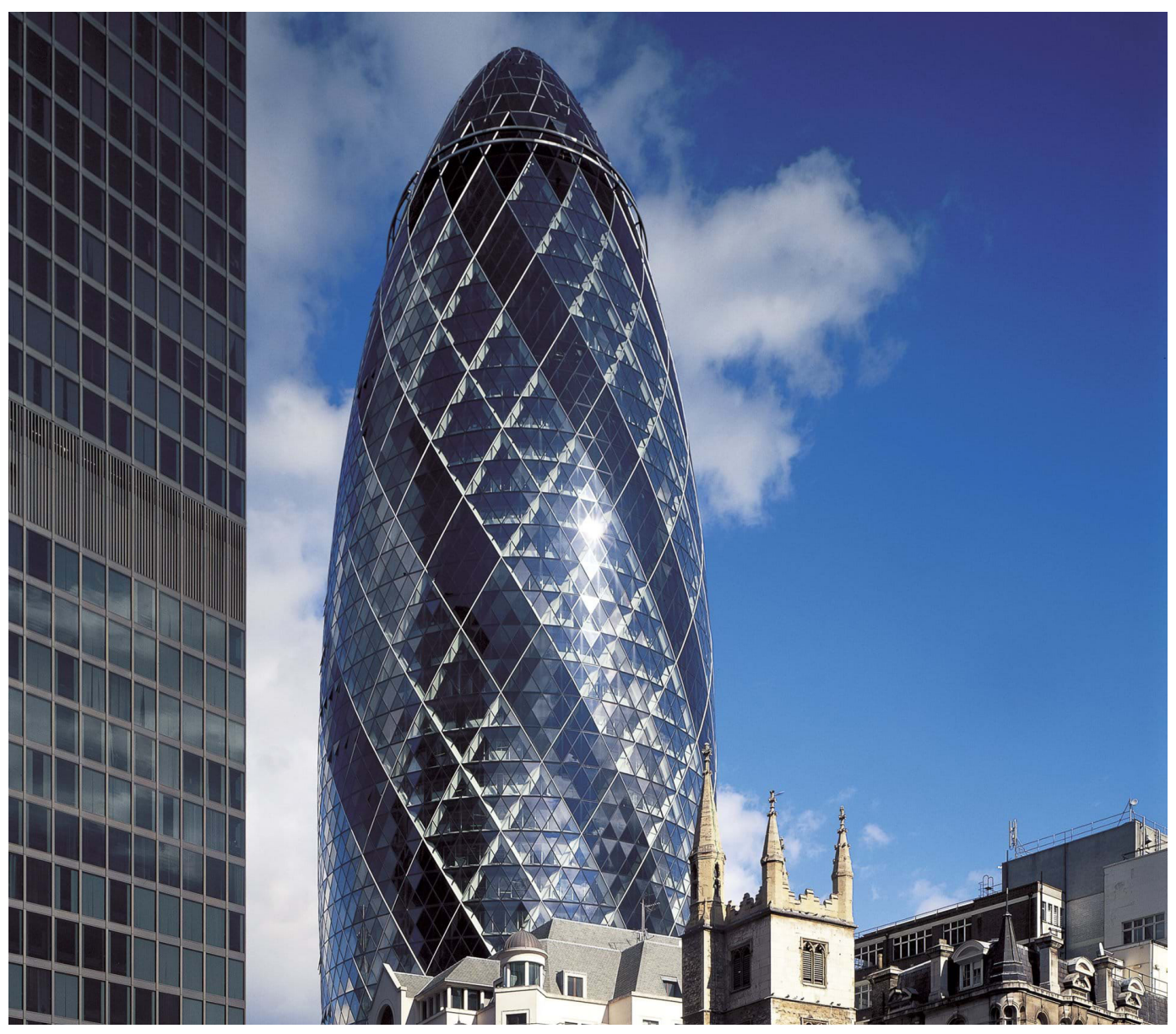

Figure 6: Gherkin Tower - Norman Foster

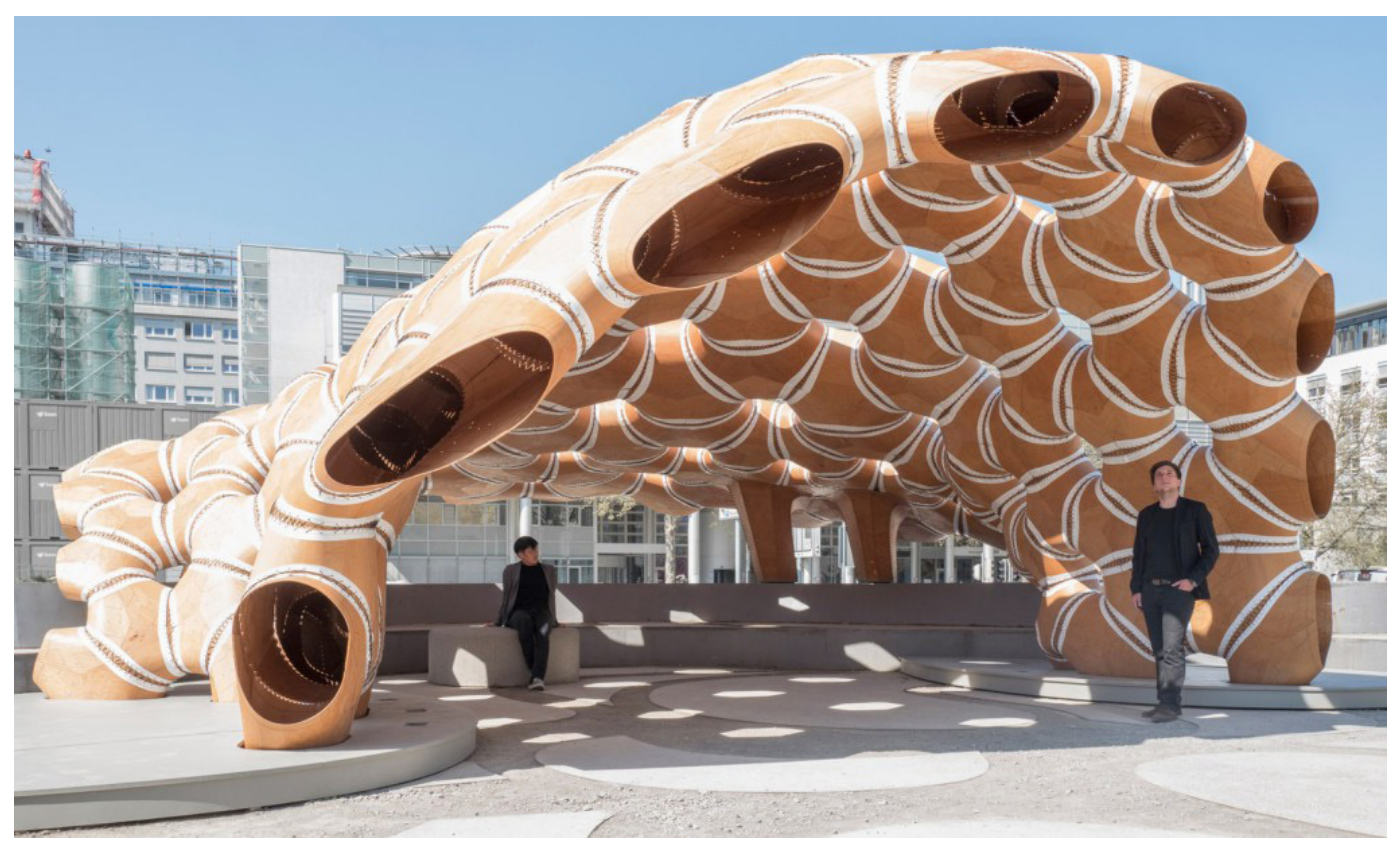

Figure 7: ICD/ITKE Research Pavilion - University of

Stutgart 


\section{Bio-Mimetic Architecture}

Bio-mimetic architecture is based on the technological and intellectual extraction of the innovations of nature and the implimentation into the structure of building and the language of design, This process, although long-standing in the profession and various forms, concerns considerable shifts in philosophical stance to that of invisible and organic architecture. The understanding that structural systems, even those composed of concrete and born out of human intellect, are bound by the same physical laws as molecules plants and bones enforces a view that architecture, although difference in many ways, is inherently a part of nature. 

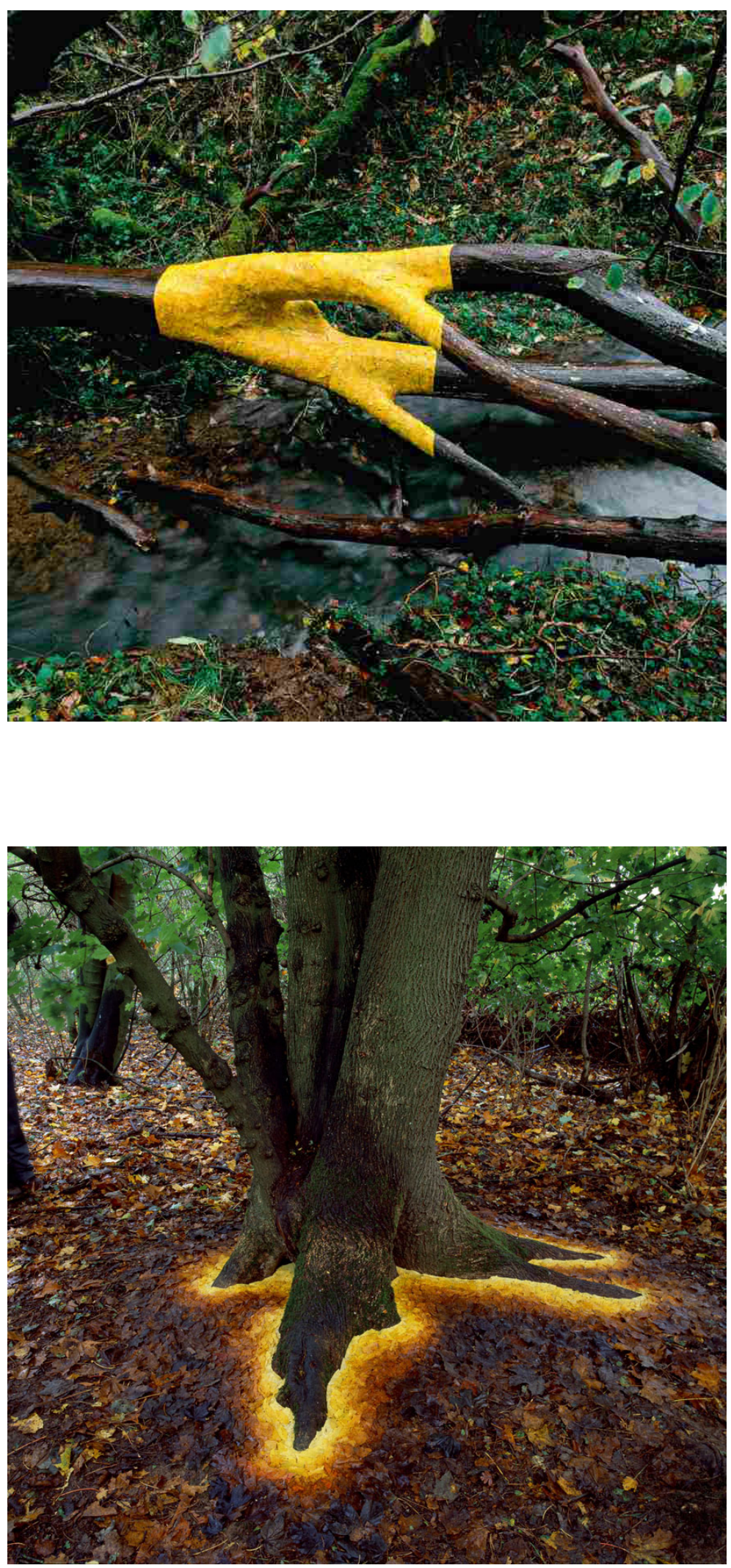


\section{land art as cosmological link}

As an experiential practice, and one where inhabitance and participation are key, simply applying laws of nature to architecture fall short of any attempt at a true dialogue with environment. The complexity and scale of a true, universal "nature" marginalize the capacity of static forms of communication. In each of these preceding examples, architectural design harnesses ideas of nature, but always reinforces an understanding of the human as synthetic. Intuitively an instrument needs an operator, but in fact this apparent role is actually composed of two discrete actors in the process, the calibrator and the viewer. If the architecture is the instrument, and the architect the calibrator, then the instrument will continue to read and synthesize its data regardless of a viewer. Without the viewer, the data still exists, but is never recorded.

The tools through which the architect can bridge these worldviews of nature and building can be extrapolated from the
American Land Art movement. From this and its associated earth works movement we can find origins of the principles of the instrument, principles of environmental advocacy, principles of creating a voice for the other, and the active dissolution of the barriers which hide the rhetoric of art, the environment, and science behind the closed doors of policy makers, galleries and laboratories. The response to the perceived objectification and commodification of art was to bring the conversation into the territory of the subject. The works of Robert Smithson, Michael Heiser, Nancy Holt, Andy Goldsworthy, and all their contemporaries fought against the scale of experience which much art had become accustomed to. The resulting works simultaneously placed their viewers and participants on level footing. The scale and pattern of human interaction in these works in turn reflects closely the result of masterful execution in architecture. The connection between the detail and overall form is evident, and this connection results in the 


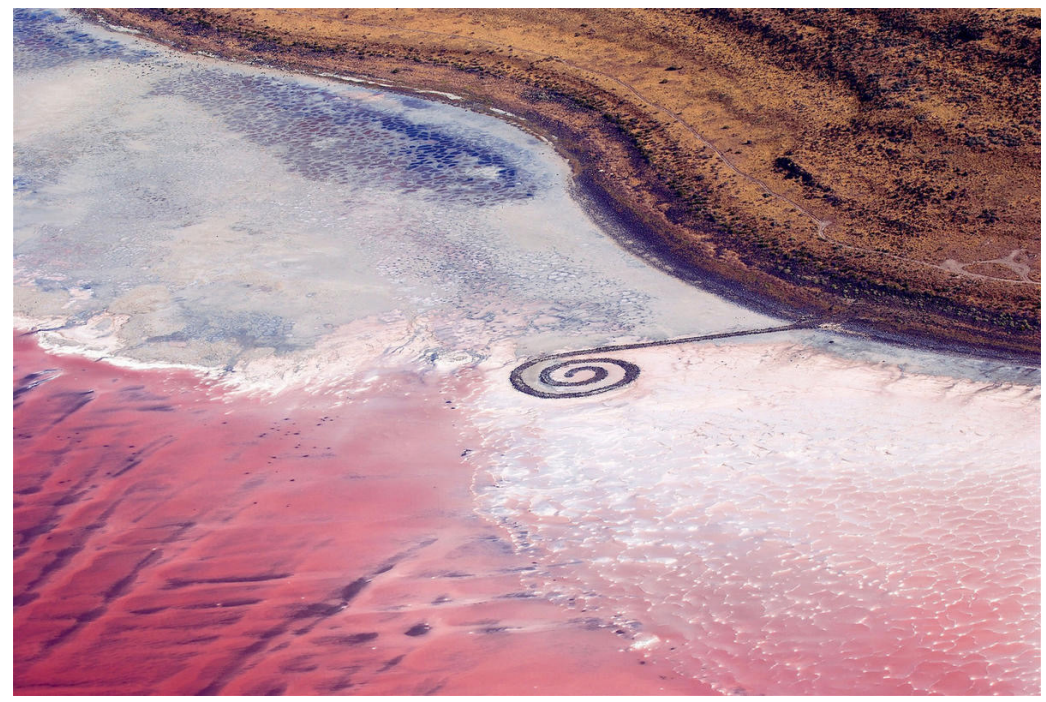

Figure 10: "Spiral Jetty" - Robert Smithson

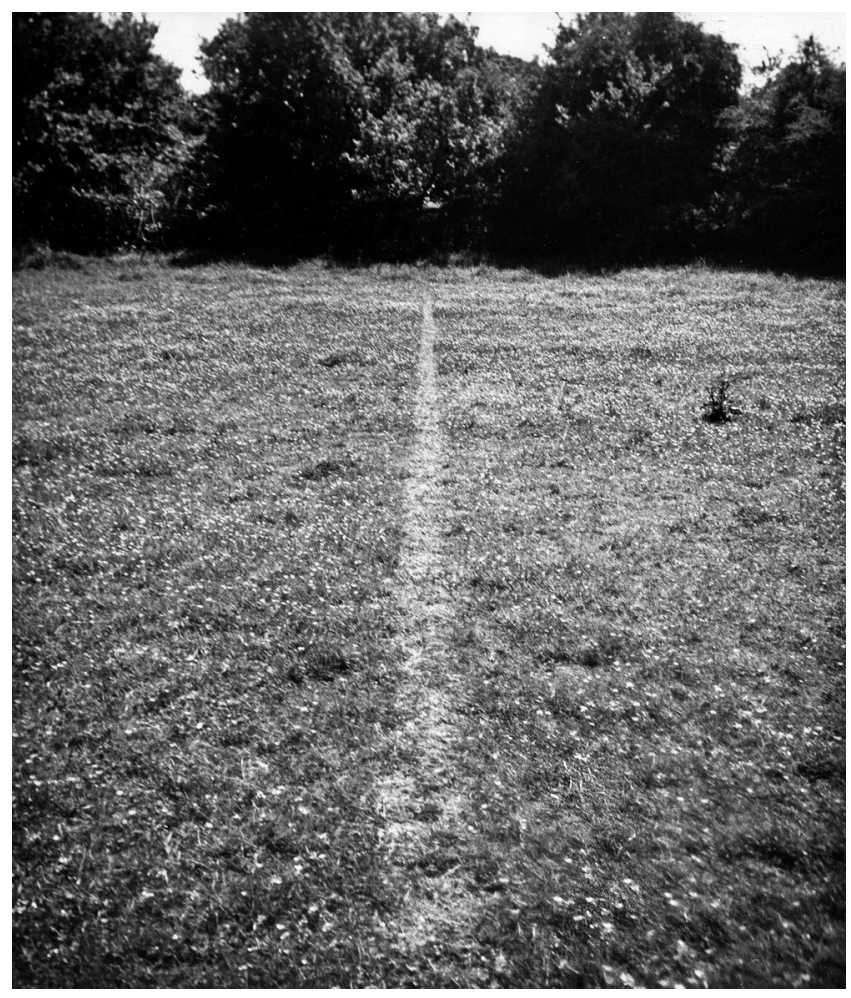

Figure 9: "A Line Made By Walking" - Richard Long 
elevation of the senses and experience beyond the mere inhabitation of space. Here, material execution, procession of entry, site relationships and the neighboring context are fundamental to the work. Embedding the intellectual dialogue of the work into the acts of the human body and the traits of the site is the land-artists true response to the state of both art and society at the time. Art as a self-contained experience removed the intellectual, financial, and class barriers which they argued had caused a stagnant, isolated and self-congratulatory art world, and invited everyone to take part in the discourse. The establishment of this experiential link was integral also to the environmental message they delivered. Upon a close reading, Spiral Jetty cannot be experienced without entangling the participant and their actions into the Salt Lake in which it resides. By engaging with the Jetty, the human experiences the crunching sound of salt underfoot which they have produced, walks the processional spiral only out of the innate desire to do so, and observes the changing qualities of the water only through their own observation. Despite being a piece of work that is intrinsically tied to its environment and site, it is only through the interactions of the viewer that it becomes art, and thus states that the environment is not distinct from the user.

. in the same way technological debates of the environment have similarly gained social capital without gaining the voices which lead to political change. 


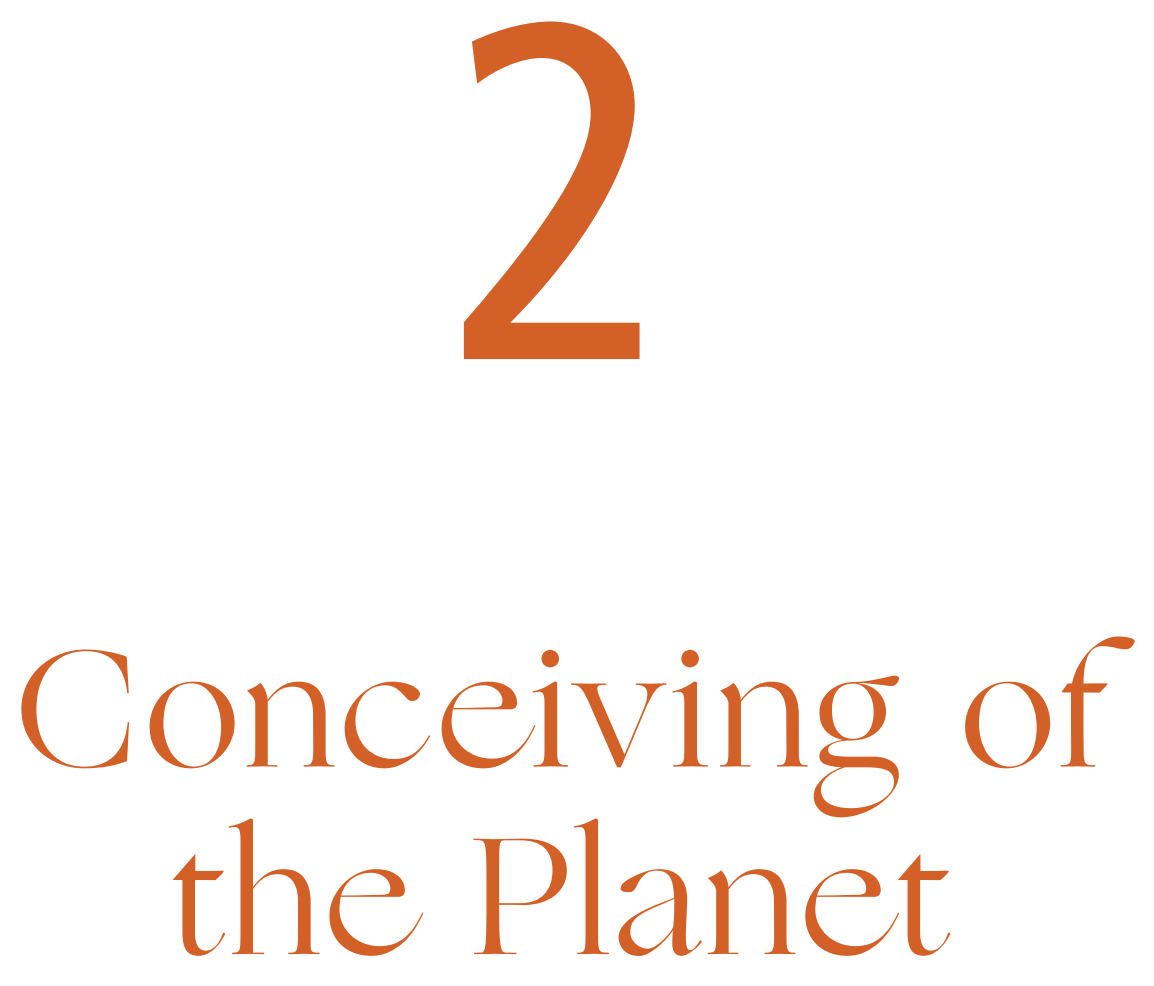

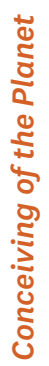




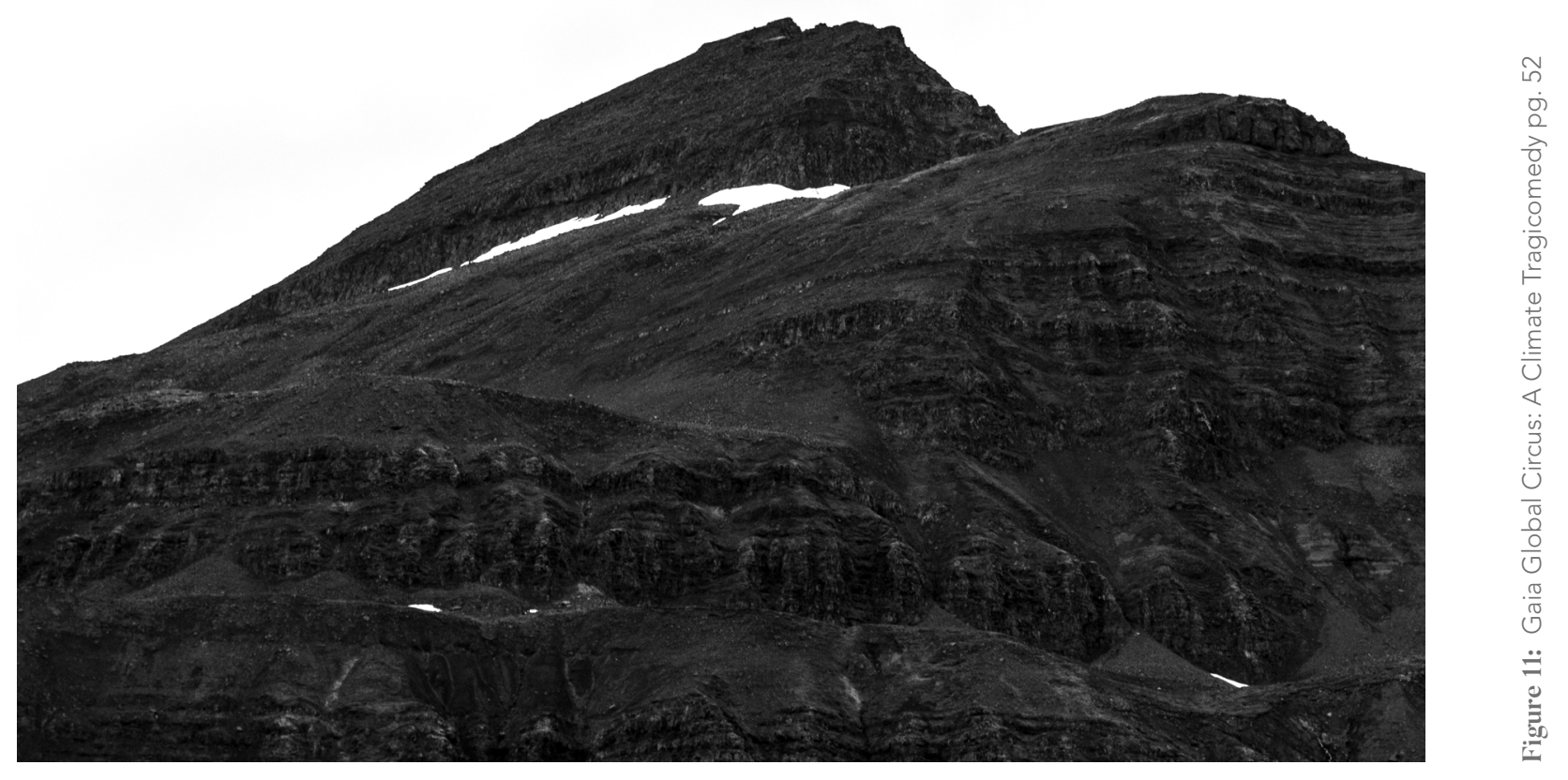




\section{climatic imagination}

The distinction between environment, climate, and surroundings present a struggle and barrier to any thinking surrounding ecological and global conception. Whereas the body passively constructs a surrounding built sensorially, the climate is innately non-intuitive. Climate as a concept must be fundamentally and intentionally constructed, out of statistical averages and time frames which, upon varying and selection, can vary broadly. At once constant and in total flux, the instan $\neg$ taneous reality of the individual and the slow realities of statistical average create a divide between our species. Despite attempts to rasterize, bridge, and define it this gap is impossible to close. Any concep $\neg$ tion of the planet, the changes which it is going through, and the process by which humans have entangled themselves into those changes remains an instantly impossible concept. The only feasible response to this is the active development of networks and fields of knowledge, and this response is vital for a variety of reasons. As outlined previously in discussing the works and studies of cultural evolution, with particular emphasis on the works of Heinrich, we find that not only has the Anthropocene epoch probably come to pass primarily due to the ability of humanity to develop networks of knowledge on a scale to rival Gaia itself, but that this human 'nature' contains our best options for dealing with the issues posed by a rapidly changing Gaia. Fostered empathy and community through storytelling, language, and mythology which empathizes with and humanizes actors both within our rational set of knowledge and beyond has allowed small groups of human settlements to deduct and respond to scientific phenomena which are still being modelled and explained millennia later (citation needed, Heinrich). In Bruno Latour's project 'Gaia; Global Circus' the French philosopher points to the critical failure of contemporary scientific bodies of knowledge to do exactly that which has been intuitive for millions of years of 


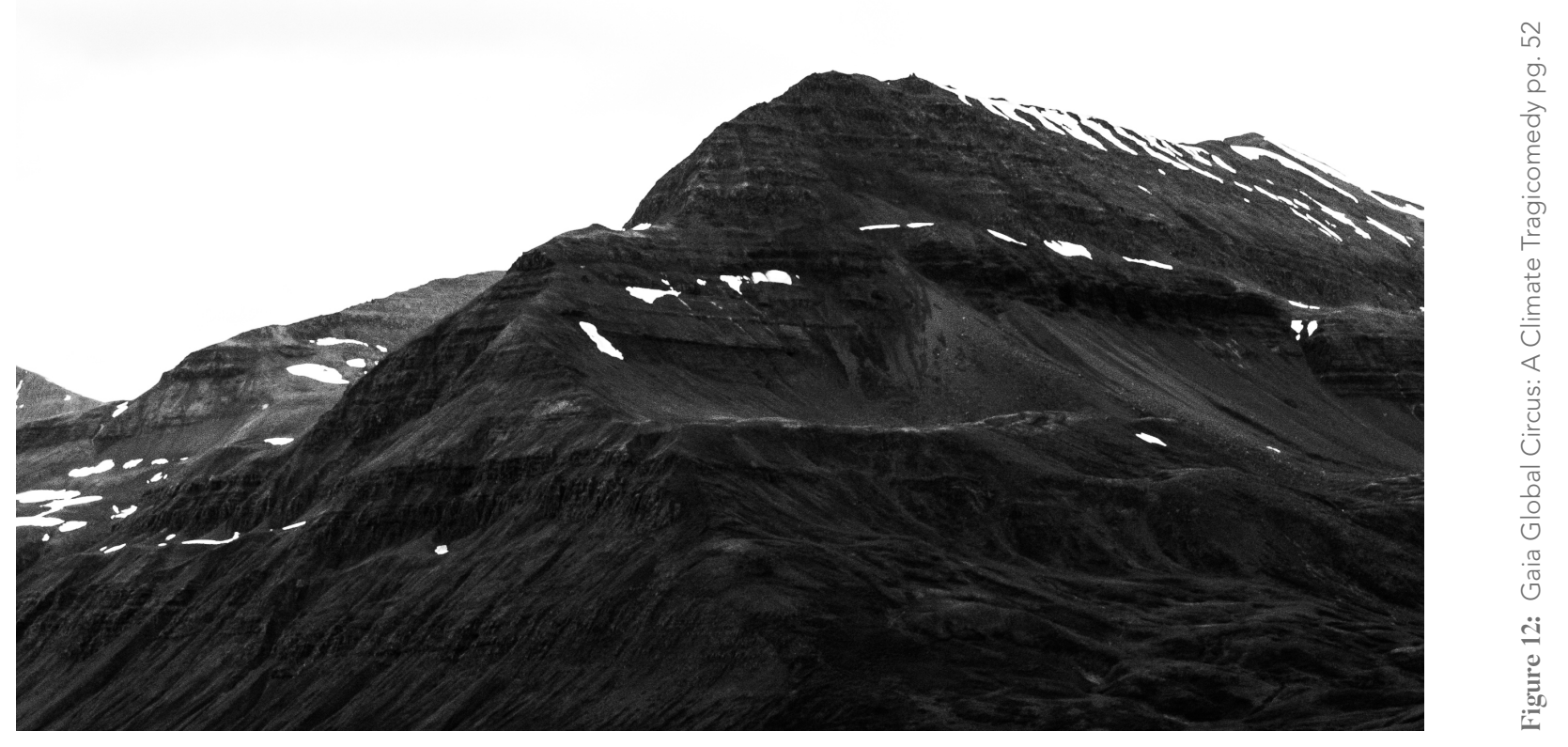


human development. To use narrative, storytelling, and art to render newfound knowledge as actor agents, specifically, that of the planet. In their review and expansion of Latour's body of work, Ghosn and Jazairy call to our attention that, alongside his own body of writing and thinking on modes of existence, Latour's theatre project embodies most clearly his metaphysical machine for representing the summation of data through which we view our planet. $\mathrm{He}$, in turn, asks the audience members not just to ask the nature of the big picture, but the manner in which it is presented, and whom we ask to speak for it. The creation of collective aesthetic experience, they and Latour argue, is not only equally important to the collation of objective data but also fundamentally changes the way politics of ecological crises must be constructed. In turn, we find that beyond the technocratic ideals of Elon Musk and Silicon Valley which promise technical innovation to resolve issues, these solutions are dependent on the availability of capital. Likewise, the scientific and technical solutions to issues that face humanity as a whole, within a democratic worldview, require a collective decision and urgency to be resolved. Therein lies the need for individual action. In the construction and surfacing of collective urgency and understanding, the question becomes one of narrative and tone. Suddenly the question of ecological crisis is not wholly technological or moral but also requires a voice. In creating that voice mythos and narrative, aesthetic judgement and expression, even the creation of a character itself to embody these values pose an enormous artistic hurdle to the current generation. Latour provides all the impetus necessary for an updated assemblage of the global imaginary repeatedly in 'An Inquiry into Modes of Existence'; "Gaia Approaches."

As will be and has been demonstrated plurally through the environmental instrument, art-practice as a method of attaining intuitive, complex knowledge 

is neither novel rhetoric or a resolved one. Long before the political lens was inseparable from critical theory, the interpretation of natural information and enlightenment, it provided served to some as the measure of a 'true' artist. Such debates are characterized by particularly scathing repartee between oppositional schools of thought. Charles Ginner, a particularly critical Neo-Realist from the Camden Town group in 1914 claimed nature to be the inherent root of all true art. "all the great painters of the world have known that great art can only be created out of continued intercourse with nature." A particularly keen critic of early cubism and abstraction of the period, Ginner found in his time an academism that had stagnated in its attempt to form itself into a new school, arguing that in the attempt to create the formula-illusion which Cubism had been reduced to, many school s had lost sight of the true art of the individual as a channel for new understandings of the nature they represented. He would go so far as to liken this to the fall of grace in the Roman period. For Ginner and the realism he espoused, nature was a strict definition of the surrounding world through which simultaneously the artist unveils the true nature of an emotional and intellectual understanding. Foundations of plural scales of nature and the attempt to synthesize through art and representation like this have been implicit throughout history. Therefore, Latour's struggle is found not in the surfacing of these debates and issues, but in the attempt to expand and reconcile our capacity to represent a non-singular nature through a temporal and expansive field of artpractice. Whereas Harawy expanded on the ethical and practical intuitions of Leopold, Latour's recapitulation of Gaia and the planetary imaginary finds in Lovelock's original Gaia Hypothesis a hidden, intuitive knowledge which came before the language existed to ratify it. The scientific furor raised surrounding the his theories was fuelled by it's use of language, it's tendency to "overanimate" 

what scientific consensus at the time

indicated was static. Just as Leopold

struggled to deliver a set of guidelines

for a concrete ethic of land, Lovelock

struggled to deliver a quantitive prove

that the planet was in fact, animated on a

scale we can barely perceive. 



\section{the agency of the architect}

Sustainability as a socio-ecological issue rather than a techno-managerial issue situates the environmentalist as a part of the ecosystem to be preserved. In the reduction of hierarchy between 'protector' and nature / other, this positions the actions and domestic rituals of the human within architectural space as both the

"the continuation of the culture-nature and man-nature hierarchies by designers when they describe the theoretical and formal attributes of their work perpetuates a separation of human life from other forms of life, vegetal and animal. This separation places people outside the ecosystems of which they are a part and reinforces a land ethic of either control or ownership instead of partnership and inter-relationship."

cause and a potential solution for systems of enormous complexity. This reimagining of processions of space and ritual of space, in turn, makes clear the agency of the architect and designer in the process of recapitulation. Not as an advocate for 'good design,' but as a true combatant in reshaping the daily lives of those whose actions coalesce into the amalgamation of global needs and production. The architect's battlefield, rather than to propose the dissolution of, for example, the great pacific garbage patch, lies in the shaping of the individual routines of the millions of consumers whose ephemera and waste aggregated the patch in the first place. This concept does not merely hold within the realm of art practice but is in fact mirrored in new fields of scientific research into buildings.

As our understanding of thermodynamics and consumption improve, research indicates that sustainable residential design often hinges directly and critically on the lifestyle choices of the inhabitant.

The deployment of traditional approaches to sustainable design, solar daylighting, shading, thermal storage, natural ventilation and other passive design strategies can minimize, or in the case of 

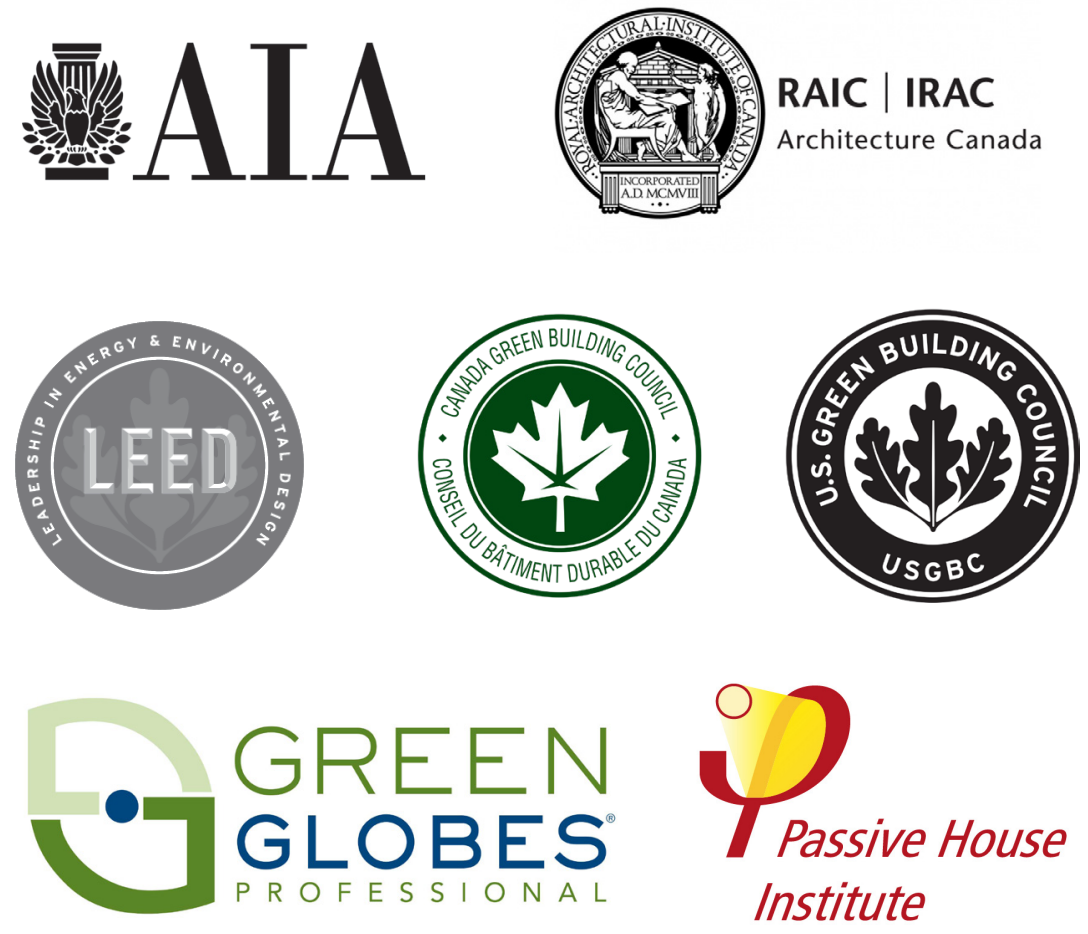


\section{The architect's role in the environment}

Architecture in practice straddles

two, often conflicting drivers for the

project. On one hand, the concept, design drivers and philosophy behind a project gives it it's life and spirit, all architecture aspires towards conceptual clarity and strength. On the other hand, as buildings with inhabitants who have needs, architects must balance their philosophies of design with the practicum of performance in a variety of aspects. However, consistently architects have erred on one of the same principles as Plato did in his 'noble lie', by complicitly and passively suppressing sustainable design where it has been beneficial to our interests, and in doing so removed the true dialogue from the public eye. The danger of this types of suppression of truth is the danger of deception itself, often virtuous in their intentions the educated deceiver obscures facts to promote an individual vision. In the North American environmental context, the resultant climate change denial, as well as governmental suppression of agency scientist's voices ${ }^{2}$ needs to now be actively disarmed to reach a platform of discussion that resolves towards a common truth. Architects have been especially guilty of committing the 'noble lies' of greenwashing, fetishizing and appropriating sustainability, as well as being complicit in corporate strategies of 'green' branding. By critiquing the ethical observances of practice and the results of the mismanagement of this relationship between our profession and sustainability, we can learn better methods for communicating about design thinking, and reflect on the dangers of simplification in a highly complex field.

A distinct, passive duplicity becomes evident under a close reading of various architectural mission statements. Specifically, the broad definitions of terms such as 'sustainability' and 'sustainable design' have been co-opted by the vast majority of practicing architects in describing their capabilities and vision. This can be incorporated into a variety 

of design philosophies without being categorically false, in fact many business owners can attest to the concept of a sustainable method of operation as being integral to the working world. As a result, one might claim that sustainability, being a complex word with a variety of meanings, is inherently widespread and can be ethically used to describe a variety of practices without cause for issue. This is in fact what makes the word so dangerous and harmful to the profession, its ability to stand for a vast array of meanings allows a casual appropriation of the term and all of its positive connotations without having to be held to any type of standard of specificity. Two excerpts have been selected to examine more closely this deception in the mission statements of architects.

These two excerpts, one from the profile of a primarily multi-residential and institutional firm, the other from a boutique residential firm, showcase the variety of definitions and modes of operation which sustainability can encompass, economic, environmental, societal, each with a variety of its own subdivisions. The word has become a passively parasitic marketing strategy, wherein mentioning sustainable within a 'design philosophy' brings with it the positive connotations of environmental sustainability, the perception of a humanitarian and selfless drive to solve the big issues facing our place. The word, despite its variety of applications, can demonstrably be linked to environmental sustainability ${ }^{3}$ at its core, and as a result the willful vagueness of its use can only be viewed as an attempt to manipulate opinions of potential clients and the public into an association between a practice and this branch of design. While the ethics of misrepresentation of capabilities is certainly concerning, the greatest issue with this trend is that it breeds ubiquity, complacence and represses an active discussion about the specific challenges facing holistic sustainable design. The result is an 

environmental discourse which has been robbed of meaning by adoption. It no longer means anything to be described a sustainable designer, unless prefaced with some other assurance of quality, and as a result a highly specialized component of our industry becomes difficult if not impossible to differentiate from the masses, particularly to the uninformed consumer.

The result of all this misinformation, the subtle deceptions and undercutting of a complex make the conversation about the environment and the effect our buildings have on it fragile. When the field of knowledge on sustainable design becomes cluttered, when every architect appears to be sustainable it becomes easier for the appearance of sustainability to hold greater public sway than projects which are proven to be more effective at dealing with the issue holistically. Furthermore, it distances the public opinion from the actual practices of rigorous sustainable practice, resulting in a simplified image of sustainability, equally liable to be used for marketing purposes. This effect, known as greenwashing 4 , permeates through to design, taking the ethical quandary of self-representation and manifesting itself in buildings which lie about their performance through the adoption of systems which look 'green'. For example, I will use the Bosco Verticale project by Boeri Studio, which claims enormous environmental benefits and is world-renowned for its take on urban vegetation in high-rises.

Translating roughly to 'Vertical Forest' The Bosco Verticale project is the first built of Stefano Boeri's thesis on vertical urban ecosystems, an $80 \mathrm{~m}$ and $110 \mathrm{~m}$ tall set of towers clad in balconies covered in trees and vegetation. The argument is simple, and visually effective. These trees will ingest the $\mathrm{CO}_{2}$ in the atmosphere around them, transforming it to oxygen through metabolic processes. The implication is a building which on a local scale reverses carbon emissions, and one can imagine 



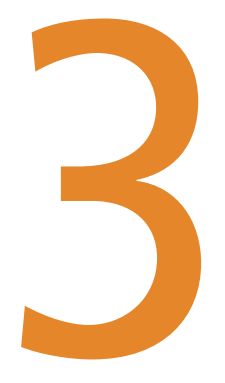

\section{On Becoming an Instrument}

1 A tool or implement, especially one for precision work.

2 A measuring device used to gauge the level, position, speed, etc. of something, especially a motor vehicle or aircraft. 


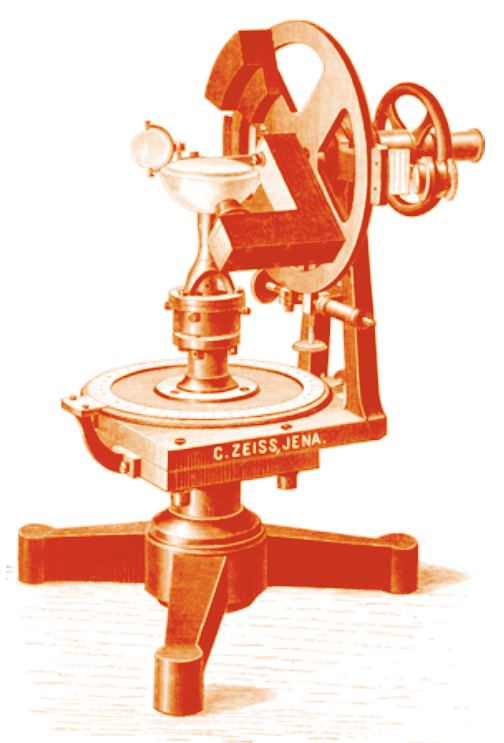

Crystal Refractometer

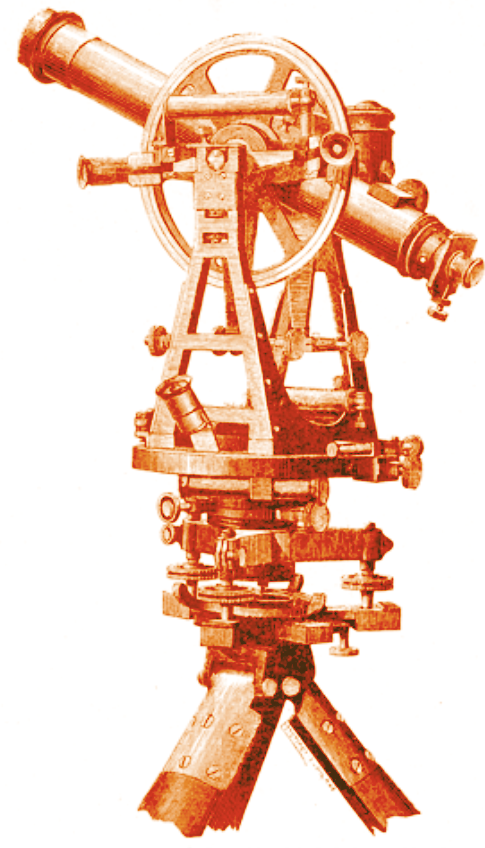

Tacheometre Theolodite

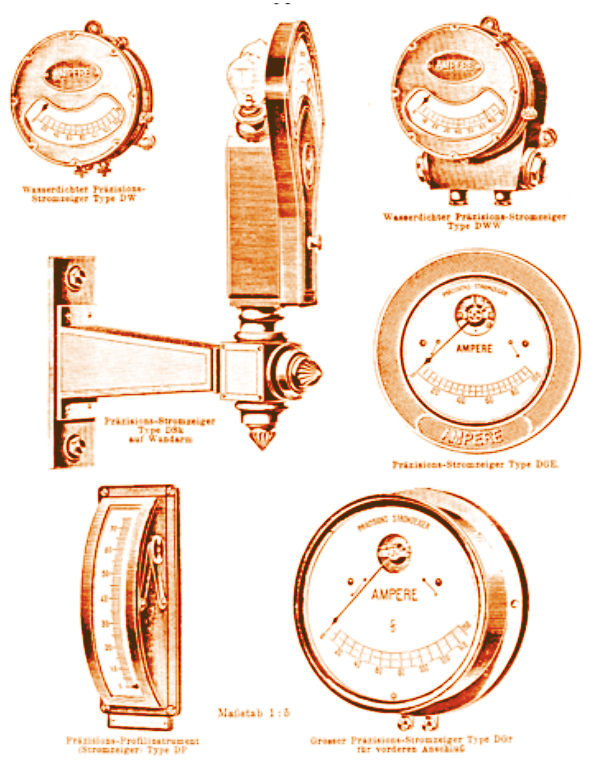

Direct Current Ammeters

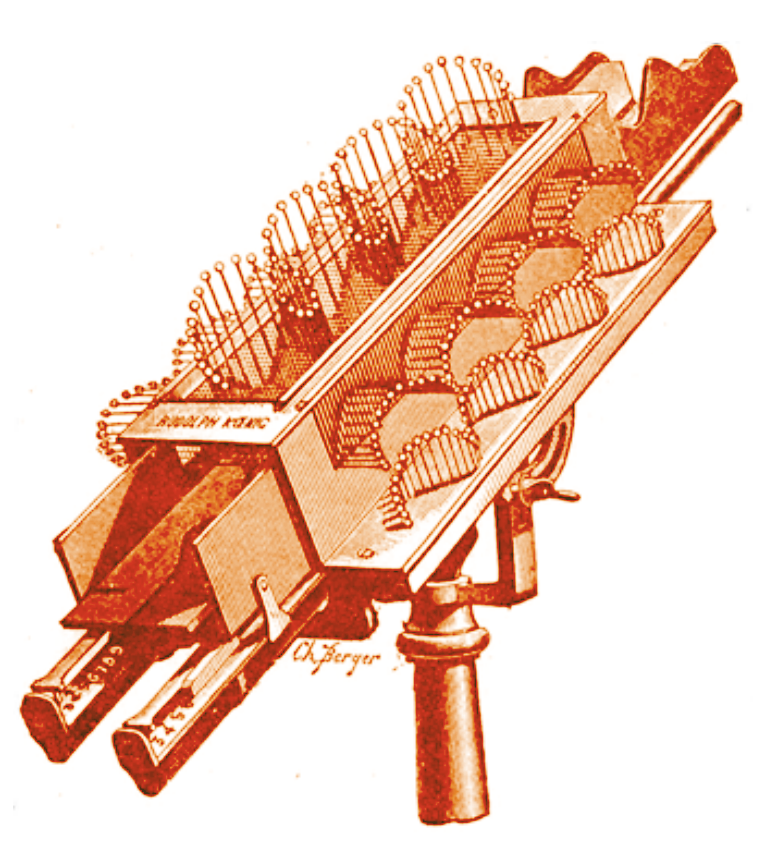

Wheatsone Wave Machine 


\section{instrument knowledge}

In Thing Knowledge: A Philosophy of Scientific Instruments, (2004) David

Baird shines a new light on the storied relationship between human success, knowledge, and our famous use of tools.

A parallel precursor to Heinrich's research on social evolution, Baird's argument hinges around the epistemology of the scientific instrument. He argues that the scientific instrument, the spectrometer, Faraday's first electric motor, and early analytical mechanical models of the universe are not merely tools which foster a singular knowledge within the mind, but that these tools are knowledge. While the tradition in western thought is to view knowledge as a theoretical understanding espoused in the intellect, the traditional model of knowing is to think, to conceive, and to encapsulate verbally, as is the tradition within philosophical thought. Therefore, a conceit is born that diagrams, models, maps and other physical aides are merely that; superfluous to the knowledge itself. This view of nonintellectual knowledge as a crutch or pragmatic aide begets the dumbness of the scientific term, instrument. As an environmental instrument, this proposal for a revised architecture in nature aims to reclaim the scientific understanding of the instrument within the realm of art, place-making, and the dissemination of knowledge. Rather than acting as an information station, or a glorified literature absorption space, the architectural instrument privileges knowledge of the tactile, intuited kind. In combining of the epistemology of the instrument and the art agency politics of the land artists, we can find the tools to find knowledge in a deeply pluralistic worldview, knowledge which is rendered accessible to all through the open data format of experience and phenomena. Just as Smithson, Heizer, and Art Forum's Philip Leider had begun to observe, the reduction of knowledge, artistic or otherwise, to a purely linguistic or theoretical mode enacts class divides and removes the conversations taking place from the realm of the open-sourced public. 


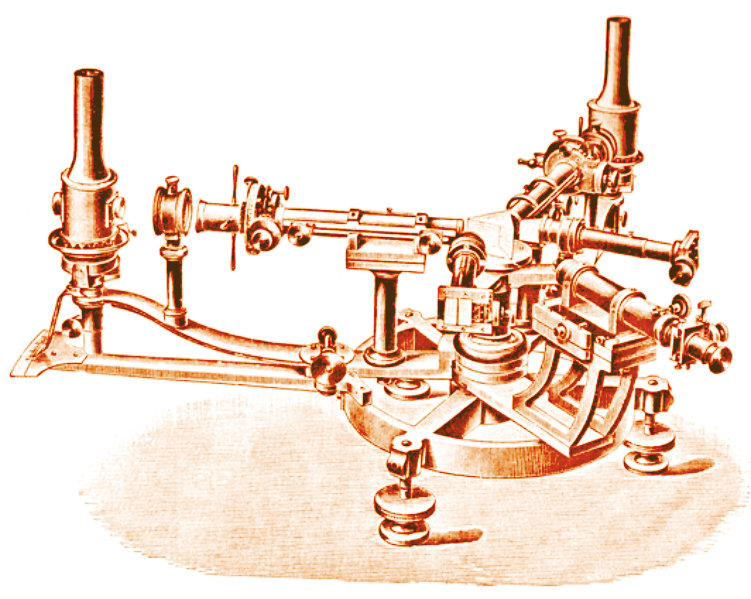

Colour Mixing Apparatus

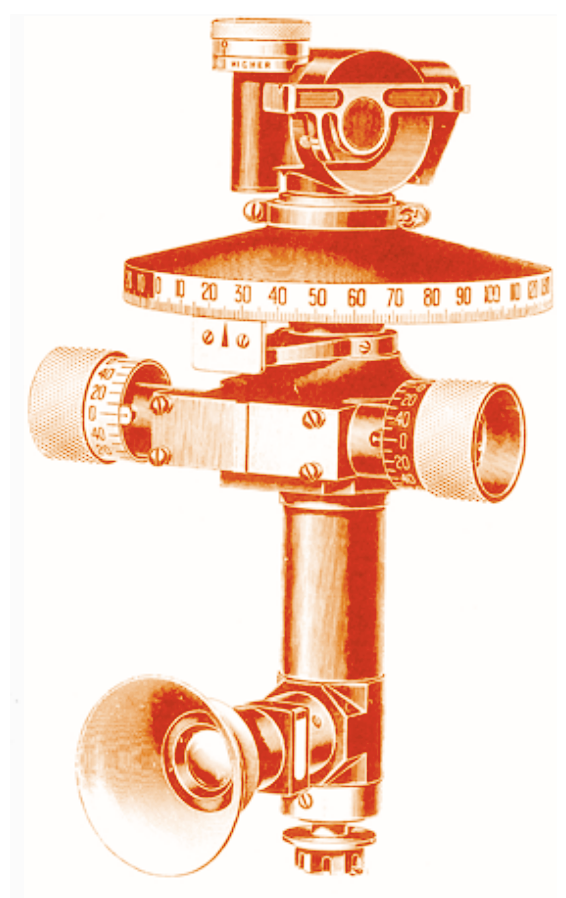

WW1 Dial Sight

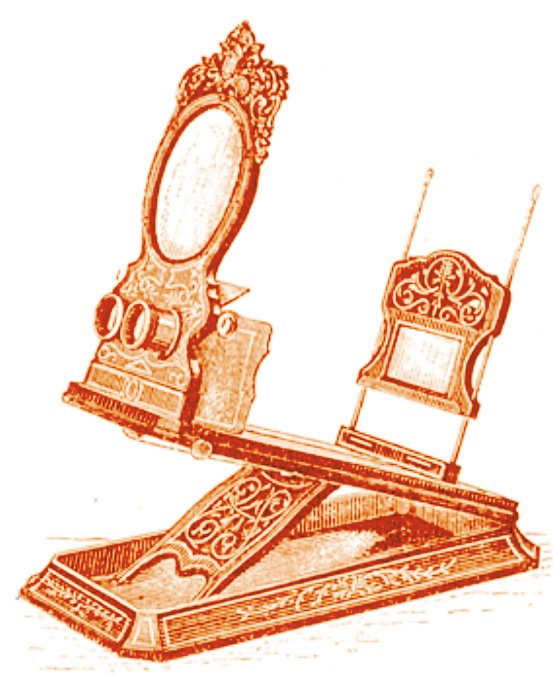

Aperiodic Mirror Galvanometer

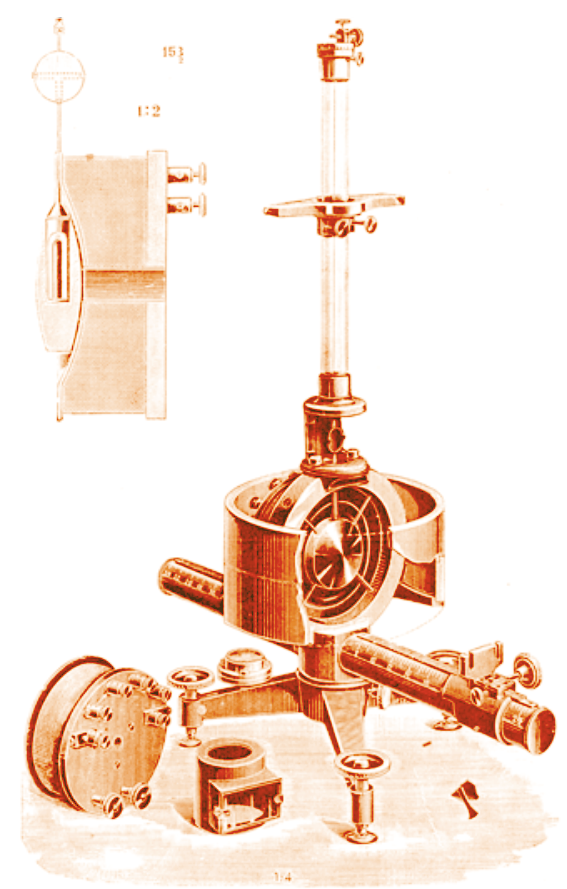

Graphoscope 
An architectural language of instrumentation leverages the existing tools and methods which have existed for centuries. Instruments measure, encode, and render data and conditions of the physical world into digestible, objective datum. In translating these parameters, we find that the elements of the instrument can all be found within the realm of architecture. This proposal is not one of radical change and shift or one which turns an industry on its head, proposing a top-down restructuring of the system. Instead, this proposal is one of realignment, of calibration. Concerning a building, the measuring capacity is found in the siting and creation of the building. All buildings in this way, are measuring time, data, their environment, but most buildings are no calibrated to render this data, with some, in fact, being specifically maintained to erase the datum points of time and hardship. Physically, climate and weather can be codified through dirt, stain, shifts in the foundation, changes in temperature, soil and water levels. This codification is then rendered through the use, the smooth finish of a worn stone step, the draft the centre point of a pane of glass, the line of patination and weather which distinguishes the extents of pulverization.

Most importantly of all of the architectural narratives of the instrument, however, is the site itself. Within the jurisdiction of the term site, the architect will find a condensing of scales and narratives of data which determine the responses of the building. At the size of climate can be ascertained prevailing weather patterns, precipitative intensity, and the beginning of the societal value. At the territory, we find the richness of vernacular response to animal and plant species, morphological context and means of access. On the visible scale are the formal peculiarities of the site, the organization of major fauna and topological features as well as the relationship to the public. Finally, the scales of the detail and microscopic in turn contain the compositions of 


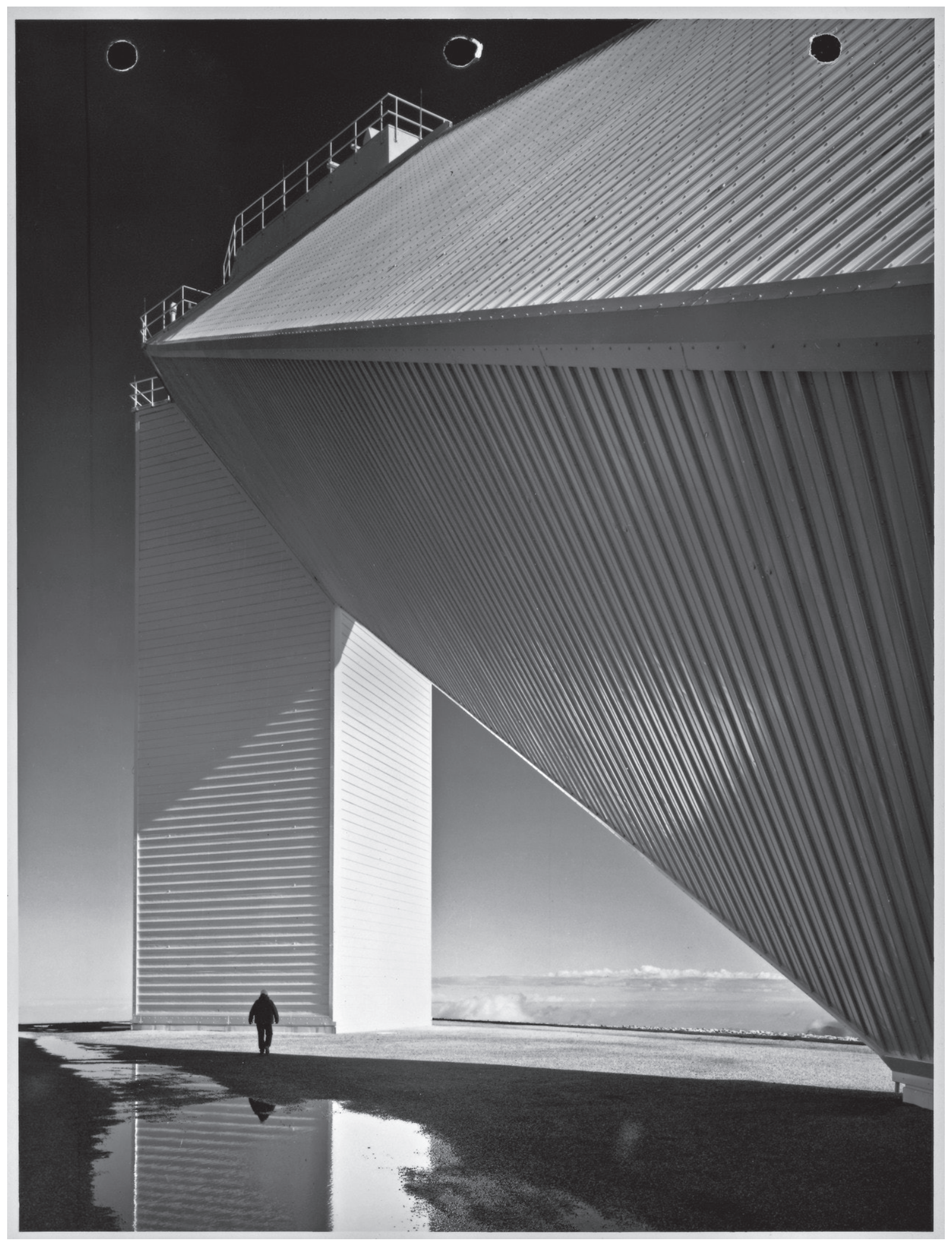

Figure 14: McMath-Pierce Solar Telescope at the Kitt Peak National Observatory, designed by Skidmore Owings \& Merrill 
various vegetation, air, and water which are formal to the rates and production of patinas, rust, and large elements of architectural character which develop over time. The conception of the architectural instrument, especially with the intention to eliminate or reduce bias in 'readings' requires the architect to act in the modified role of the calibrator. The role of negotiation between the desires and needs of many actor-agents must be modified in this process to remove the calibrator from the point of explicit authorship. This distance is caused by a key difference between the design authorship of an instrument from that of a traditional building. The important authorship of the instrument is in its ability to reveal the hidden, and therefore the type of knowledge contained. Similar to a camera in functionality, the primary design authorship of a given camera make rarely hinges on the formal character of the body, although this quality is not without considering for its value. The primary value is the balance between the skills and understanding of the camera maker, as well as the interpretations which will then be made through these parameters by the camera operator. In this way, the instrument as architecture became more so a lens cali-brated for its environment than the formation of a container for a specific program. 


\section{Architectural Projects with Analog Interaction}

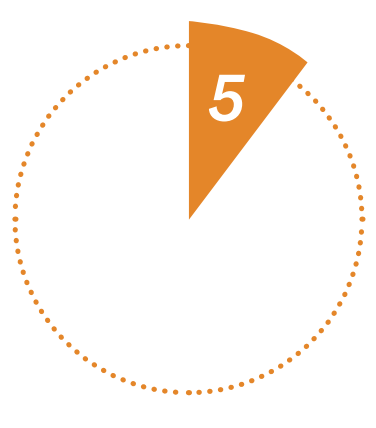

Discrete System

Non-Iteractive

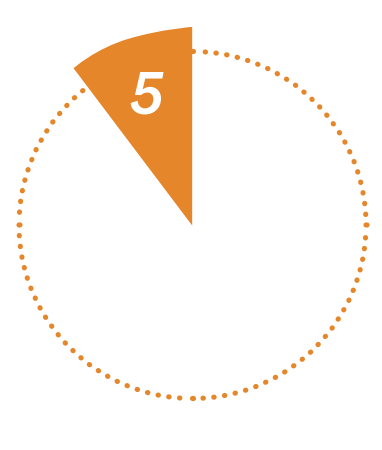

Open System

Non-Interactive

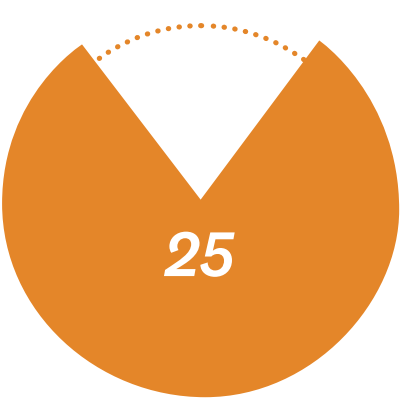

Discrete System Interactive

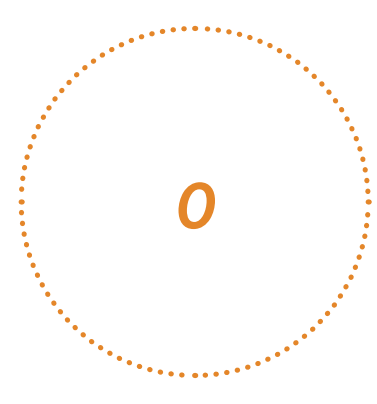

Open System Interactive 


\section{case studies in Interaction}

A selection of key precedents in the

development of a design language and

methodology for interaction with nature.

The pedagogy and aesthetic responses of these projects are of incidental interest, their inclusion here being primarily focused on the philosophical differences

between varying implementations of interaction with the environment in architecture and art. 

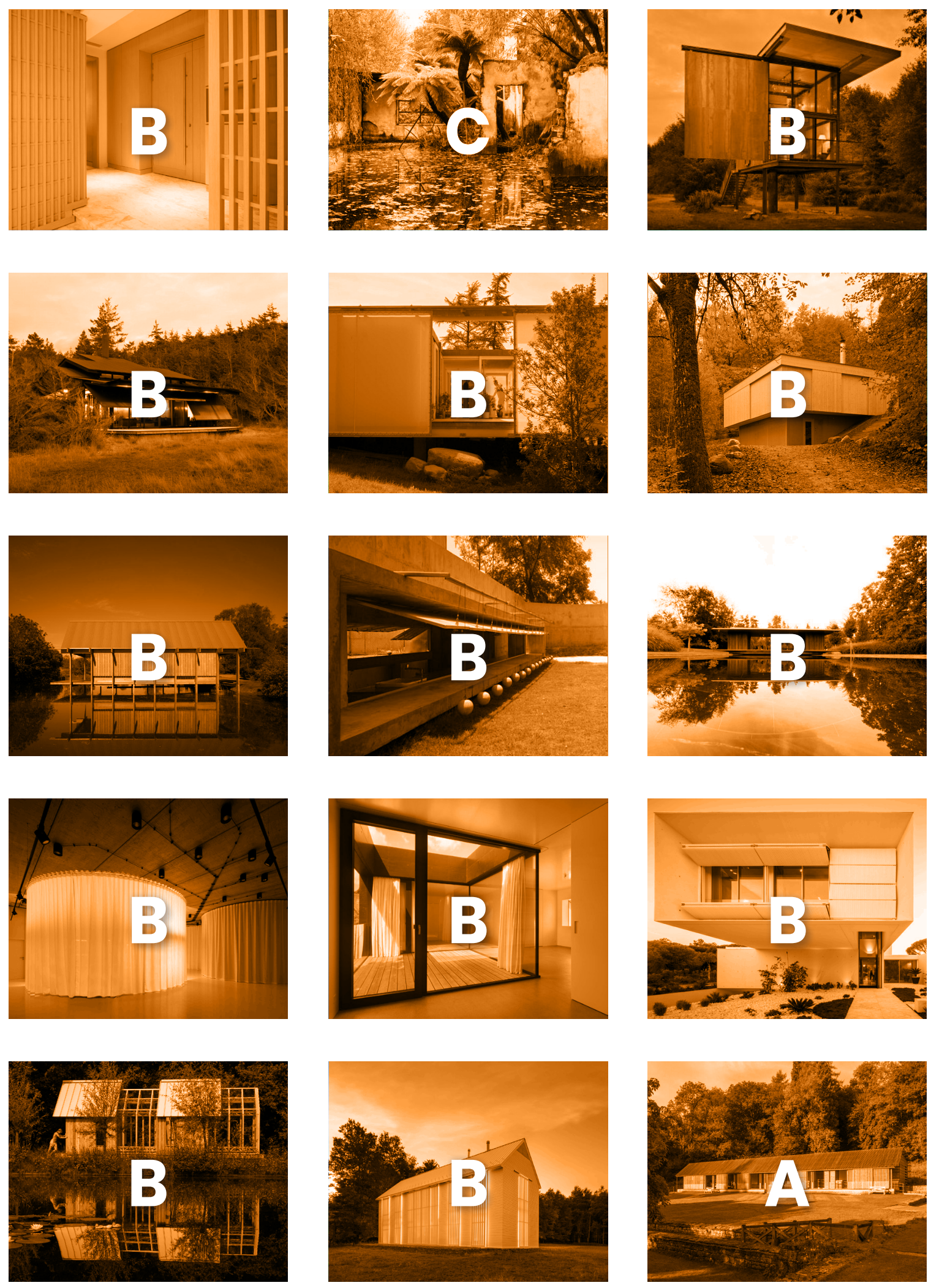

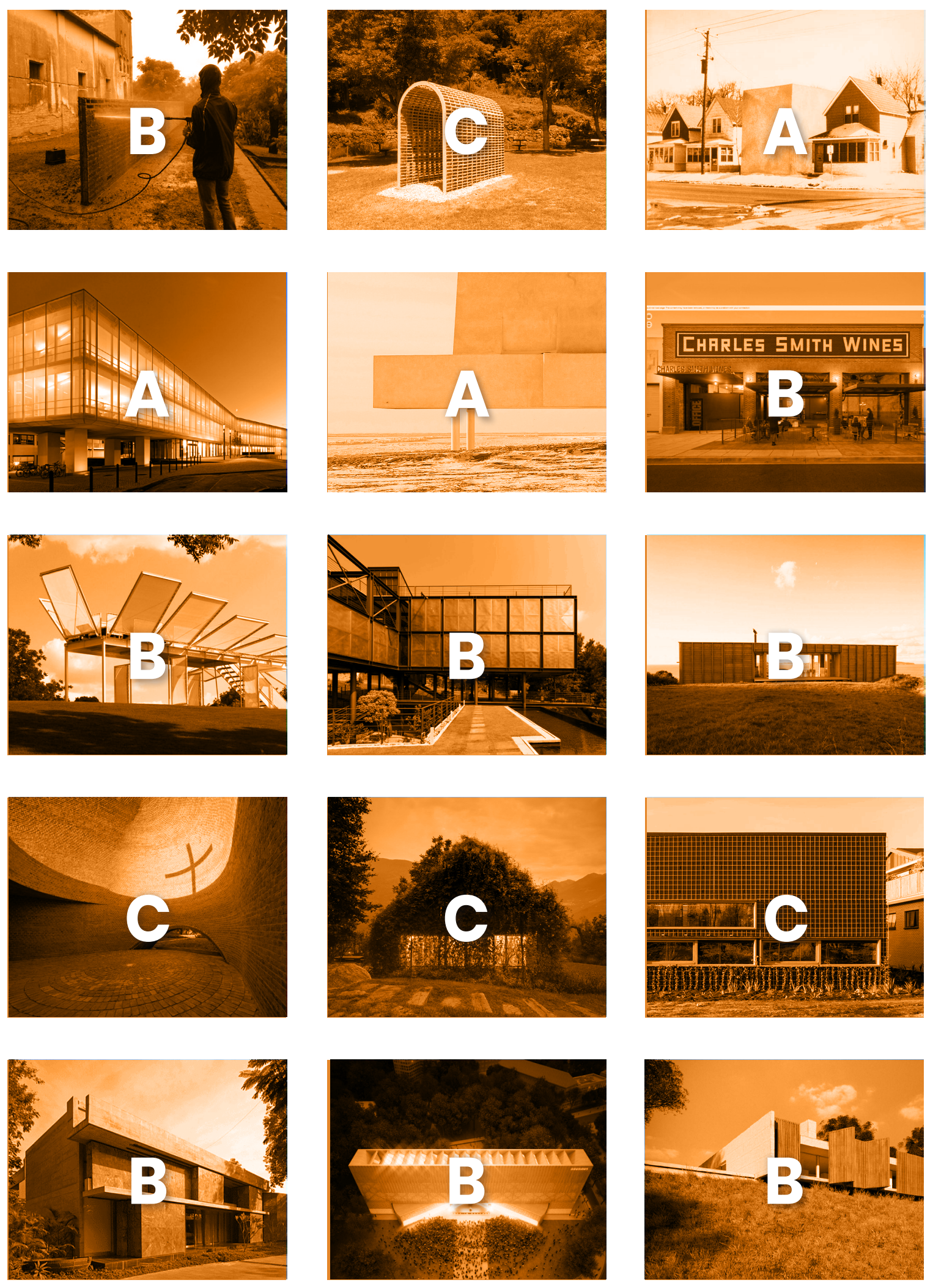


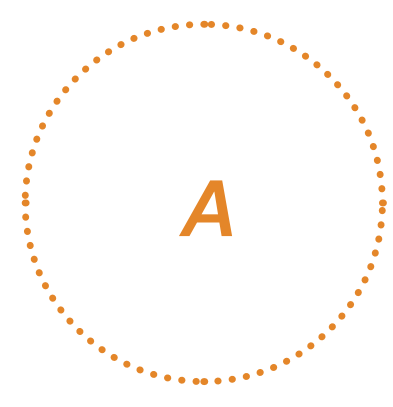

Discrete System

Non-Iteractive

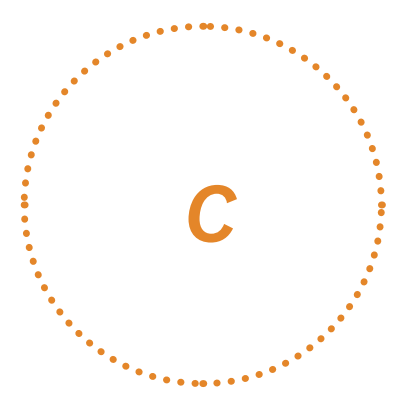

Open System

Non-Iteractive

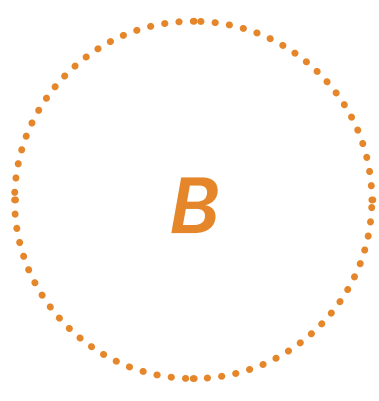

Discrete System

Interactive

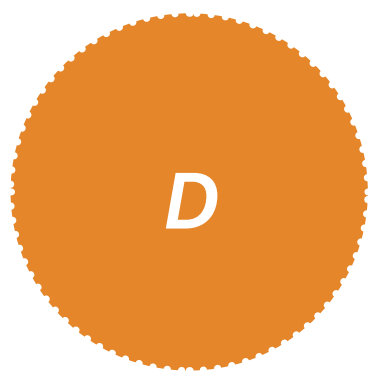

Open System

Interactive 


\section{The Missing Type}

In breaking down analog, intuitive

systems for interaction in architecture

which interfaces with nature, the

implementation of interaction can be reduced to two categories. First, the possible variations within the designed

system can be described as either discrete, having a limitted number of possible configurations, or non-discrete, have a gradiated or open ended number of configurations. This categorization illustrates whether a system is capable of registering a pre-determined number of factors in an environment, or whether it will be able to take on patterns and reactions to unnacounted for factors and complexity. Secondly, the designs can be categorized as interactive or non-interactive. Is the user an active participant in the changes being registered, or simply an observer of change with no change for tactile interface? This creates the set of 4 options outlined opposite. The vast majority of art projects considered researched, and the totality of architectural projects have belonged to category A, B, and C. The missing type, architectural projects whose expression derives from non-discrete, interactive systems to create a dialogue with local climates and nature, is the foundation for the design "instrument" portion of this thesis. 



\section{Engaging in Architectural Statigraphy}

One of the primary benefits of

architecture as an interaction medium

with nature is the intrinsic tie between the

inhabitation of space, the mediation of

the elements and the celebration of their

processes, rather than simply the control

of them. Louis Kahn, Aldo Van Eyk, 

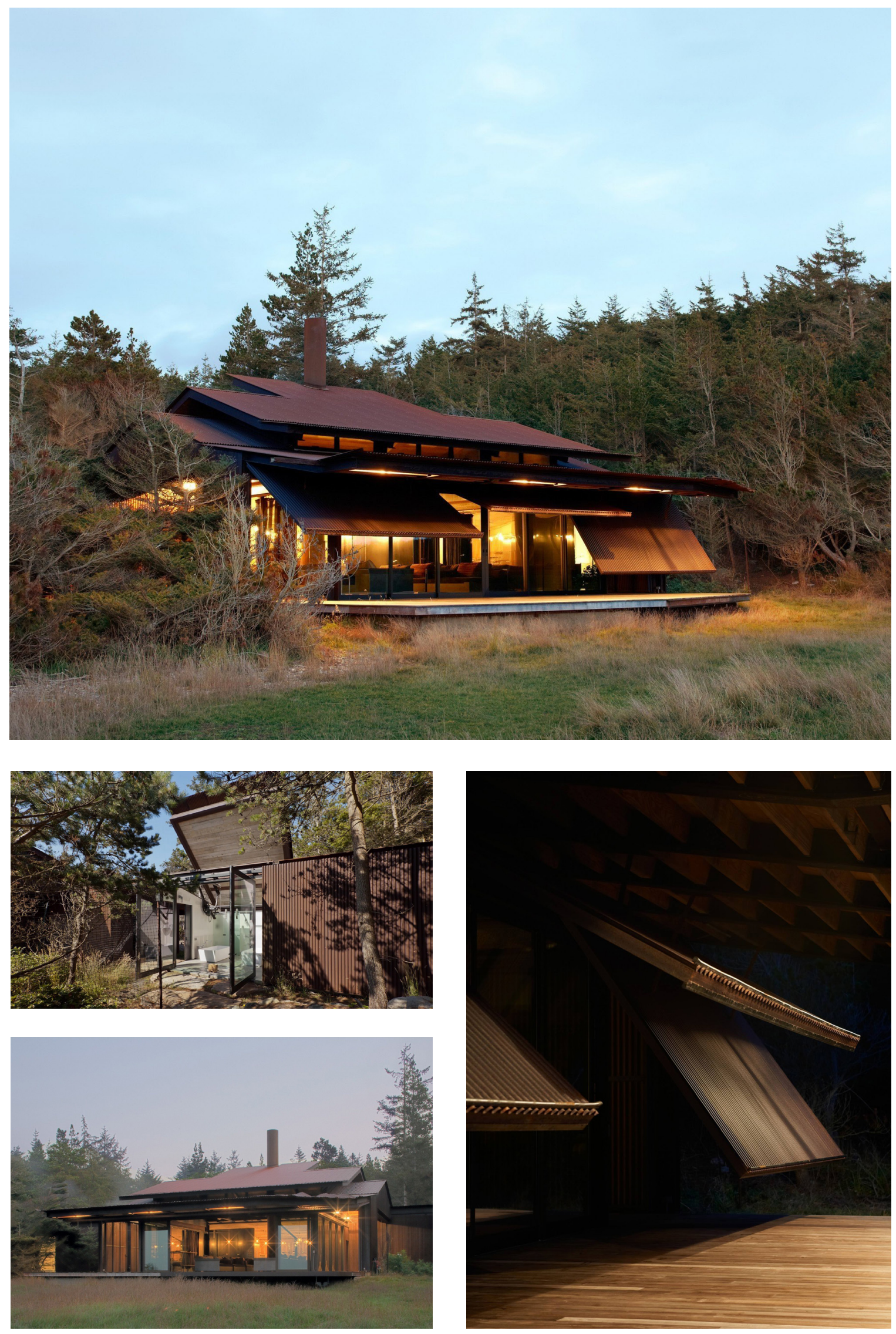


\section{ShadowBoxx - Olson Kundig}

The works of Olson Kundig are precedentsetting in a unique approach to their continued use in mechanism as a part of architecture experience. The user in Olson Kundig's projects operates the colossal windows and shutters with cranks and levers. Engineered with an industrial

understanding of counterweights, pulleys and basic physics, these tactile interfaces reduce the acts lifting, sliding, and rotation of monolithic building elements to the physical strength of even a child. Typically, these devices are linked to site lines, views, and the interface between exterior and interior space, and creates a controlled, tactile interface between the user and the landscape, urban or natural, which the building inhabits. Strictly analog mechanical systems link this relationship directly to motor action in the human body, fostering and encouraging a psychological link between the action of the hand and the grandeur of the landscape which is revealed in the process. 

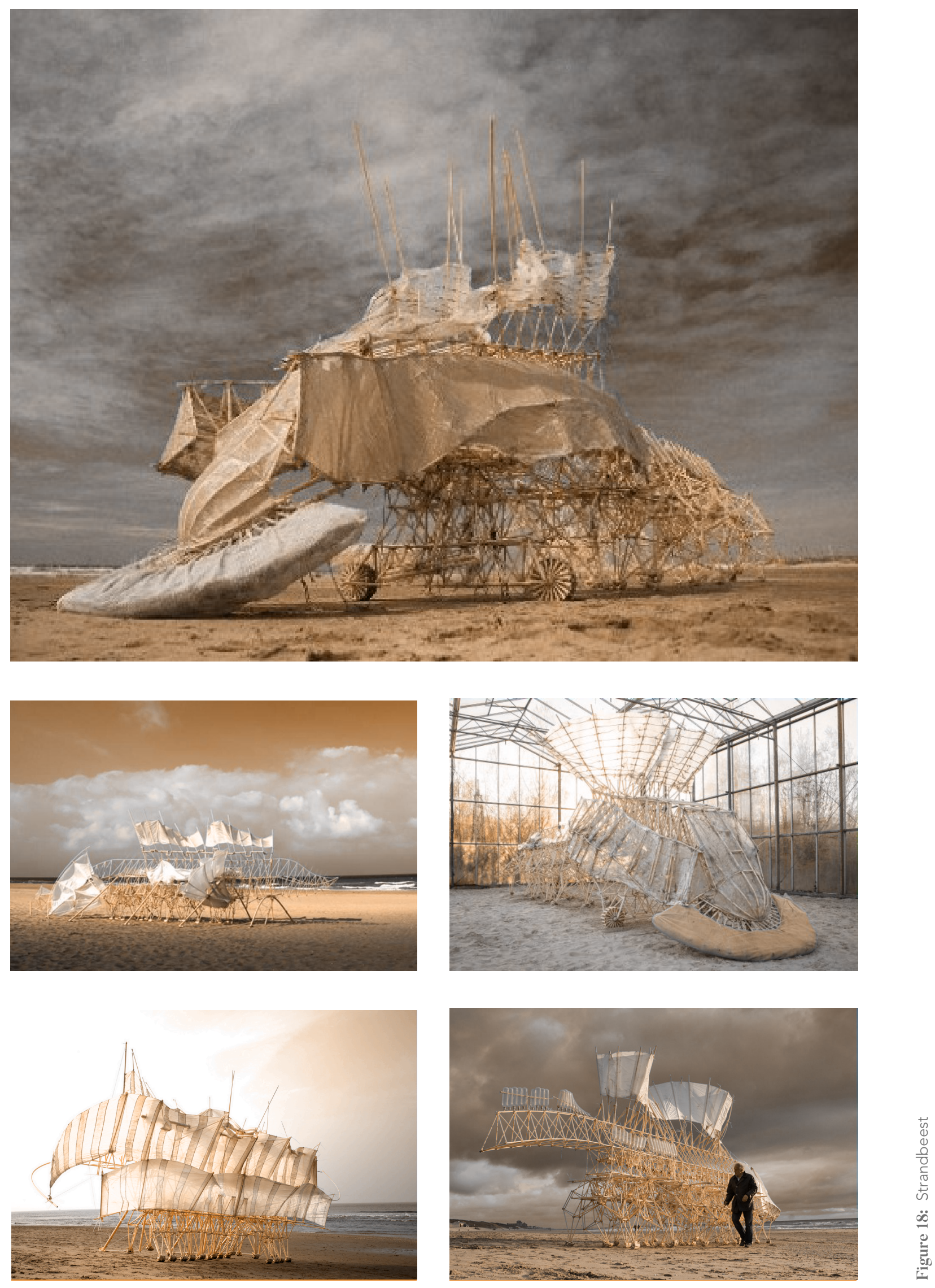


\section{Strandbeest - Theo Jansen}

Theo Jansen's Strandbeest project is a vital reference in dealing with life and evolutionary processes. Unlike architectural precedents with an inherent program, an agenda to which life's attributes must be copasetic, the Strandbeests are an exploration in creating life for the purpose of survival. Jansen's techniques are illuminating both technically and creatively. The birth of his project was inherently darwinistic in process, not out of attempts to emulate natural selection but due to the efficiencies provided by natural selection. Taking for example the mechanical movement responsible the Strandbeest's ability to walk, despite material and compositional simplicity, the number of factors makes the design problem impossible to grasp in its entirety. Each of the seven elements of the walking motion could take on dozens of potential lengths and connections, resulting in hundreds of thousands of possible permutations which even a computer could not process. So, by testing a select number of criteria, selecting those that were most successful and further testing variables within that selection Jansen was able to systematically (with the accelerant of technological physics simulation) select towards the best design at a high efficiency. The result is the slow (still many years have gone into his most recent experiments) development of living Strandbeests, far too complex to be singularly created. 

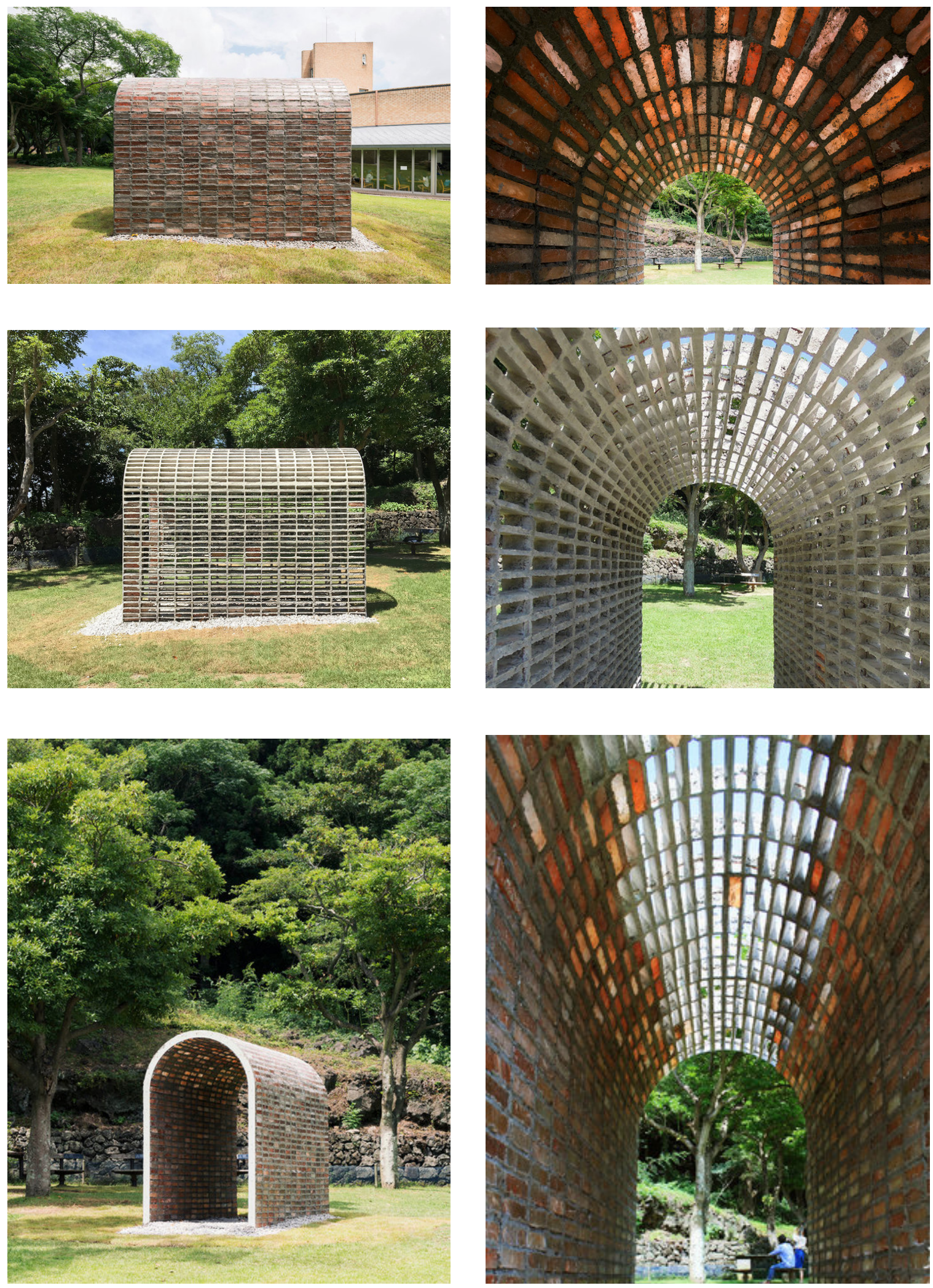

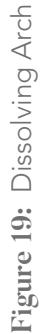




\section{Dissolving Arch STPMJ}

The dissolving arch installation links

precipitation and weathering directly to a

formal architectural response. Over three

months the entropy shapes the expression

of the arch, through the particularities

of site, climate, precipitation, and

architectural form. Over the course of

these months the volume, acidity and

frequency of precipitation are laid bare for

the visitor. Rather than through didactic

panels, media or human interface and

tours, a learning experience is provided

solely in the language of architecture.

The dappling of light through variably

dissolved salt, the breeze created by open

formworks, these experiential qualities

allow the user to experience trends

and factors of the site which conscious

experience and reflection might take

months to develop. 



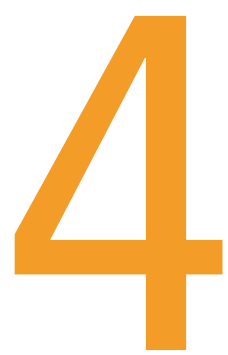

Calibration 


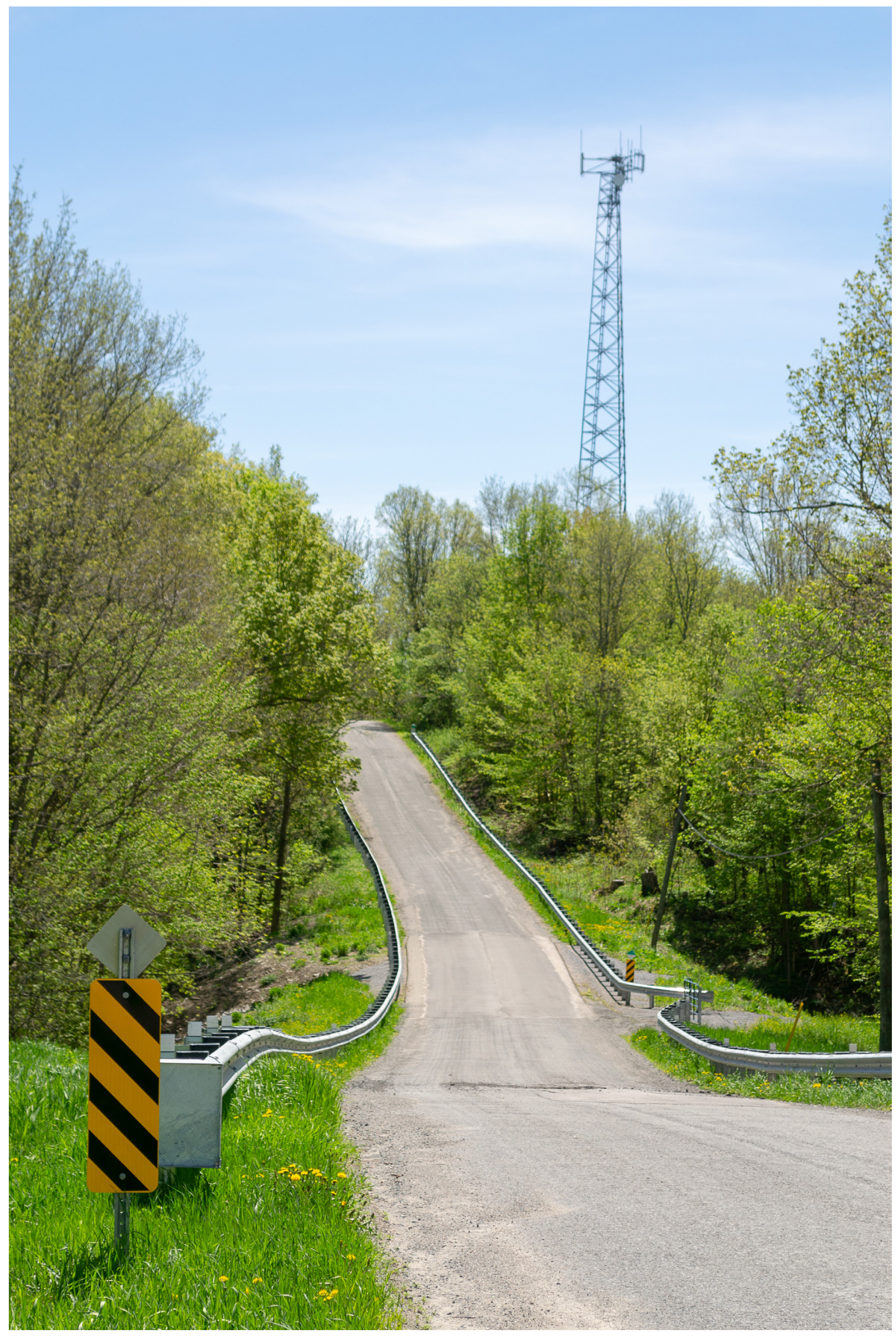




\section{The Spirit of Howe Island}

The island community of Howe Island is here presented through images of local vernacular, and the variety of ecosystems and processes encountered on the island. 


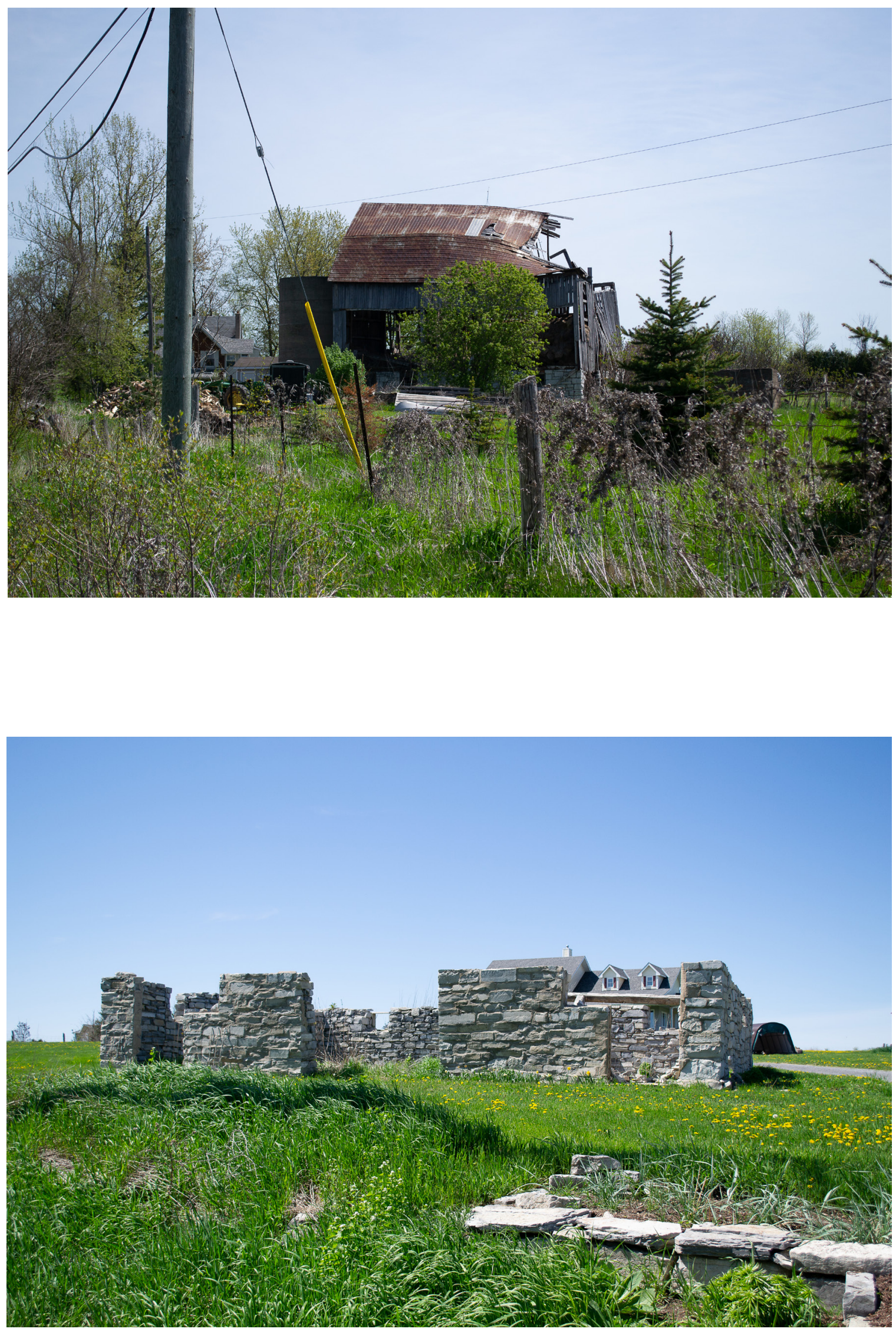

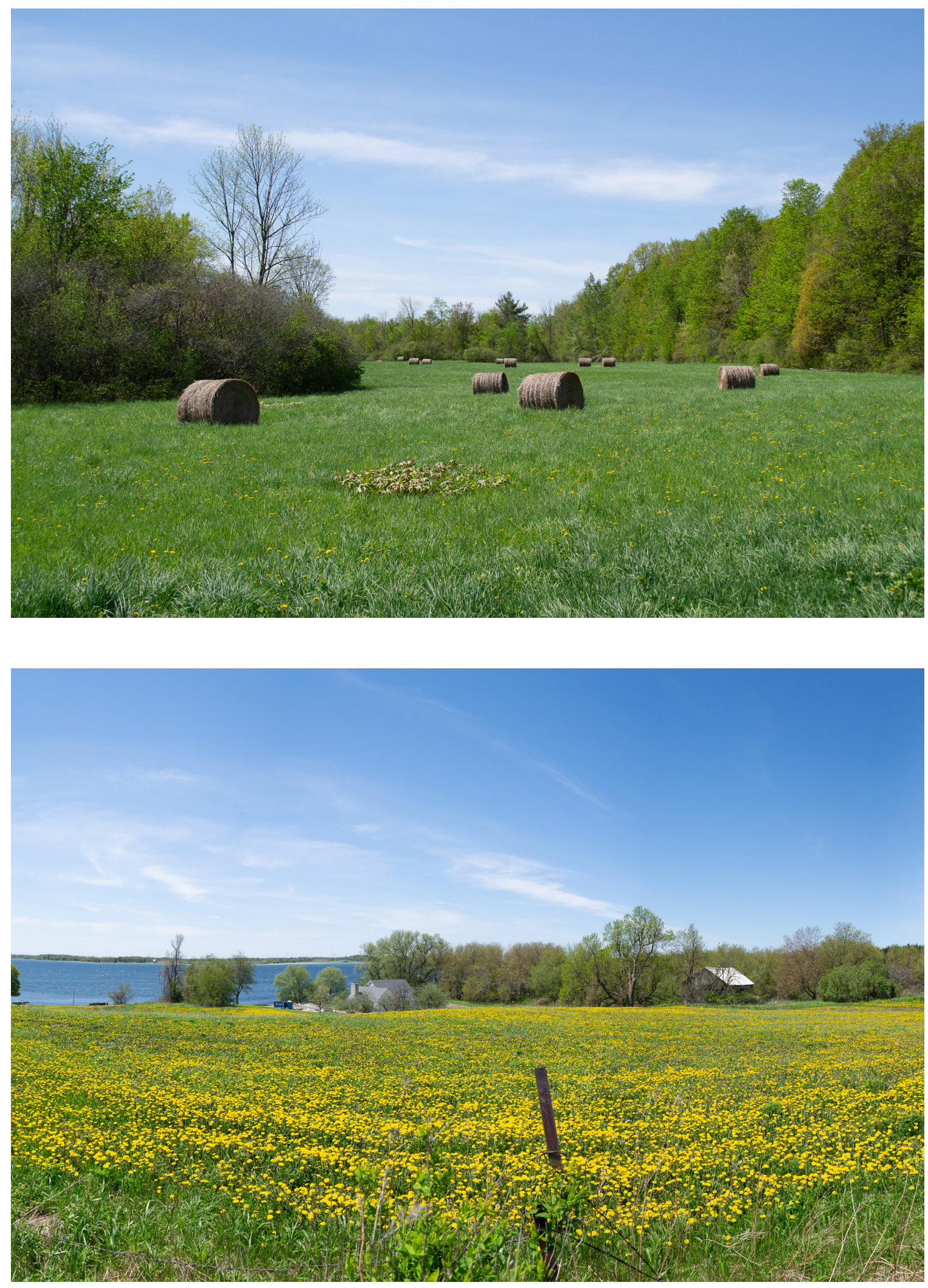


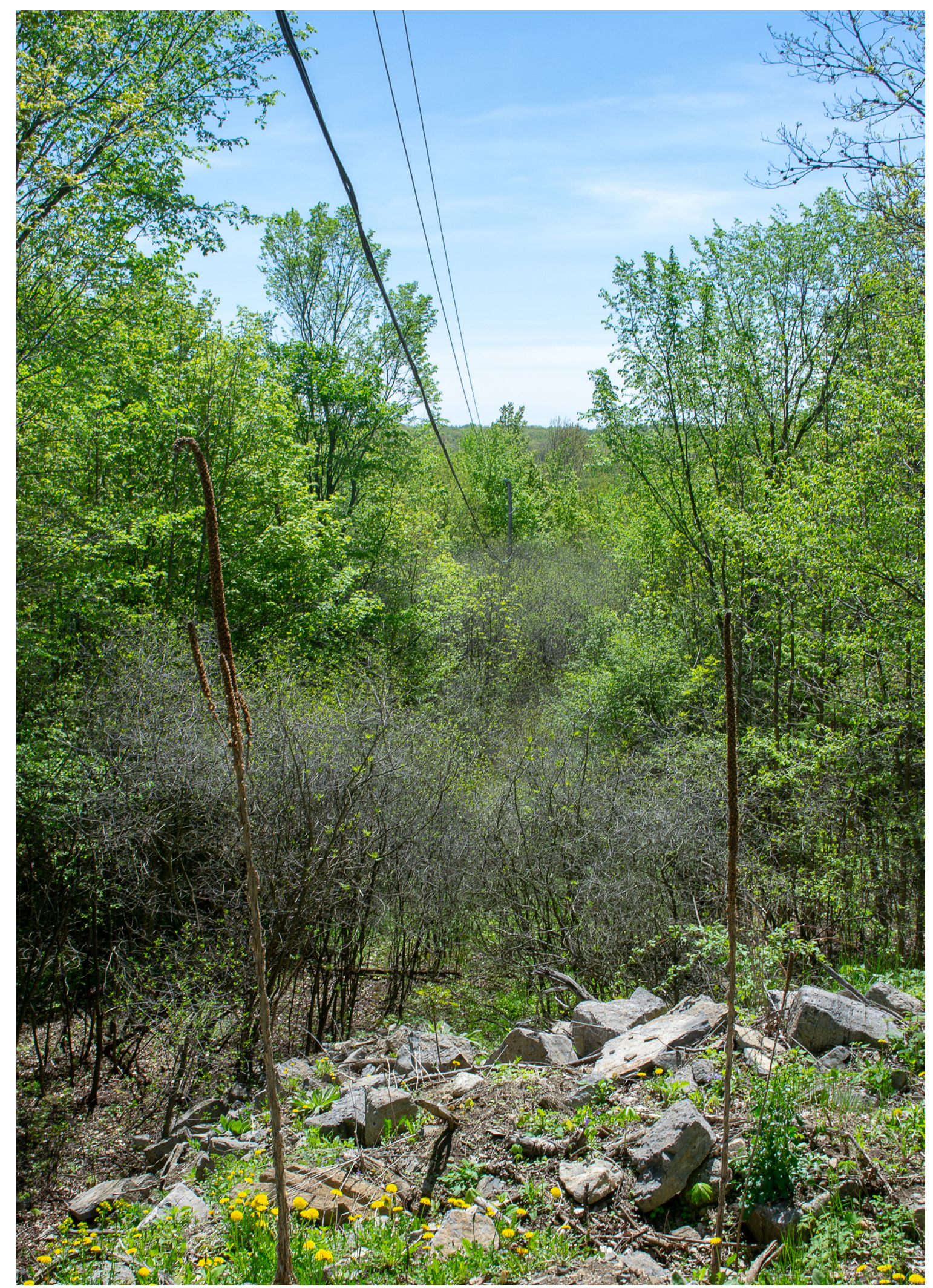

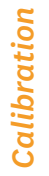




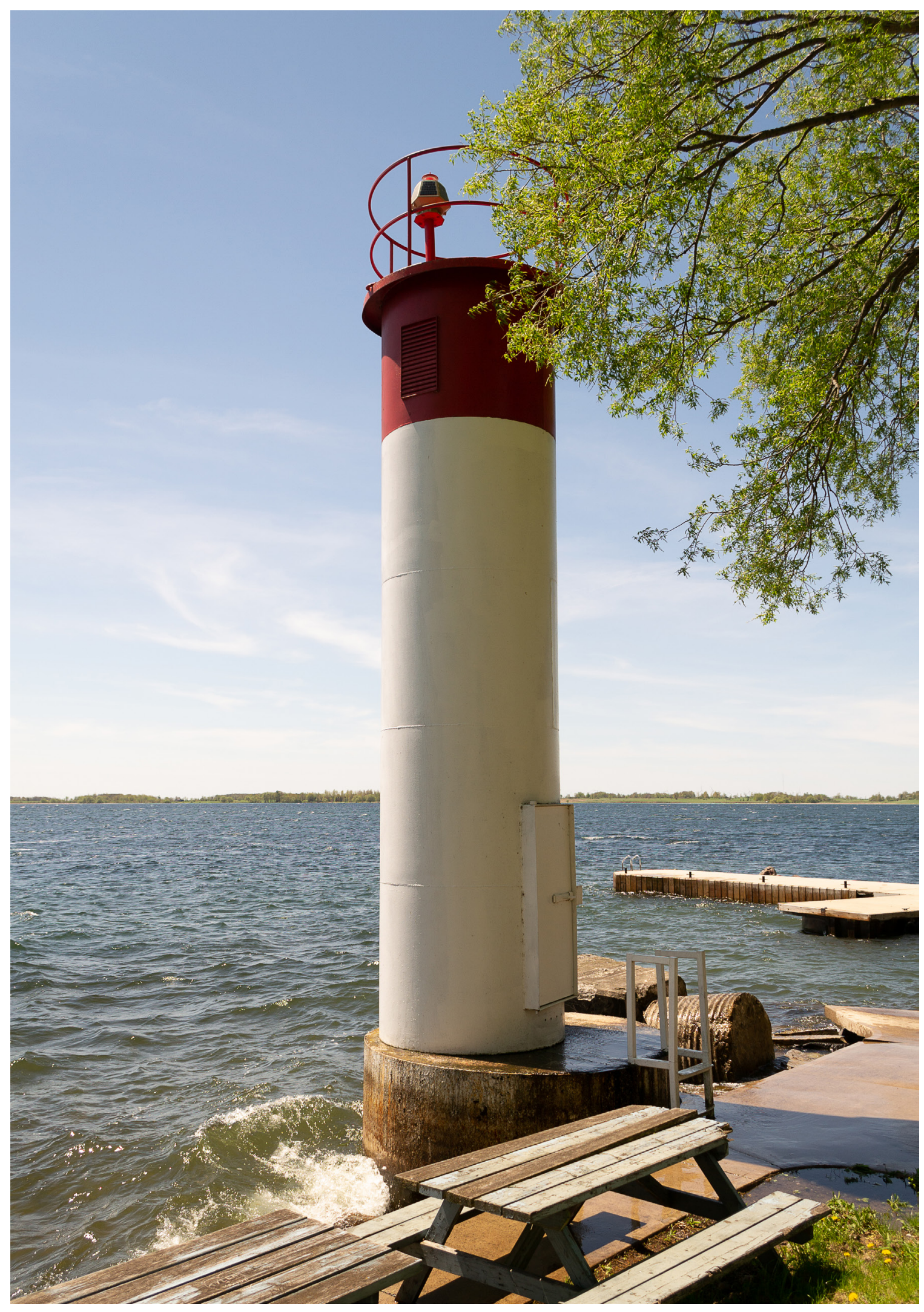




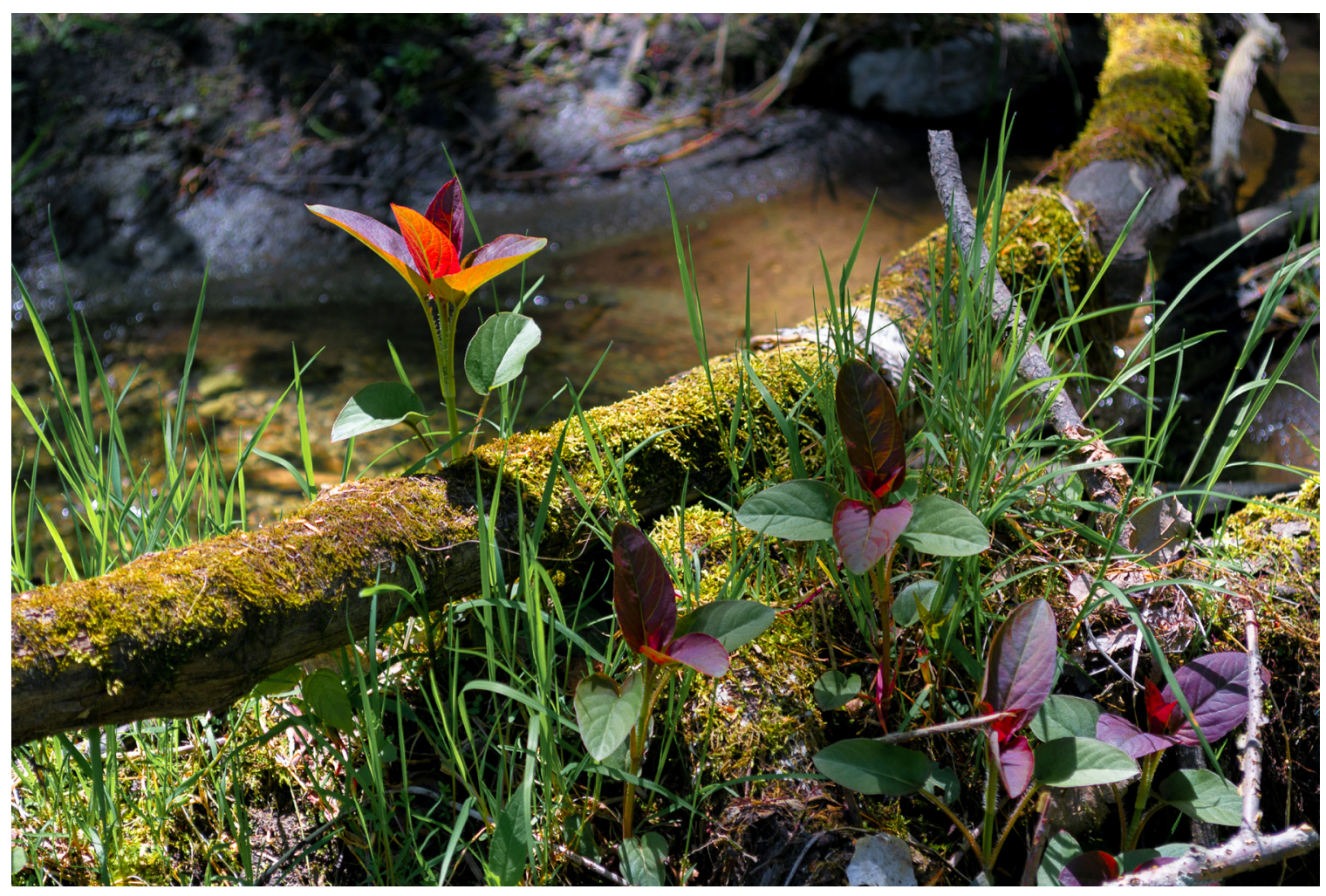

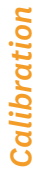

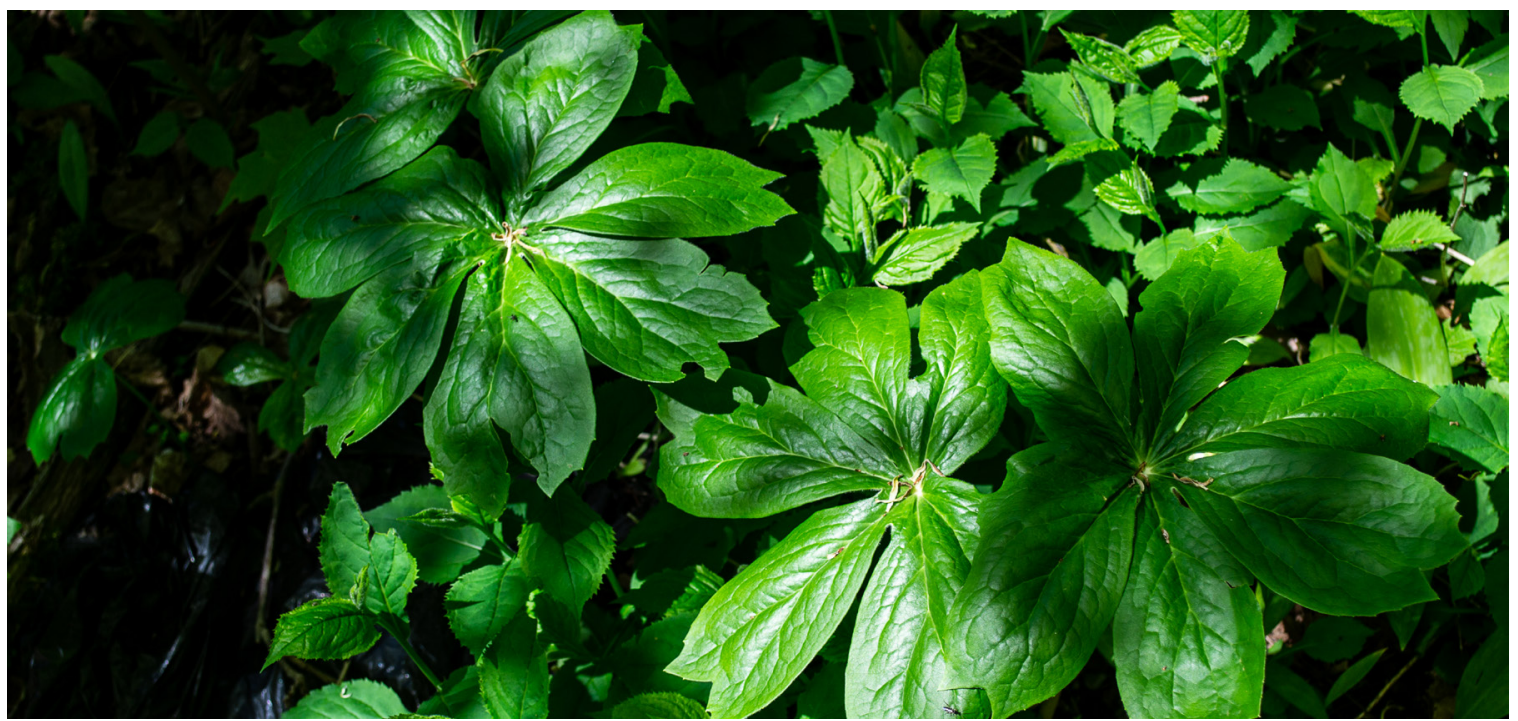




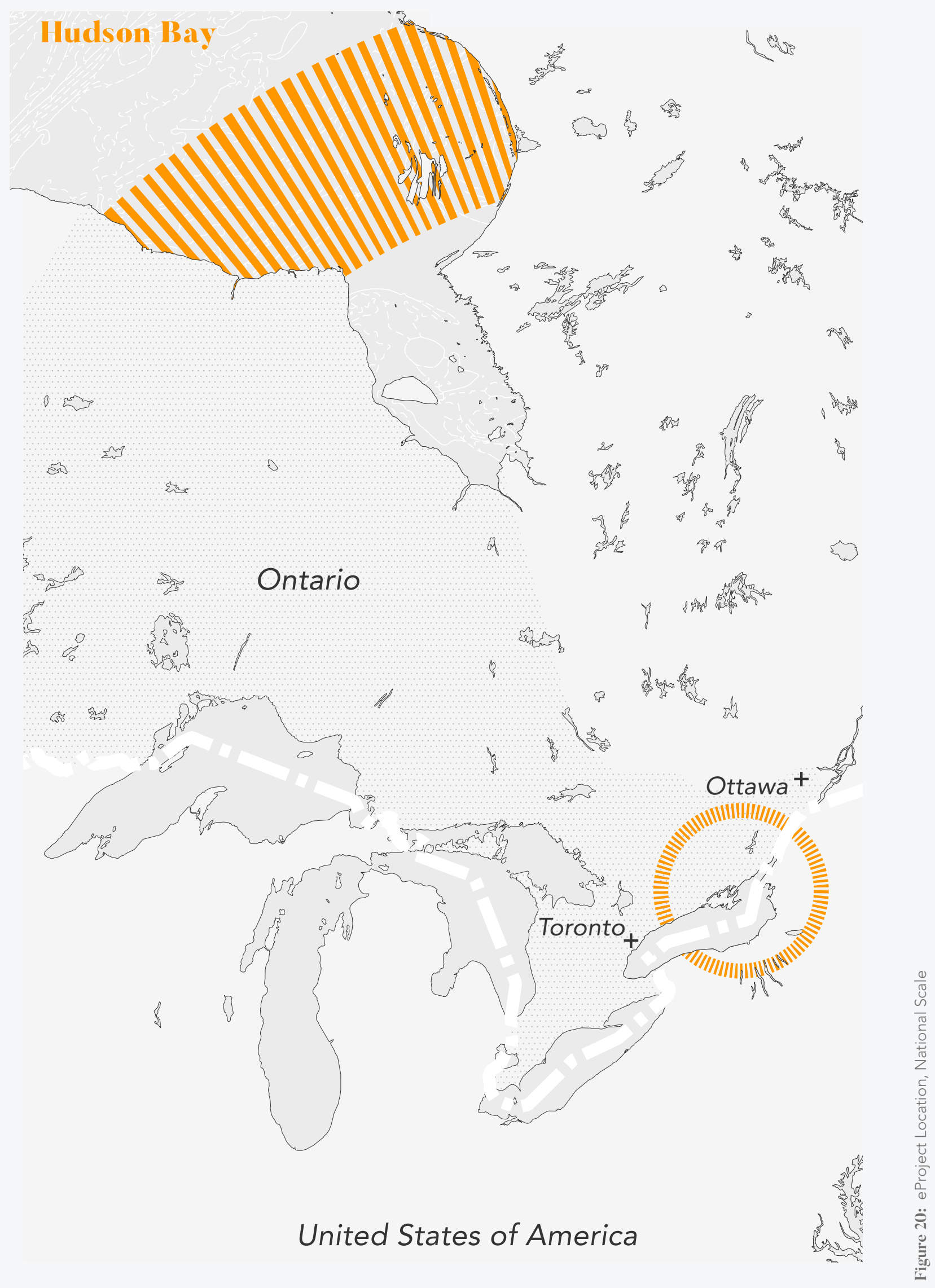




\section{fresh water globally}

Roman engineers and builders spent decades working to provide it consistently to the populous. These aqueducts, architectural marvels in their own right, travelled hundreds of kilometres to provide citizens with drinking water, and their distribution and management systems were deeply embedded with the traditional social hierarchies and politics of urban planning. The kingdom of Egypt's agricultural revolutions and therefore many religious beliefs centred around the Nile's distribution of it. Mesopotamian creation myths pointed to the waters of the Tigris and Euphrates rivers as the temperamental heads of their pantheon which governed life itself. To this end, their failures in irrigation technology which would eventually lead to the salting and desertification of the fertile crescent led them to attribute mineral salts to the god of death himself. Contemporaneously, mismanagement of freshwater resource extraction through technological opportunities have caused political strife, conflict, and the crisis in Yemen, an area which, during Roman times, was known as "Arabia Felix" (fortunate Arabia in Latin) (Romano, A. 2004).. The importance of freshwater both as a political and ecological resource is immense. Of the global supply of fresh $\neg$ water, Canada contains or shares with the United States $20 \%$ or $7 \%$ of the world's renewable freshwater sources. (Citation needed, Water in Canada Publication) Within a climatic agenda for freshwater management and freshwater habitats, Canadian policy will be foundational to global conservation policy as a result.

Within the Canadian hydrological waterscape can also be identified a deep mythos rooted in traditional practices of coexistence with Gaia. Within the great lakes territories, the Anishinaabe and regional indigenous North American belief systems espouse a deep reverence and importance on freshwater. Beyond the typical cultural imagination and narratives of water as life-giver, dialogues of purification and ceremonial rebirth provide a unique character to water in the belief systems of the land. 

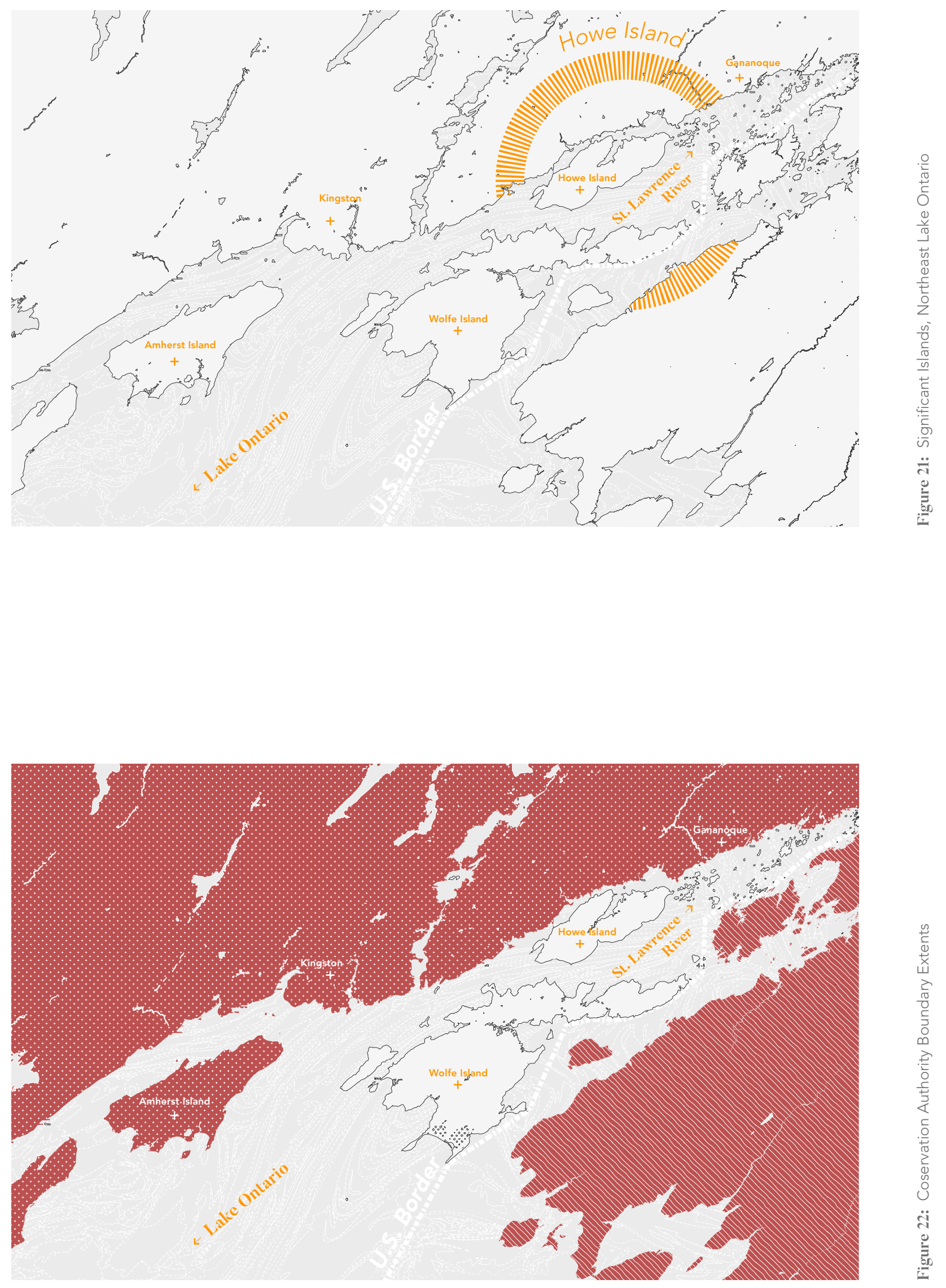


\section{the great lakes lake ontario}

The Great Lakes Basin straddles the Quebec and Ontario borders, as well as the borders of 8 States (Illinois, Indiana, Michigan, Minnesota, New York, Ohio, Pennsylvania and Wisconsin) whose watersheds and water management behavior affects the great lakes.

The protection and conservation strategies for these 10 political regions is outlined in the 1985 Great Lakes Charter, the 2001 Charter Annex and the 2005 Sustainable Water Resource agreements(Gouvernement du Québec, n.d.). These international good faith agreements are made binding through the institution of domestic laws at the provincial and municipal level. Water level, ecological health, wildlife population and myriad factors are affected both by these agreements and natural factors such as watershed rainfall, weather patterns and development which threaten the rare and diverse environments contained.

Lake Ontario's islands are especially prone to the Canadian pressures. Its watershed contains 8 of Canada's 20 largest cities and is exposed to some degree of the adverse effects experienced upstream as well. The political boundaries drawn by conservation experts and politicians protect some resources and habitats while exposing others. Ontario's Conservation Authorities are the designated agencies responsible for the use and governance of natural resources. Southern Ontario contains the lion's share of these authorities, with close to full coverage. As political conservation entities, their jurisdictions determine their ability to govern and oversee due process. The borders local to Howe Island, those of the Cataraqui Region Conservation Authority, do not include Howe Island, Wolfe Island, or the remainder of the 1,000 islands.

These islands have no direct conservation authority oversight. 


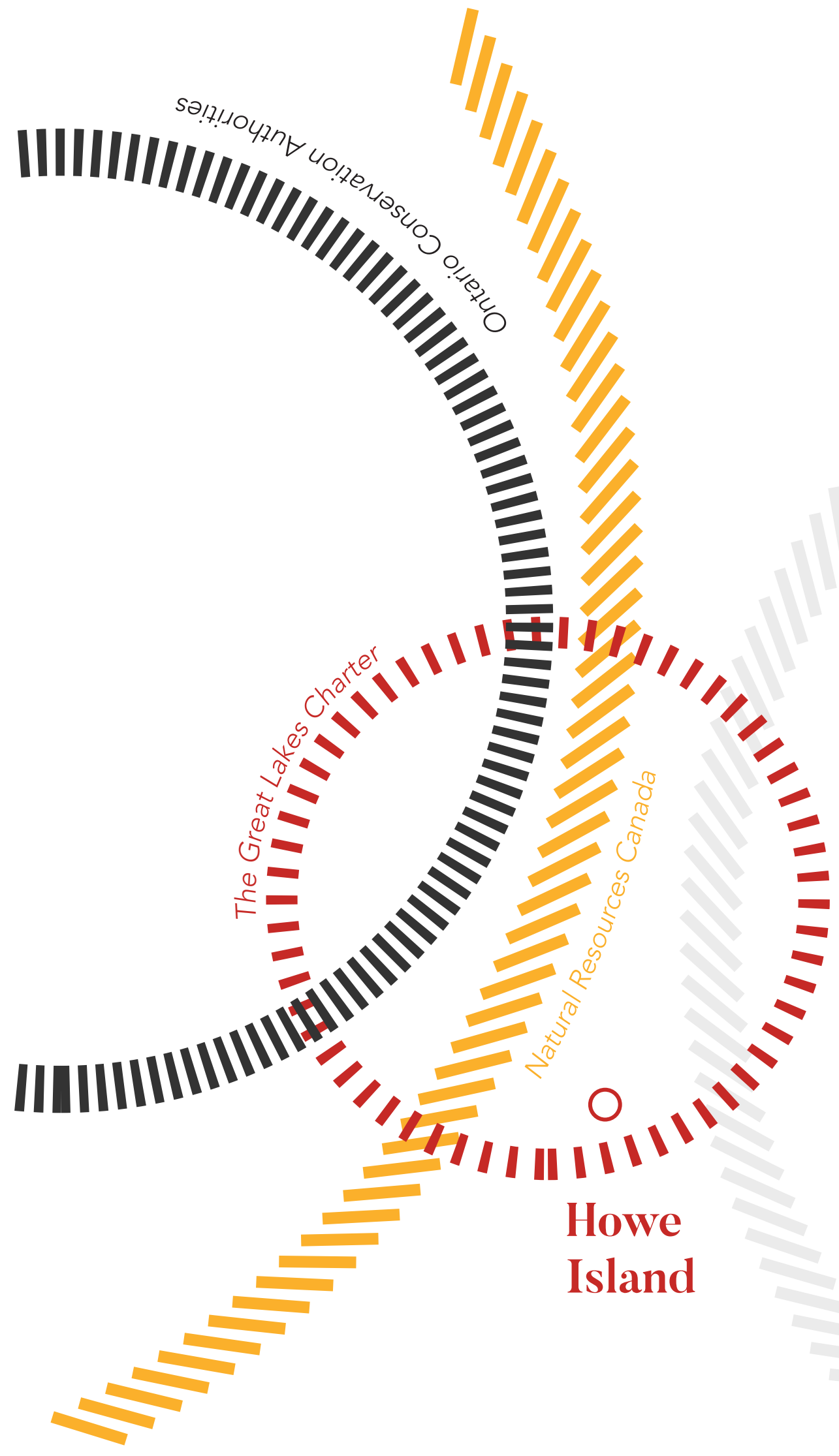




\section{Johnson Bay coastal wetland and forest}

Despite their lack of jurisdiction and oversight, the grouping of islands including Howe Island have been identified as areas of distinct biological and environmental importance. A report by the Nature Conservancy of Canada identifies 7 of the 911 islands in the region as key islands for biodiversity conservation(Bonnie L. Henson, Daniel T. Kraus, Michael J. McMurtry, 2010). Of these seven islands, Howe Island is the only one without any form of conservation authority jurisdiction, natural heritage designations, or Important Bird and Biodiversity (IBA) designations on it. Of the three largest islands, (the others being Amherst and Wolfe), it is also the only island without wind turbine energy projects, long term studies of which are currently underway to determine effects on migratory bird nesting patterns.

Despite the lack of concrete designation, the Johnson Bay Coastal Wetland and Forest area on Howe Island has been identified as both a Provincially Significant Wetland and a Life Science Area of
Natural Scientific Importance (ANSI). The close scrutiny of Johnson Bay's abuse through human impact will serves as the primary foil for this particular Instrument of Gaia. The history of the Carolinian forest, the galciofluvial soils of the marsh adjacent land, and the desolation of these soils inform an architectural project which prioritizes these voices in it's production as a means of storytelling. In doing so, the Johnson Bay Chestnut revival project becomes a nursery not just to the near extinct pride of the Carolinian Forest, but also a new, mindful ecopolitic where the harvesting, reaping, sowing and ruination of the visitor's centre, form memories located not just in site, but in time and season. 


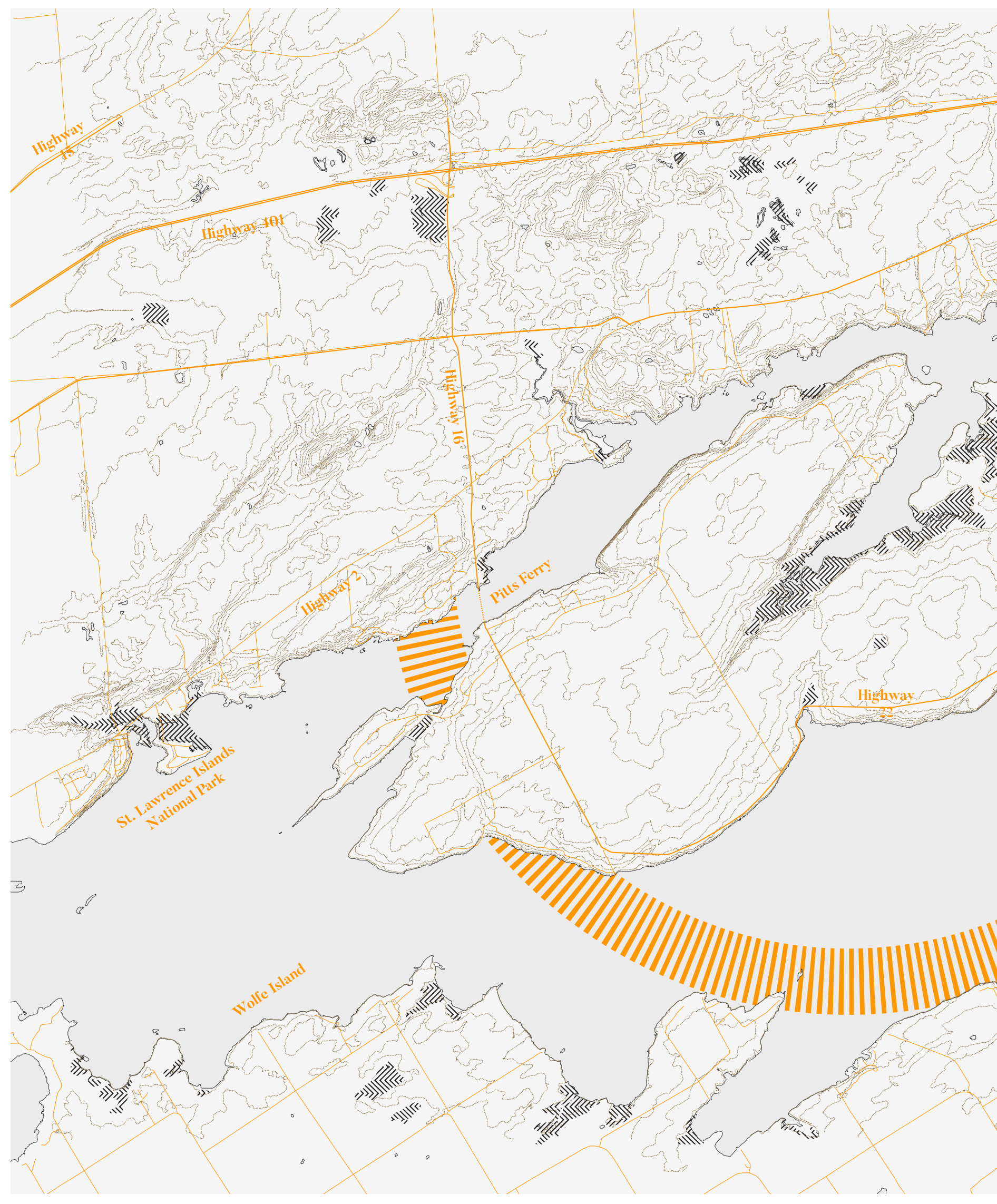




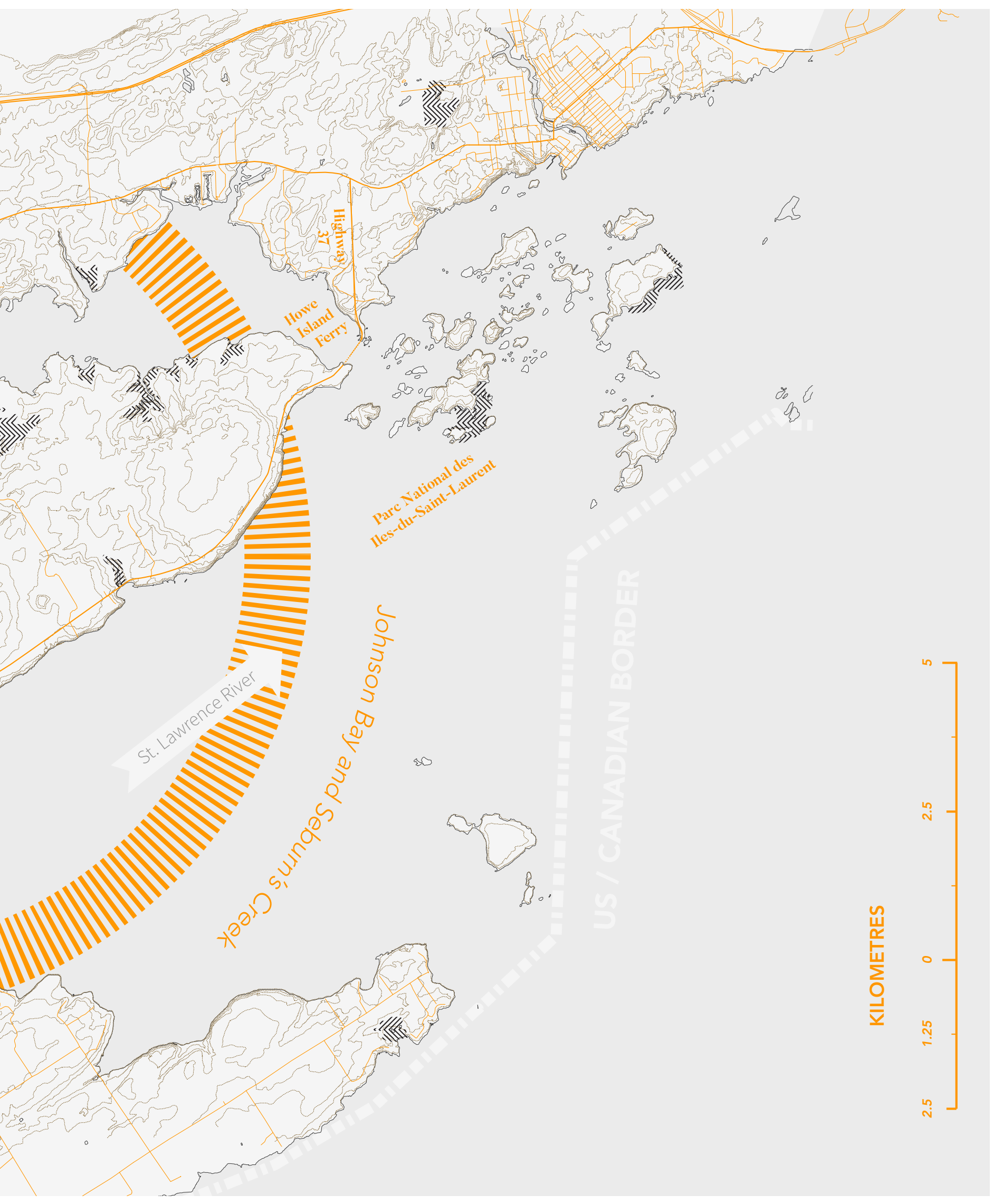

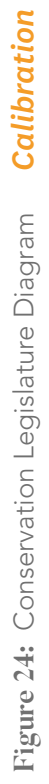



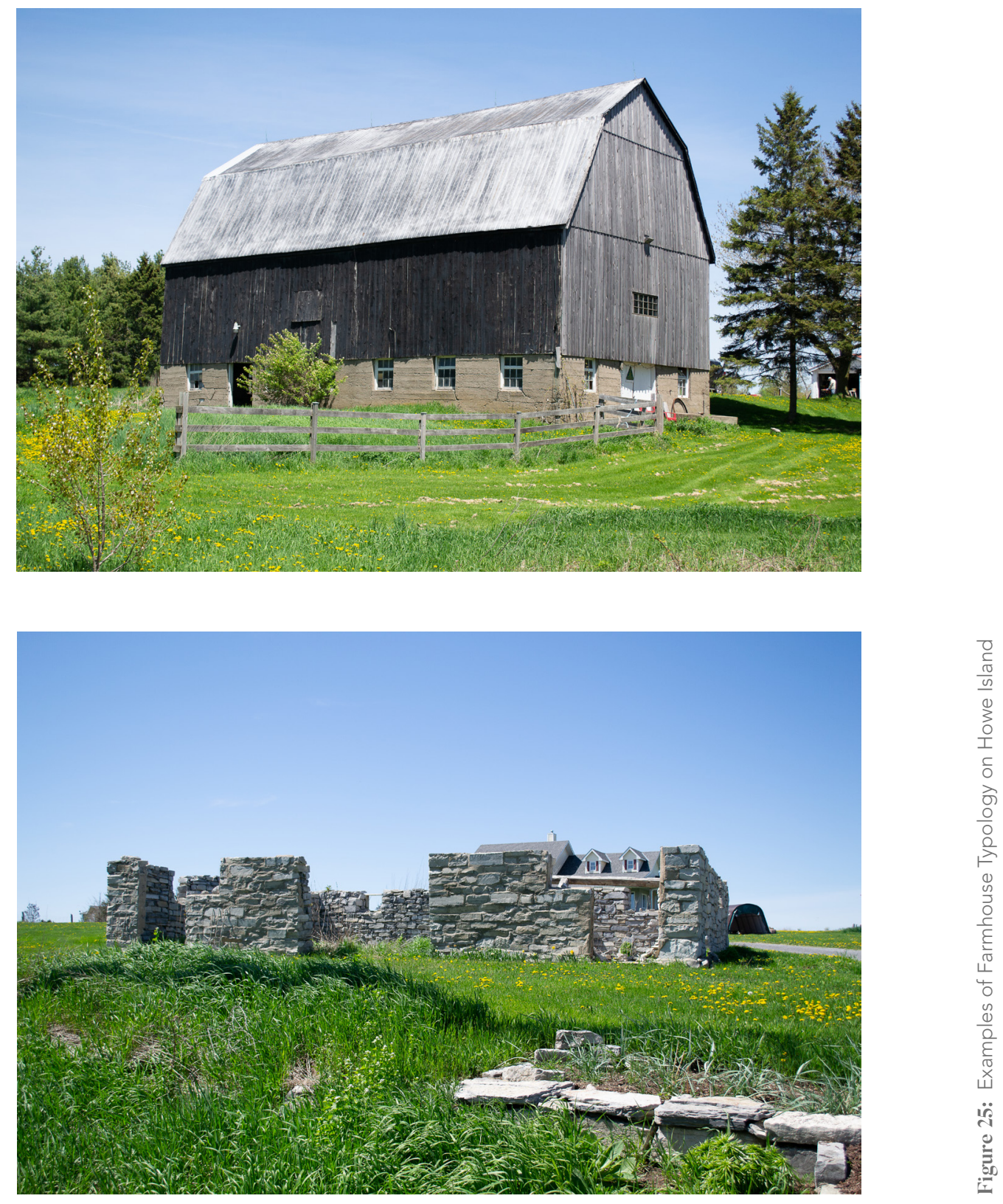


\section{Agro-Industrial Archetypes}

The production of agricultural land throughout Ontario dates back to Governor General John Graves Simcoe's plan for the then Upper Canada's development/ Following the American revolutionary war, crown sympathizers no longer welcome in America flocked by the ten's of thousands to the fledgeling settlements north of the Great Lakes, and a part of the rapid colonial development of these lands and infrastructure, and the assurance of it's new inhabitant's loyalties, was a survey, and a promise. Simcoe contracted out every surveyor in what would become Ontario to chart the lands and settlements to be given to newcomers, on the condition that they sign fealty to the crown under the governor general. These surveys for obvious reasons were not able to parcel lands due to specific conditions due to the shear volume of work to be done, and thus ontario's rectilinear grid of farmland as we know it was born. Up to the individuals to clear roads and their own lots. This agricultural history spread throughout Ontario also comes with the problems and issues of 

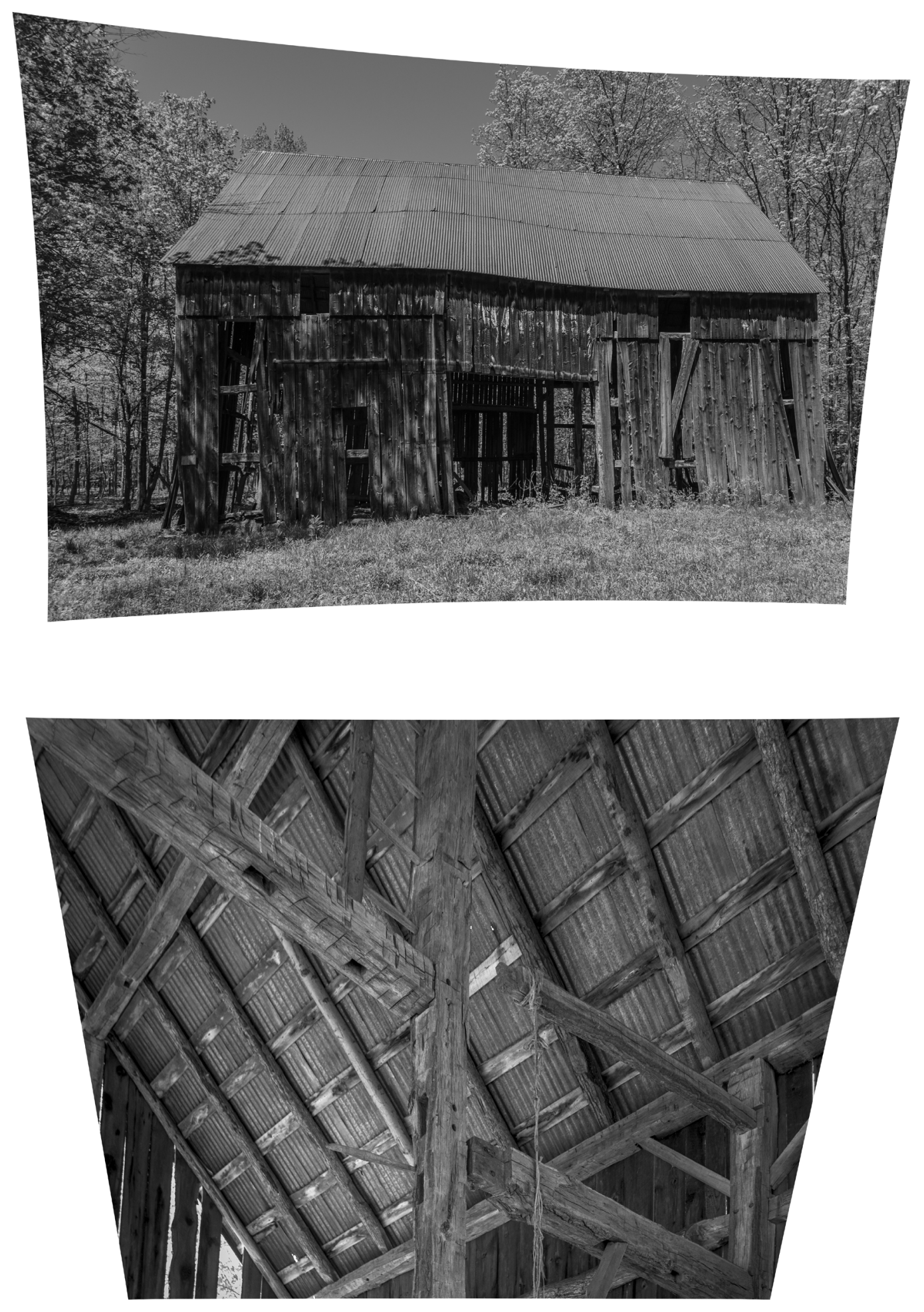
The archetypes of agricultural vernacular in Ontario, especially on Howe island are therefore taken into question as a design challenge. The very language of the driveshed, the barn, the silo, and the stone foundation so common to Howe Island, constructed with locally sourced timbers and stone, must be critically pivotted in the process of attempting to reconcile soil, tree, and wetland. These material operations will also become integral to the continuing operation of the Johnson Bay ecological armature. 


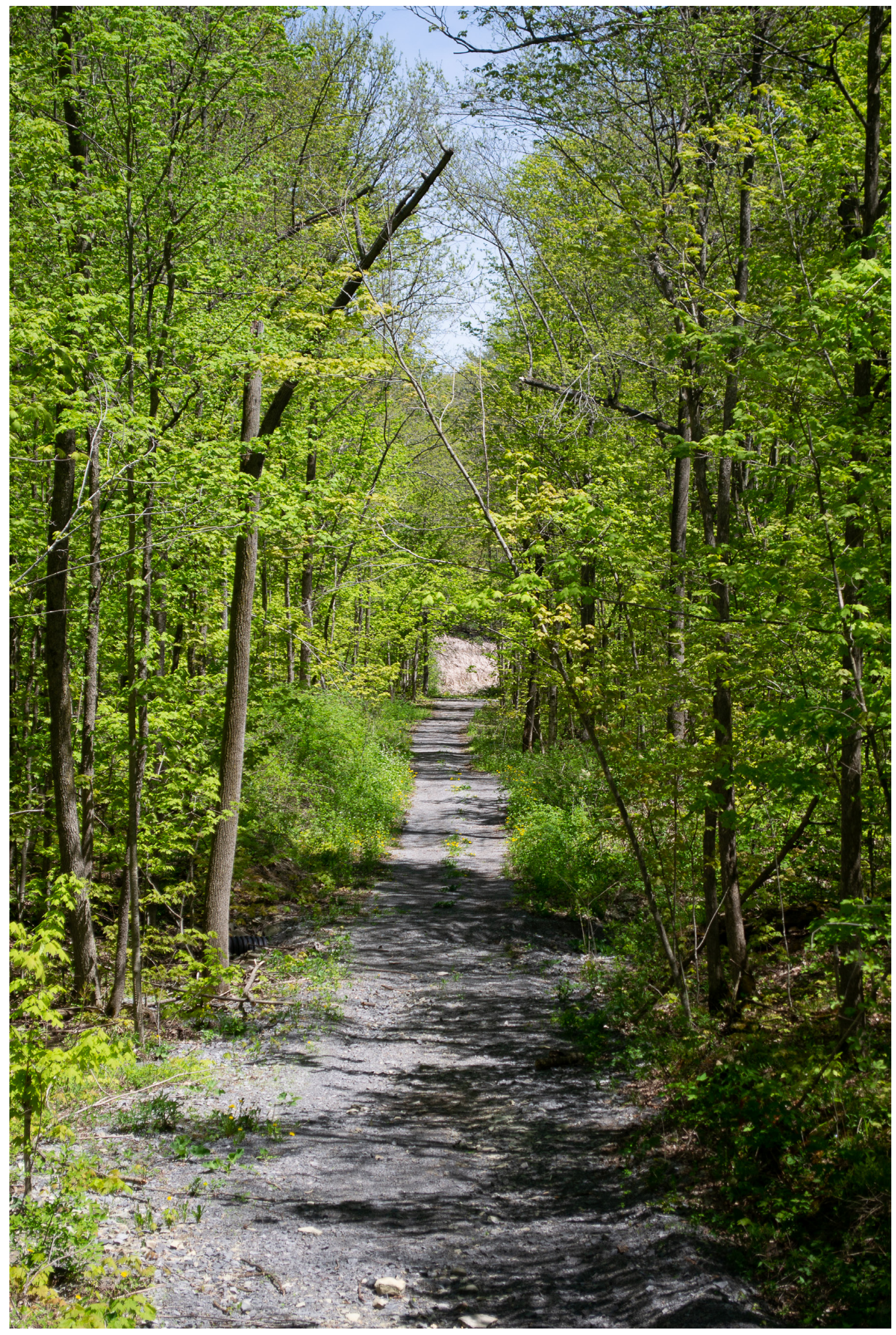




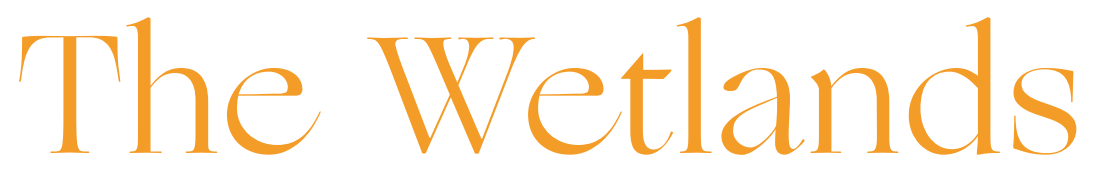




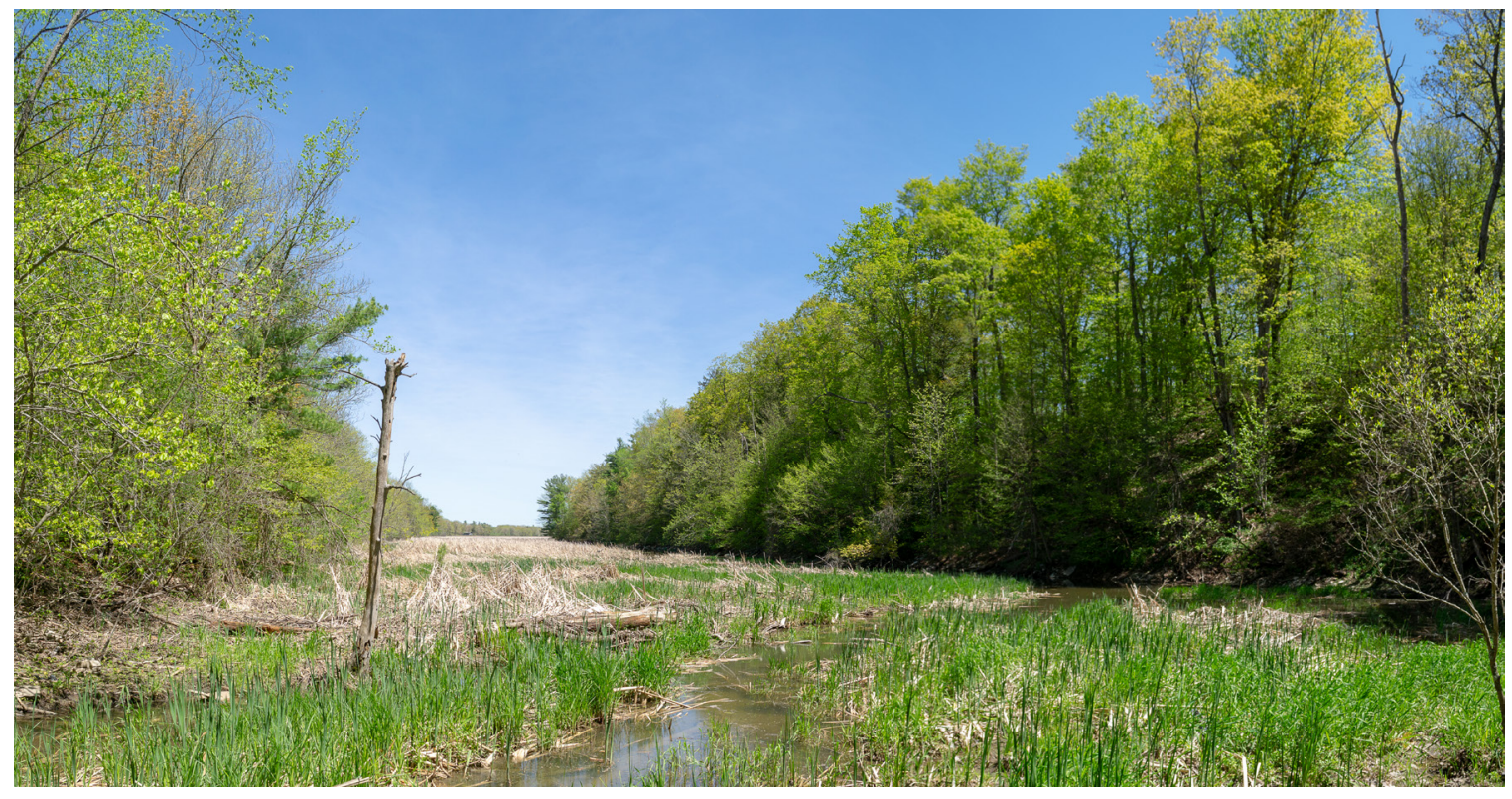



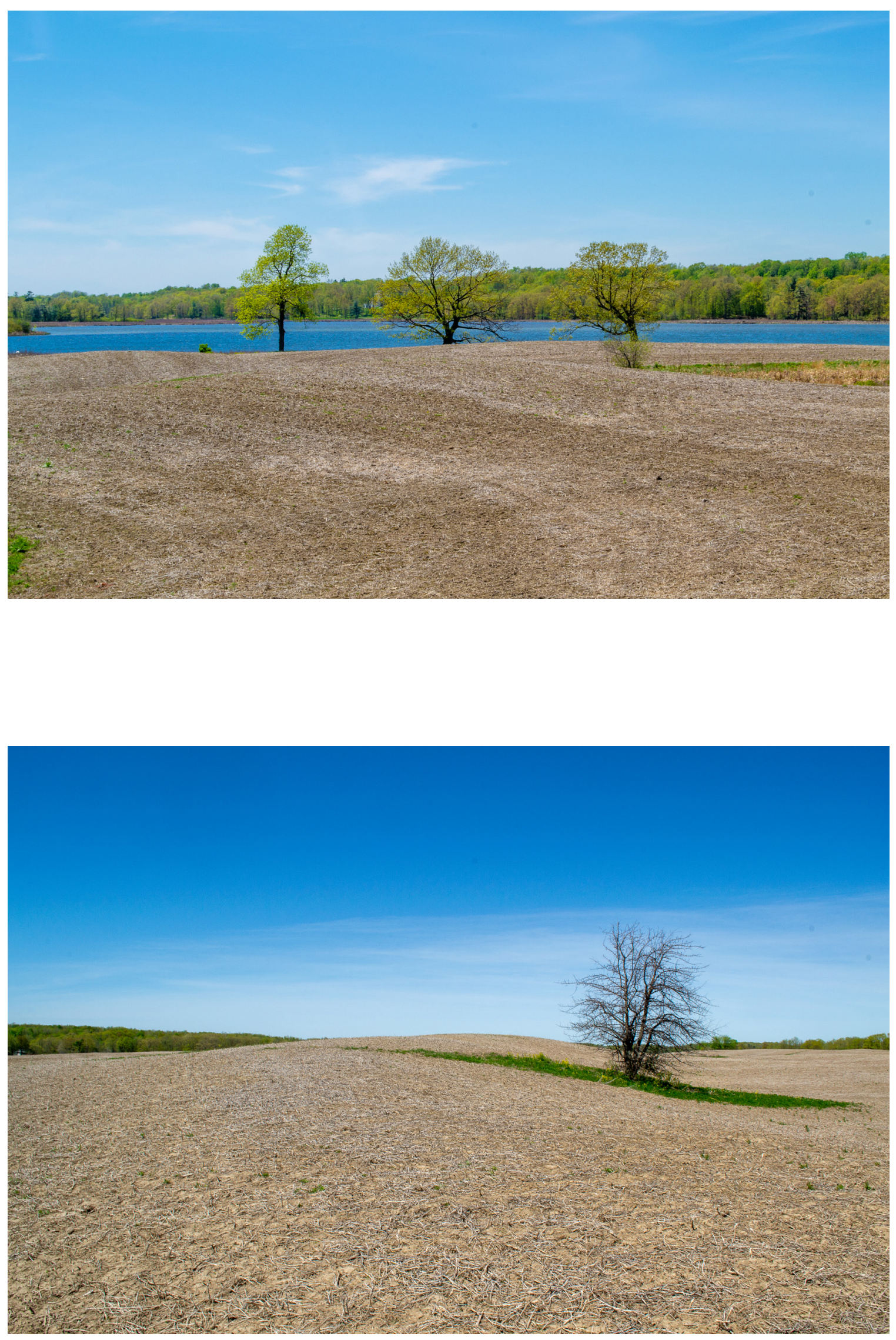

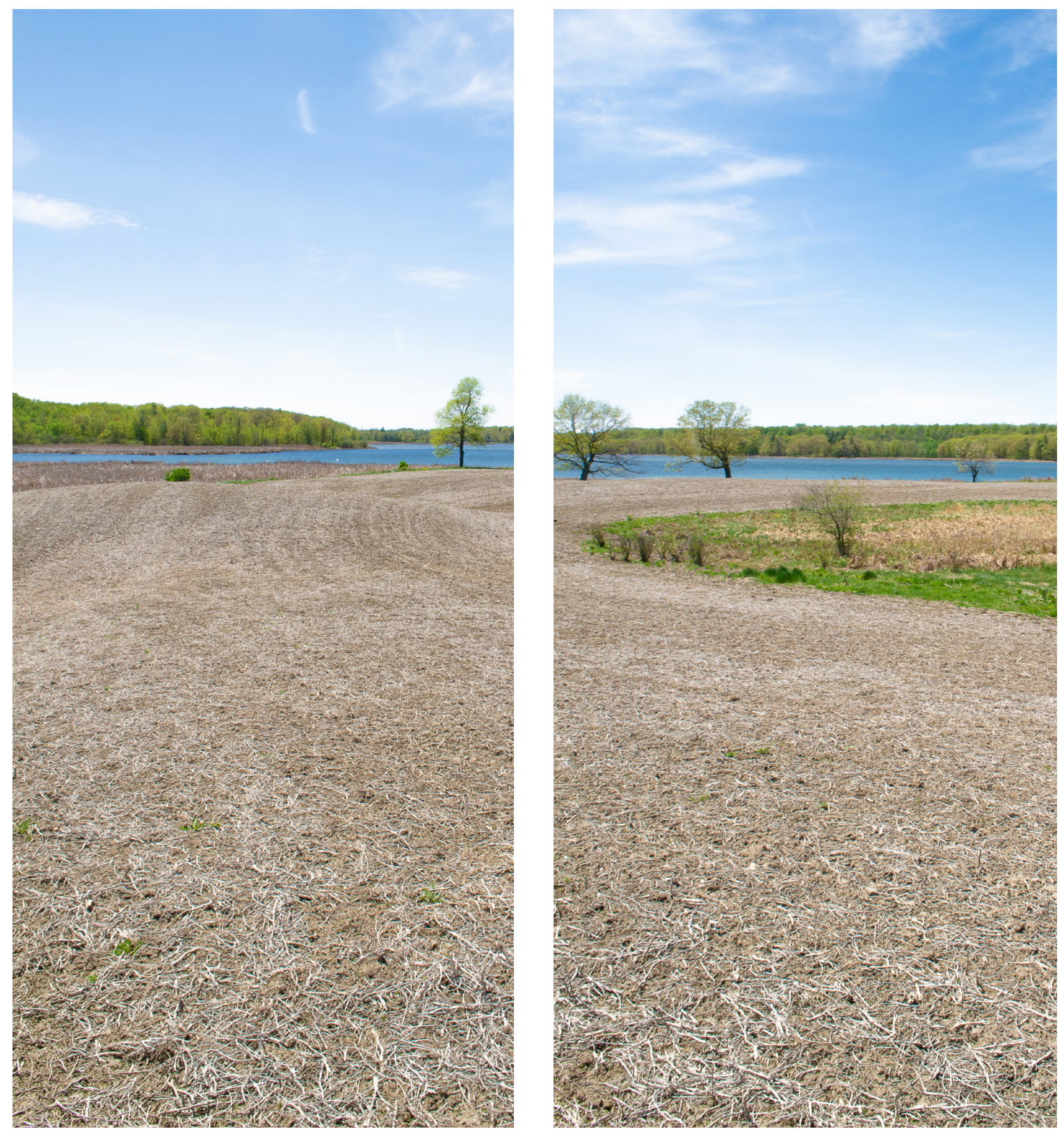

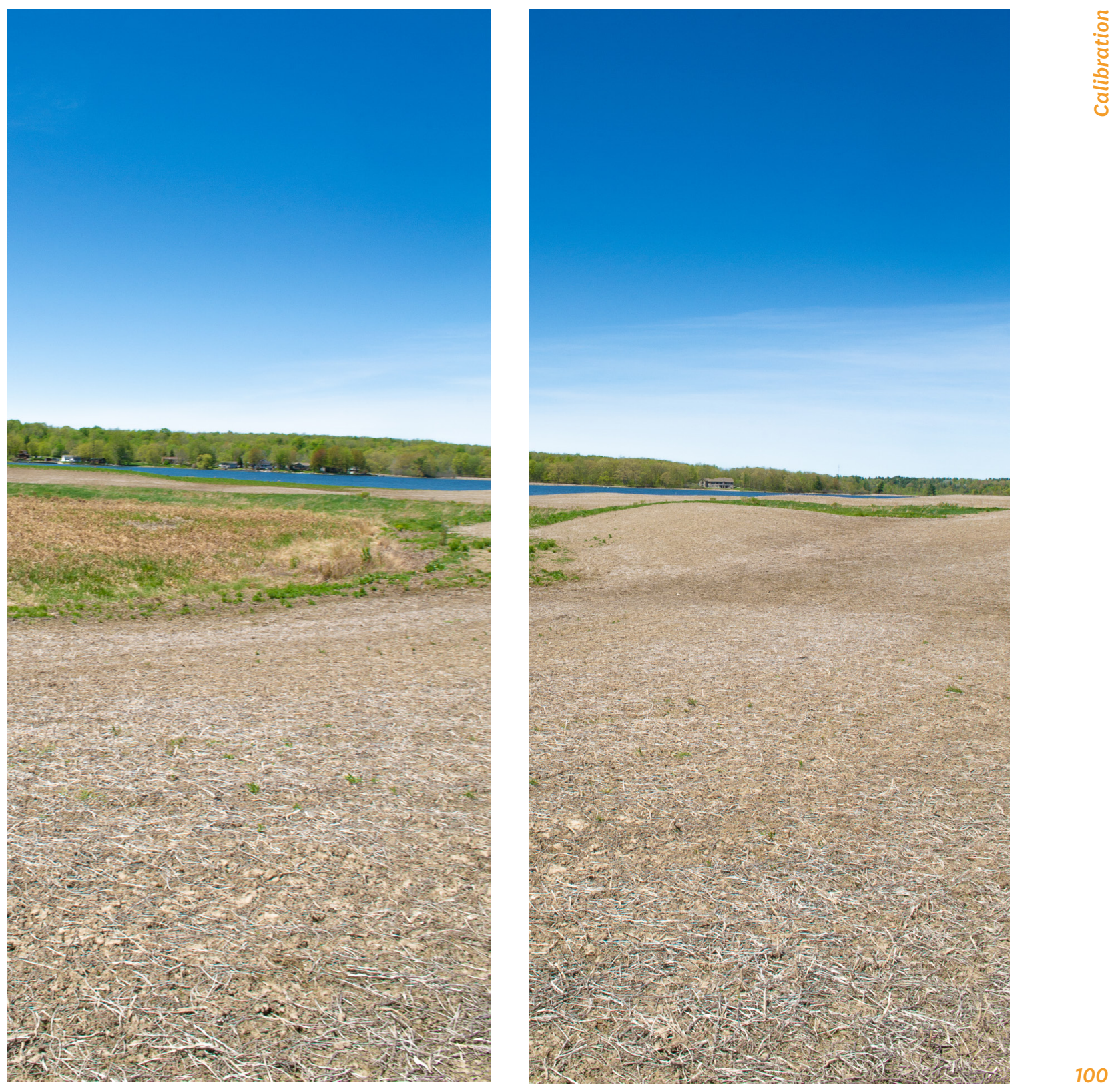



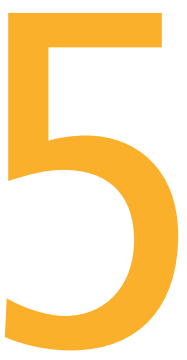

The Instrument 


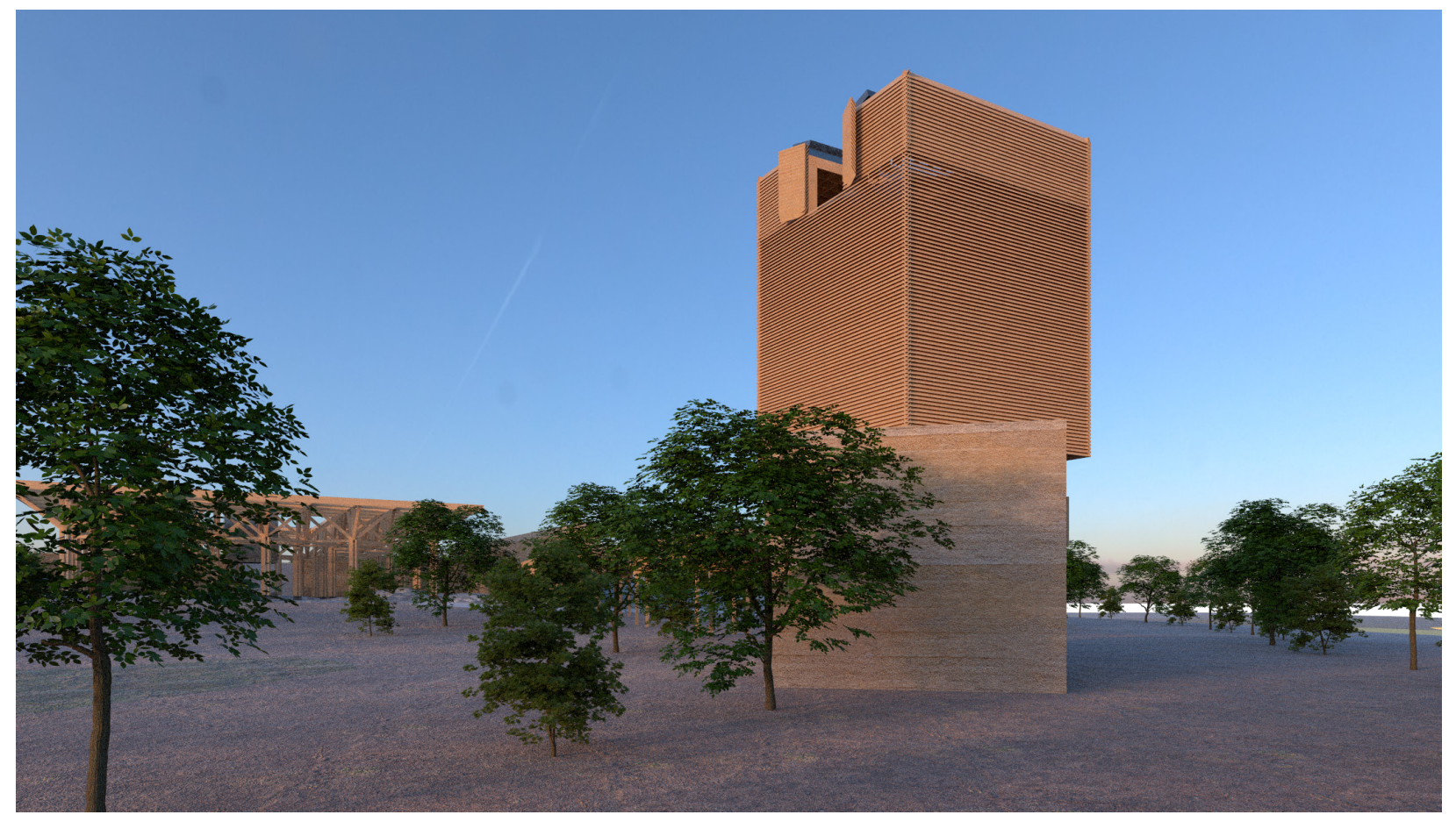




\section{Observatory, Nursery, Time Capsule}

Building a grammar from found materials, and applying this grammar to the language of traditional agricultural construction practices, the Johnson Bay Ecological projects seeks to apply the local simultaneously to the cosmological. For this ecological project, which seeks to test the reading of the American chestnut for long term rewilding in Ontario, first the inspection of soils must be completed.

The completion of these processes is executed in tandem wiht the construction of both reinforced and non-reinforced monolithic rammed earth construction, embedding the geological survey into the haptic and visual language of the visit. In order to track the success of the batches of trees grown, a security of program must be provided to ensure research can continue. Here, the domain of architecture as the bridge and communicator of the cosmos becomes integral to the survival of the chestnuts. The same observation tower which would allow regular panoramic photography and surveys to be completed will also become a treetop observatory, using Johnsons Bay's status as a dark sky site. In theis way, the visitors to the site flocking en masse for the autumn pawpaw and chestnut harvest, the only of it's kind in the nation, will also have a chance to turn their gaze upwards, and ponder the greater ramifications of human impact on this once pallid soil. These two purposes are bridged and conjoined by a third programmatic element, a canadian chestnut council sponsored fine arts woodworking apprenticeship program. When several young fine carpenters are chosen each year to be tutored under the council of a master, they will learn to care for the chestnuts, diagnose blight, and make use of the stricken trees in the production of new cultural objects and works which will carry the legacy of the Johnson Bay Chestnuts further through the furniture and joinery they provide. 

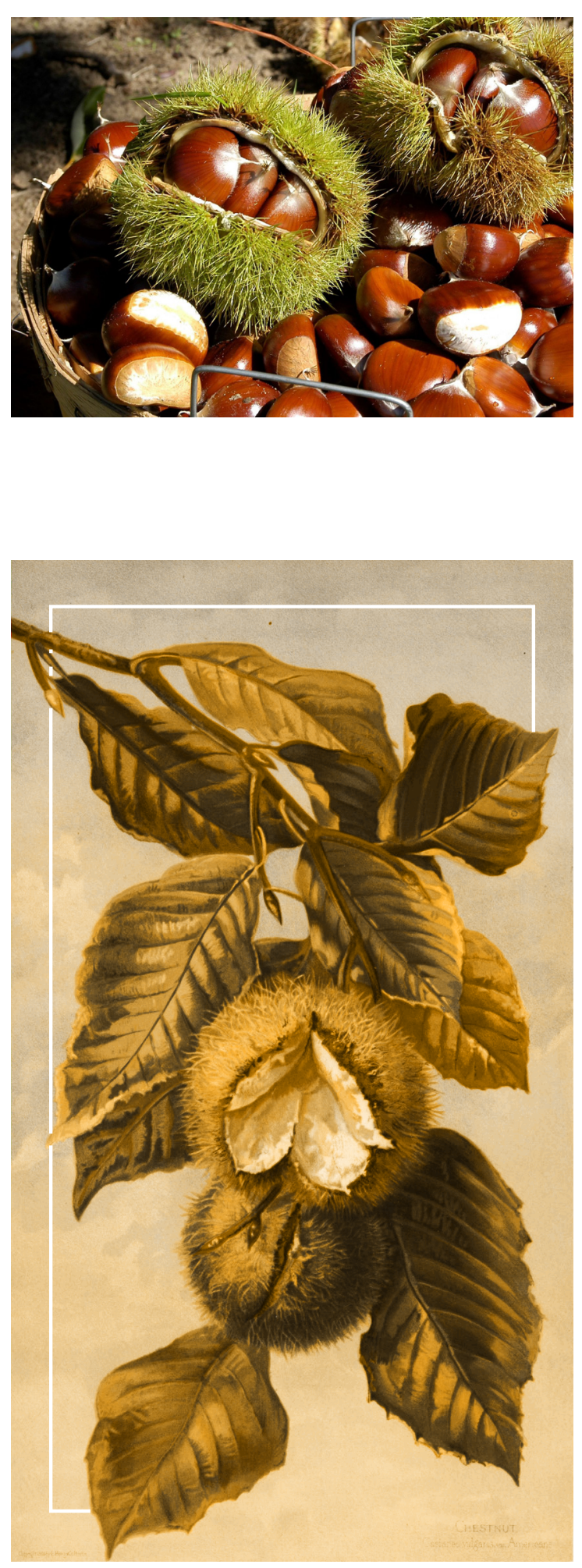


\section{the American Chestnut}

\section{Castanea Dentata}

Traditionally an enormous stock of Carolingian forests throughout America, and a consistent nutrient and allelopathic source for the surrounding forest and wildlife, blight introduced from import of the Chinese Chestnut eradicated an estimate of 4 billion American Chestnuts, driving it to wild extinction from which many areas never recovered. However, patient cross-breeding and exposure have led to recent 6th generation stock which requires testing, and Howe island's isolation from mainland, as well as the traditional Carolinian biomes might provide the perfect location.

Spacing - 25-30ft. between trees

Fruit Production - 5 years after planting

Harvest Time - Mid-September to Mid-October

Winter Treatment - White Latex Paint (Diluted by 50\% to protect from sunscald 

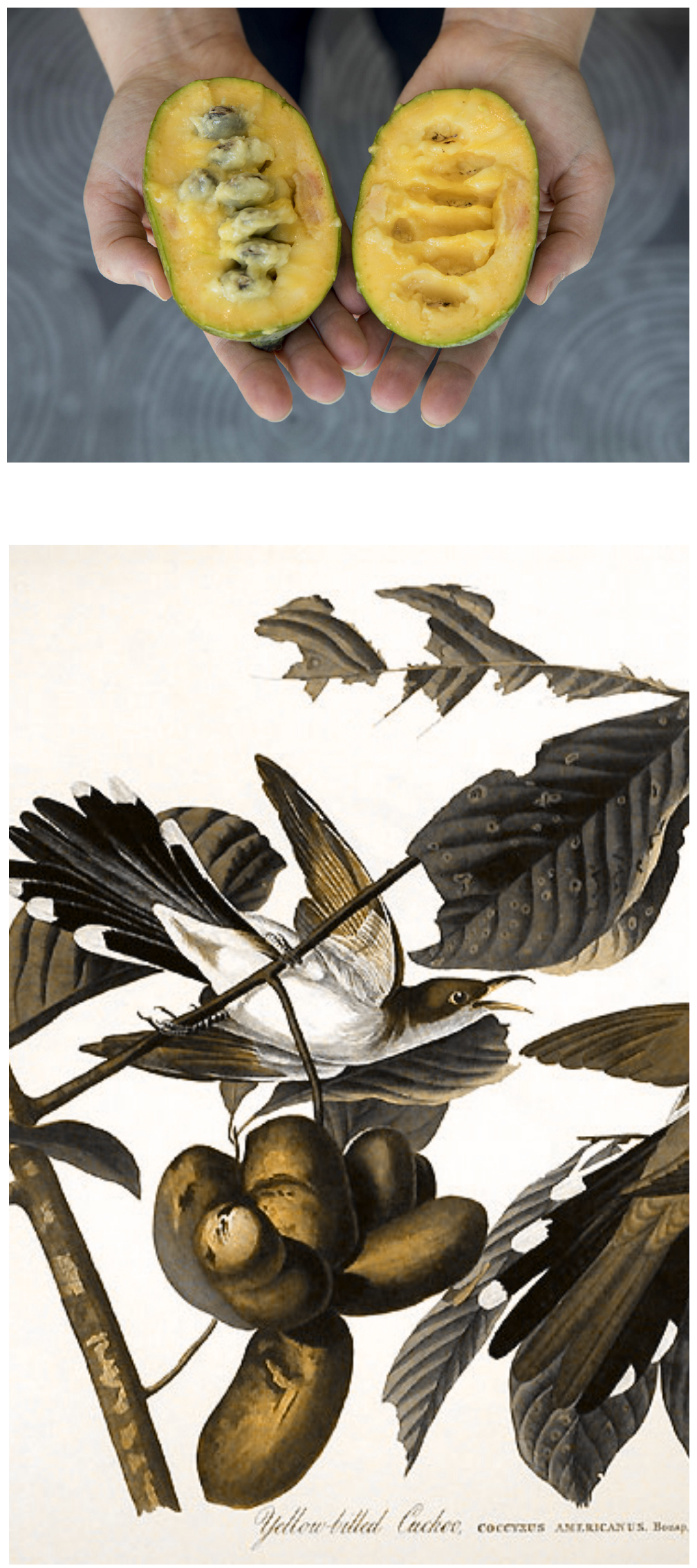


\section{the Paw Paw}

\section{Asimina Triloba}

The only native fruit to North America, the Pawpaw tastes like a mix of Mango and Banana, and with avant-garde ethics towards food production is experiencing invigorated interest in Ontario food markets. Chilled like a custard or a part of ice cream, the appeal of the Pawpaw not only as a novelty, but as a treatment of globalist tastes within regionalist means of production provides a metaphor for a responsible anthropogenic future.

Spacing - 10ft. between Pawpaws

Fruit Production - 6-7 years after planting

Harvest Time - Mid-August to

Mid-September 


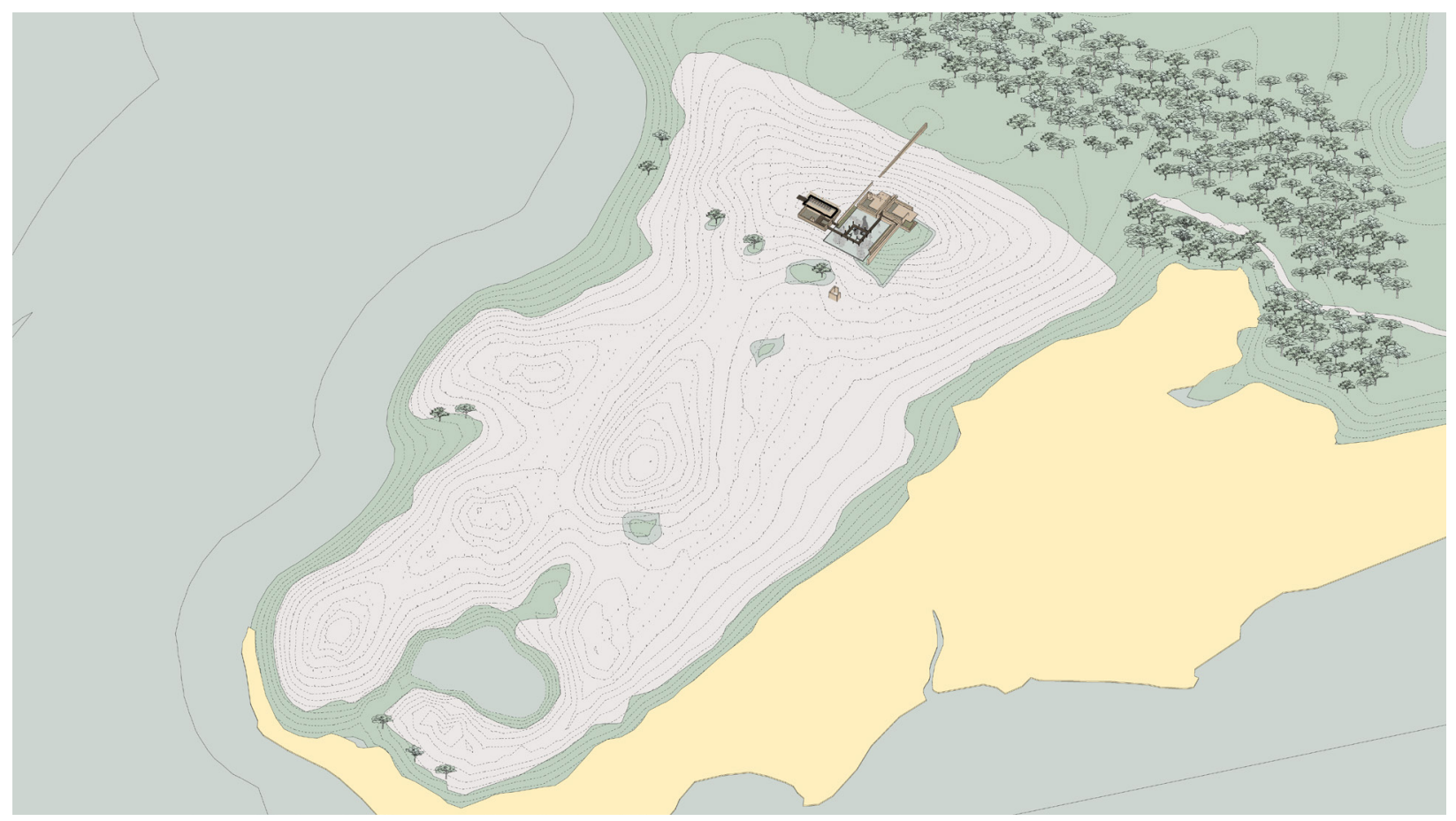


Gaiac operations commence, the remnants of the agro-industrial landscape are dissected, operated on, a careful incision made for diagnosis while the scar tissue itself is repurposed into plasticizing the history of this geological body. The postoperative delirium of a traumatic ecological past is carefully re-acclimatized through hints, measurements, adjustments in treatment, and a slow bedside manner requiring extended presence. During this period adjustments in genetic planting material, soil indoctrination and nourishment follow. 


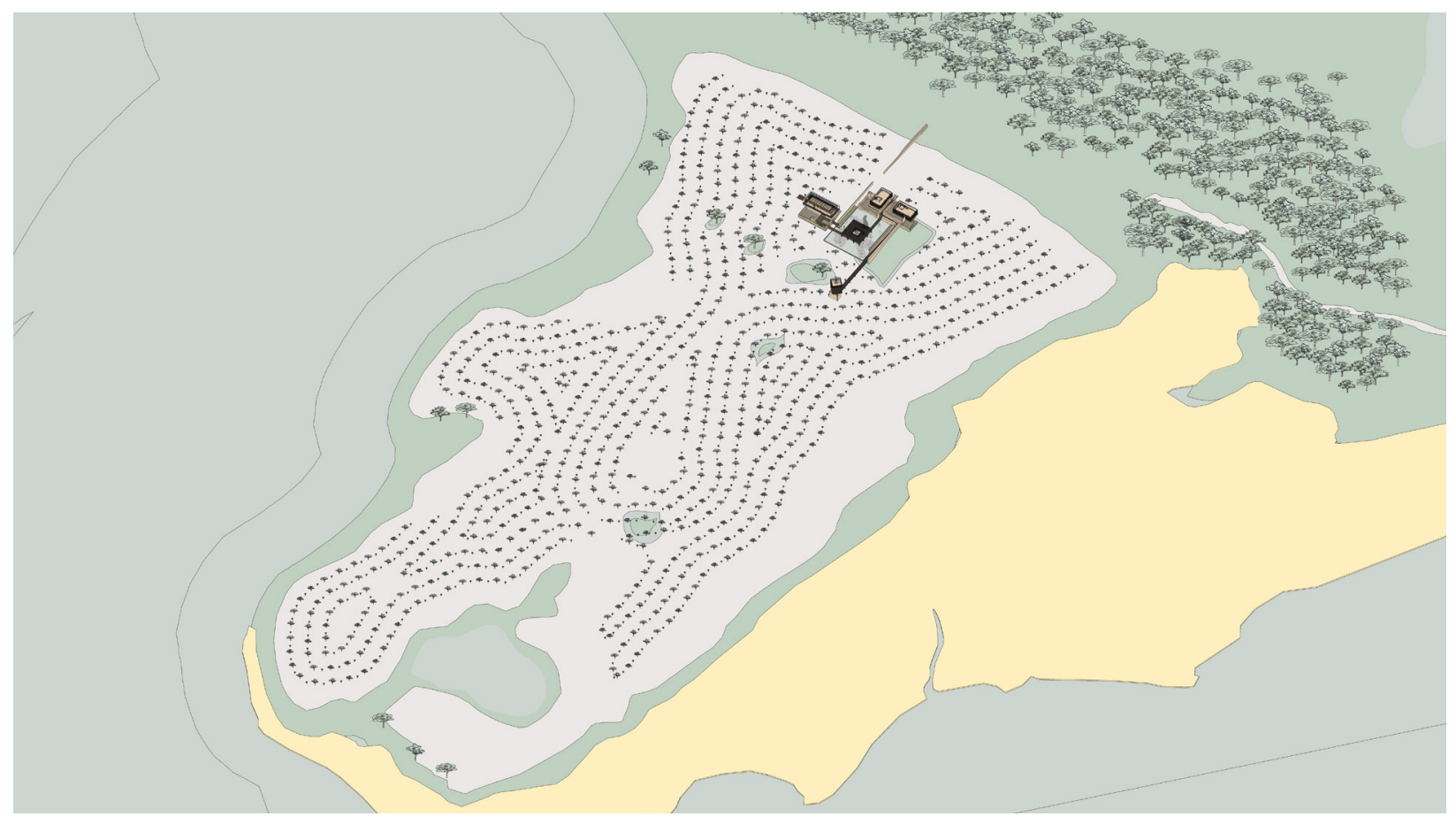




\section{harvest}

Fruits come to bear on mass, bushels

of sweet fruit in a bedding of clustered

burrs indicate the returning breath of Gaia

on site. Spanning from mid-August to

mid-September for Paw Paws, and until

mid-October for Chestnuts, the annual

Johnson Bay Harvest Festival draws

agro-tourism and provides an impetus

to foster social, intimate connections

with the once ravaged land. As families

and friends wander through the trees,

collecting the smells of native fruits and

nuts of the Carolinian forest, they also find

themselves encountering an architecture

wholly unique in the orchard's groves.

The combination of intimate memories

of family, the sequence of the ferries, and

the rammed earth storage, packaging

and curing silos will create richly sensual

memories of a land whose once destitute

soils have been repurposed in an act of anthropic regeneration. 


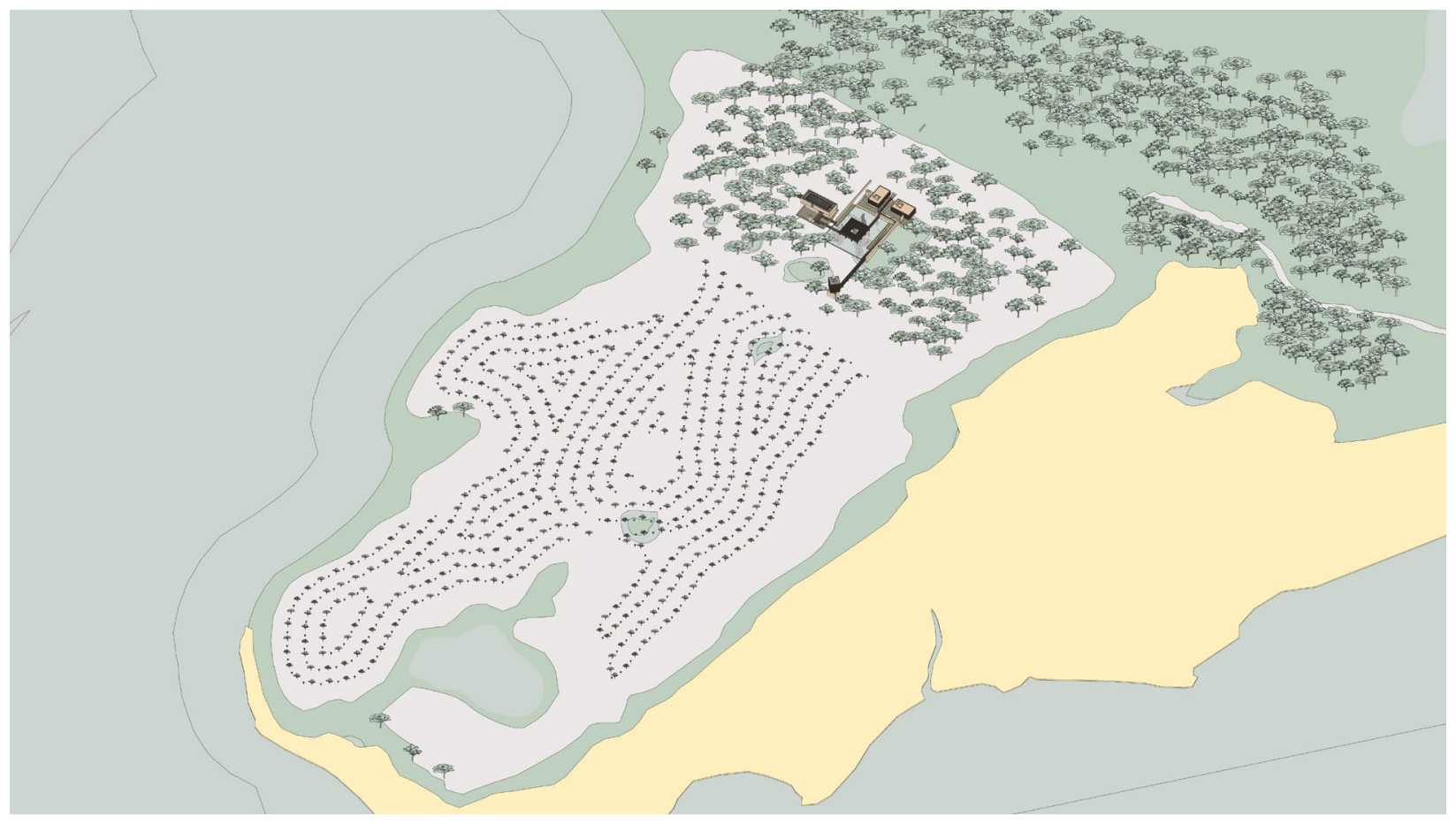




\section{reaping}

An iron lung release begins with the reaping. The fragile fall to blight, while the strong soar. Those who fall short of the bar are culled, allelopathic root systems beckon a Carolinian curtain to descend from the east. From here forward predictions grow hazy, and only observation and documentation can predict what conversations will be had with land. Meanwhile, the prophetic return of industry rears its head one last time.

Those chestnuts fallen become an intrinsic part of an artist-in-residency program, where the site is transformed into a workshop for sculpture and craftsmanship, and the production of mnemonic objects, carrying the spirit of Johnson Bay with them as furniture, art pieces, and eventually, heirlooms. 


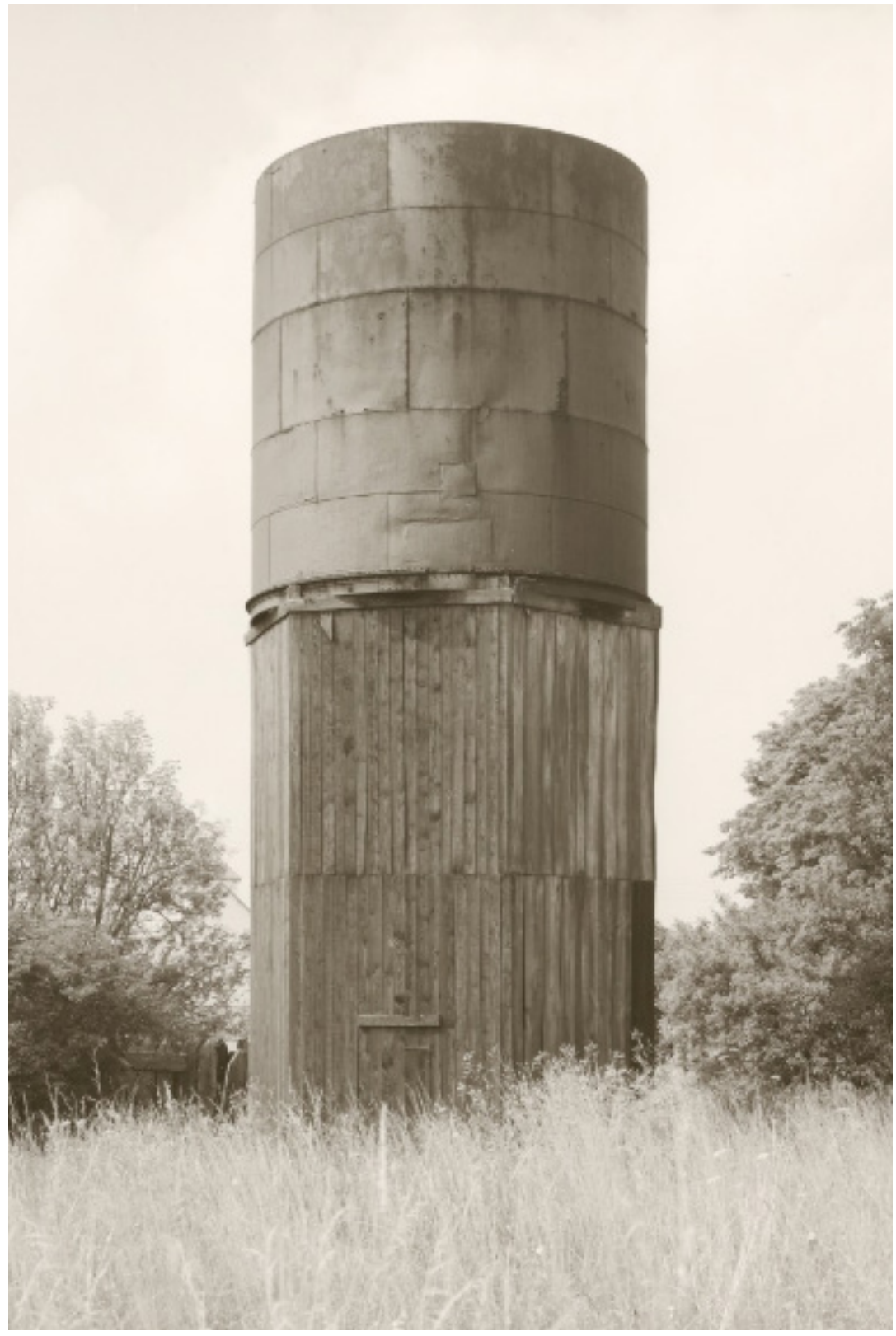

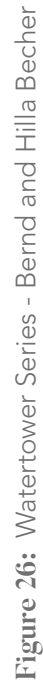




\section{ruin, continuation.}

With the Johnson Bay Forest Restoration project geostory nearly complete, and the slow rejuvenation of the once pallid soil complete, the time has come for human control on the site to relax. As the rammed earth forms and chestnut clad residencies degrade, decay, and patina over time, the Carolinian curtain sweeping over the site to fill the gas between the chestnuts and pawpaws will overtake these unique forms. As earth silo walls wash in the rain, architectural form transcends pure human purpose and takes on the authorial intent of Gaia. In this, the observation platforms ever so slightly above the treetops which once provided survey points to arborists, an Instagram-able selfie spot, have completed the gradated transition from a point of scientific observation, to a poetic one. The sites transition from a place of agro-industrial ruin into a dedicated reserve for Gaia is complete. 


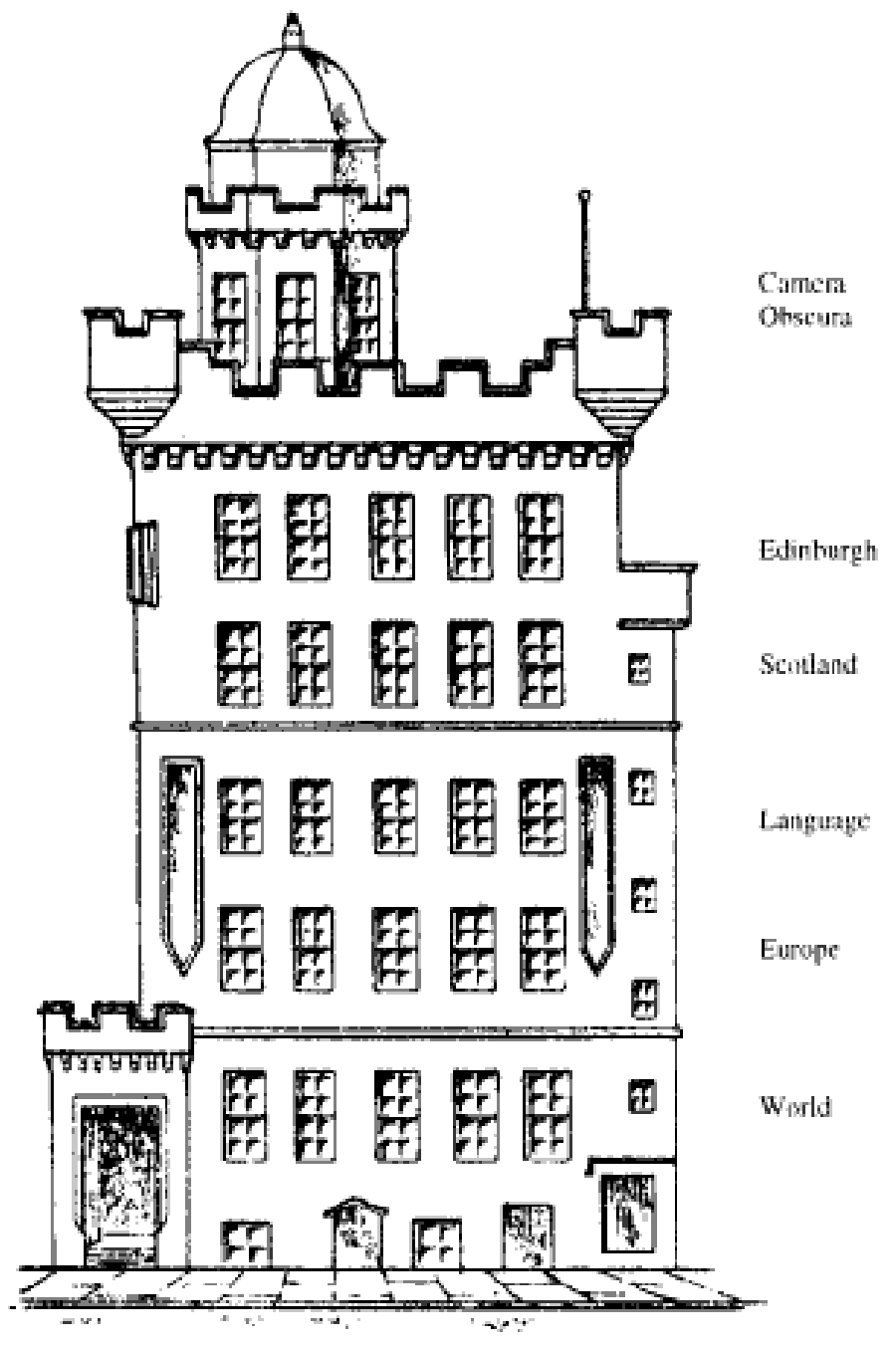

FIGURE 1. Diagrammatic elevation of the Outlook Tower (after P. Boardman, The Worlds of Patrick Geddes, London, Routledge and Kegan Paul, 1978) 


\section{The Observatory}

Patrick Geddes' Outlook Tower provides an example of how the cosmos, the regional and the local can be blended through the stacking of the program, and the resulting intermingling between jurisdictions of work through which ideas are exchanged. While his tower represents a strictly urban, vertical hierarchy, the johnson bay site demands a different approach.
"What then is an Index Museum? First of all, more than an ordinary museum it is not only an Encyclopaedia but an Encyclopaedia Graphica. That is, we may think of it as an Encyclopaedia of which the articles may be imagined printed separately, and with their illustration and maps condensed and displayed as an orderly series of labels; labels to which specimens are then as far as possible supplied; so that over and above the description, the image, the interpretation of the thing, you can see the thing itself in reality, if possible, or in reproduction or model as the case may be."

Patrick Geddes 


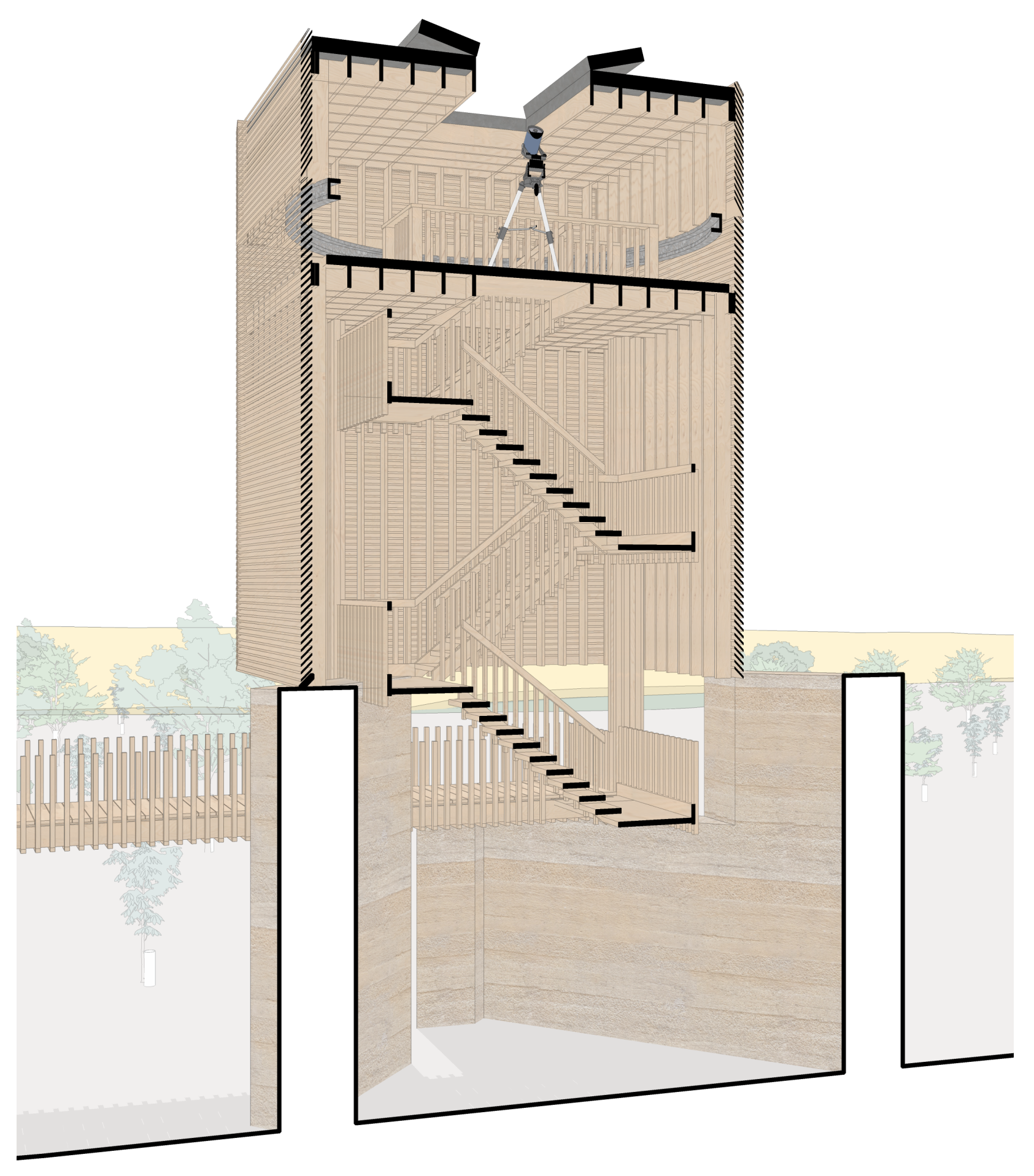


In the case of the on site, operable Observatory, a Meade computer operated telescope sits atop a timber tower whose final level can be rotated freely via a rack and pinion system. This observatory also layers the aerial surveying and infrared photography required to diagnose and assess the health of the American Chestnuts in perennial surveys. 


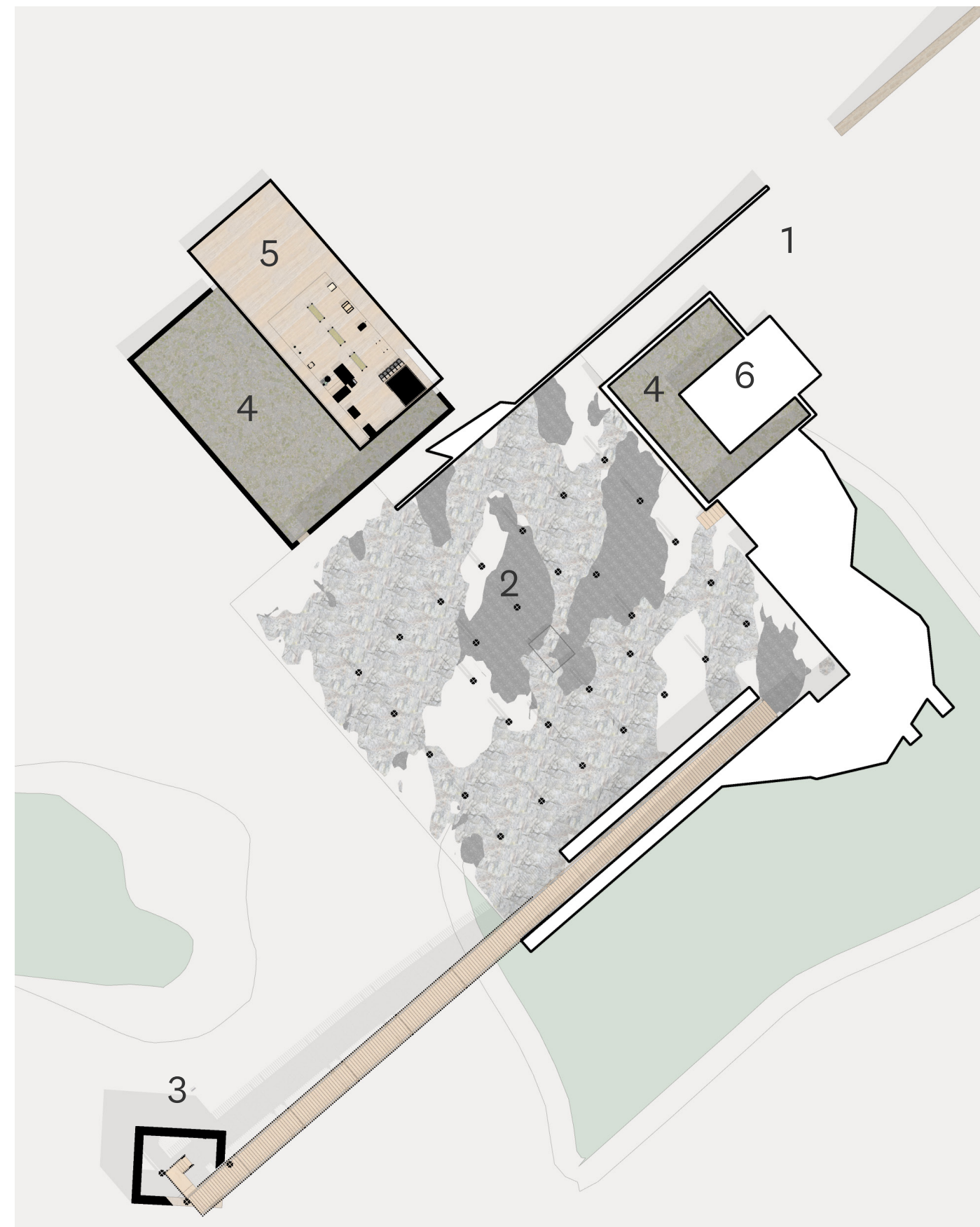




\title{
Main Floor Plan
}

\author{
Main Entrance \\ Bedrock Courtyard \\ Observatory Tower \\ Courtyard and Washrooms \\ Timber Shop \\ Residency Quarters
}

A central courtyard organizes the plan

around the excavated bedrock where the soils have been harvest for the rammed earth construction. In roasting chestnuts, consuming pawpaw ice cream, and sharing words with the carpenters in residence, one has the chance to connect with a multitude of timescales across decades of growth, and millenia of seismic compression. 


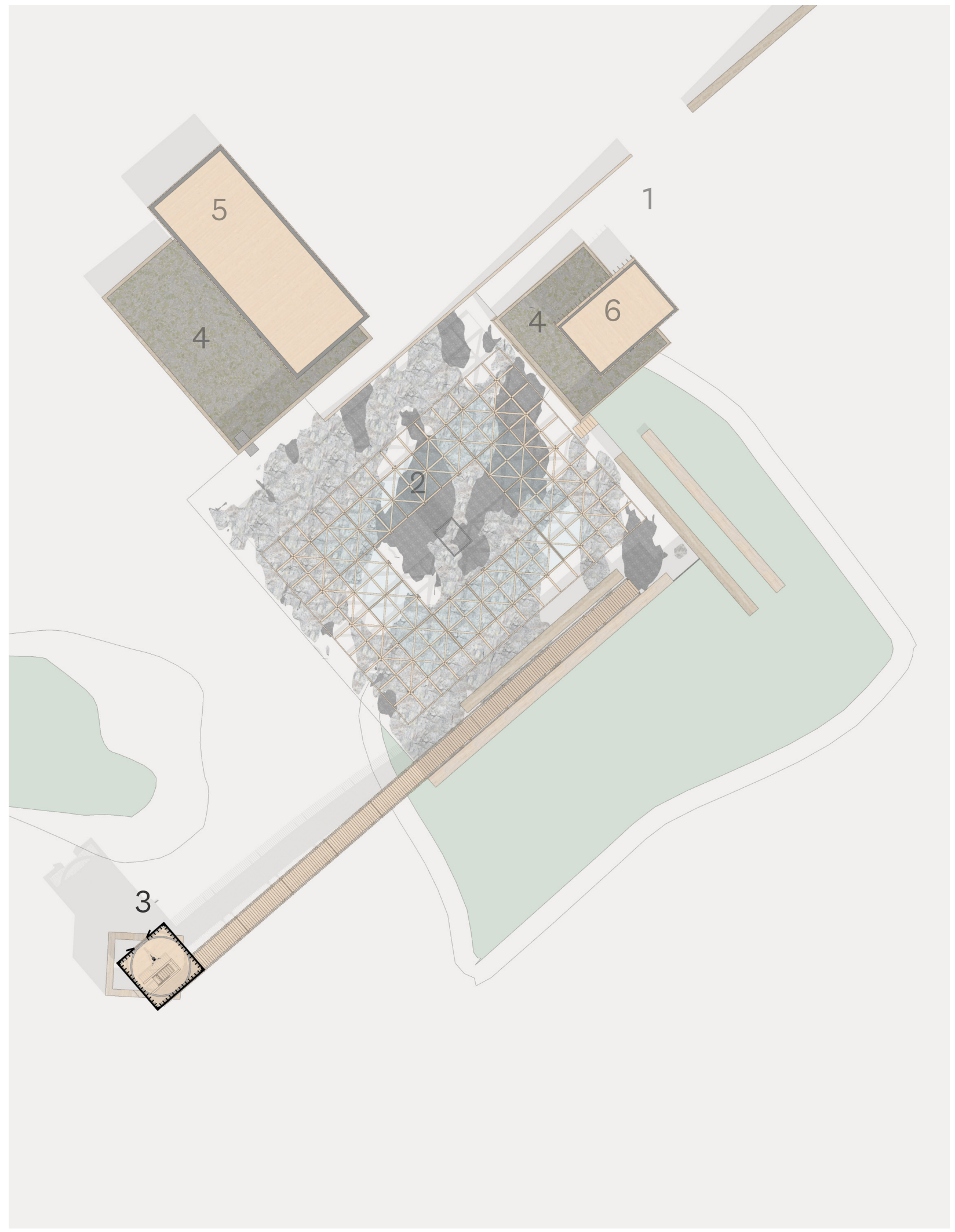




\title{
Tower and Observatory Plan
}

\author{
Main Entrance \\ Bedrock Courtyard \\ Observatory Tower \\ Courtyard and Washrooms \\ Timber Shop \\ Residency Quarters
}

Sited at the highest point of the Bay,

the centre of operations will be slowly

engulfed by the growing pawpaws and

chestnuts, until the only visible indicators

ofit's presence from the entrnace are a

protruding bare earth wall, and the faint

glimples of a tower through the treetops. 


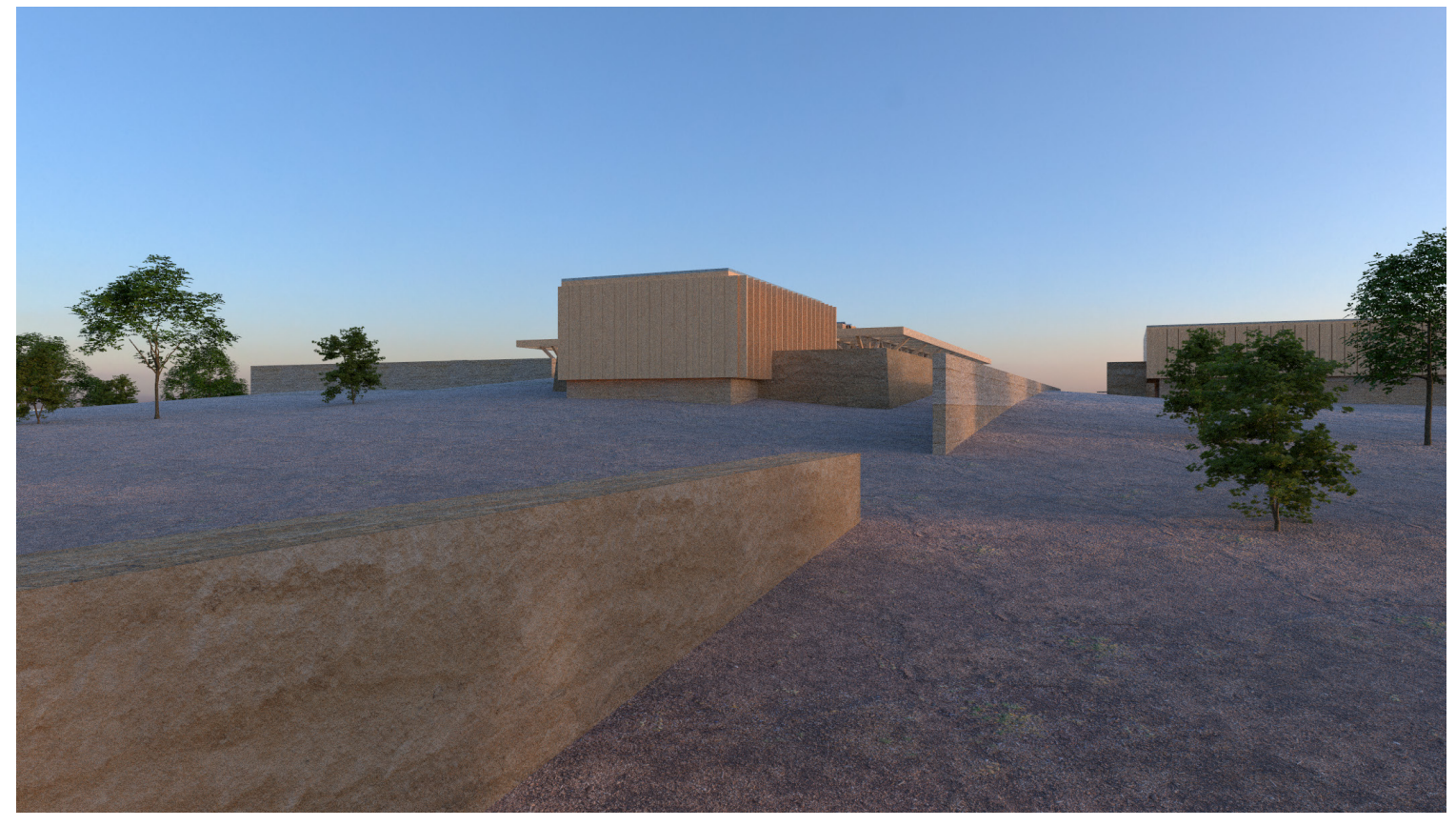




\section{Entrance and Courtyard}

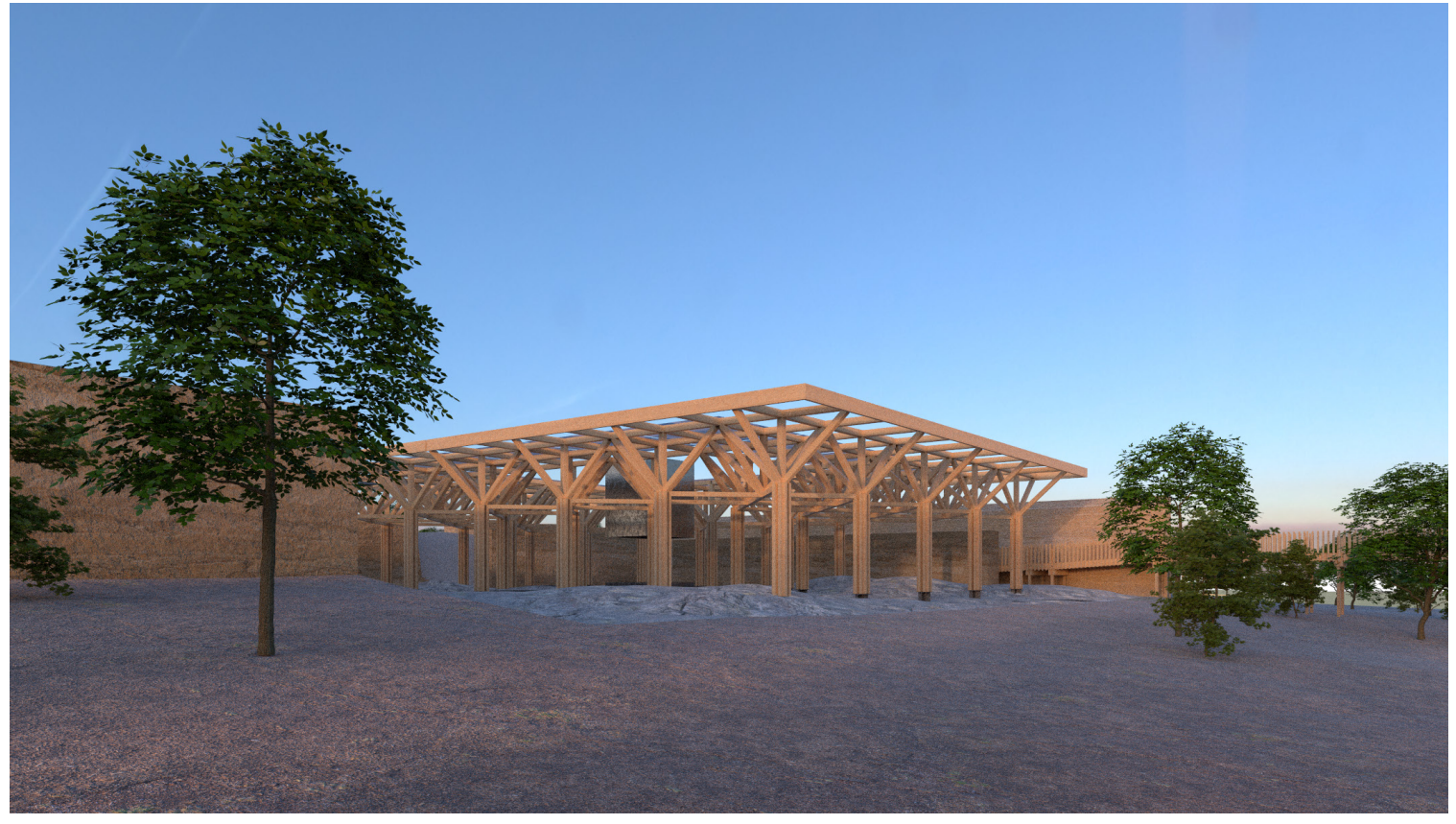

Pictured: 10 years of growth, two planting phases elapsed. 


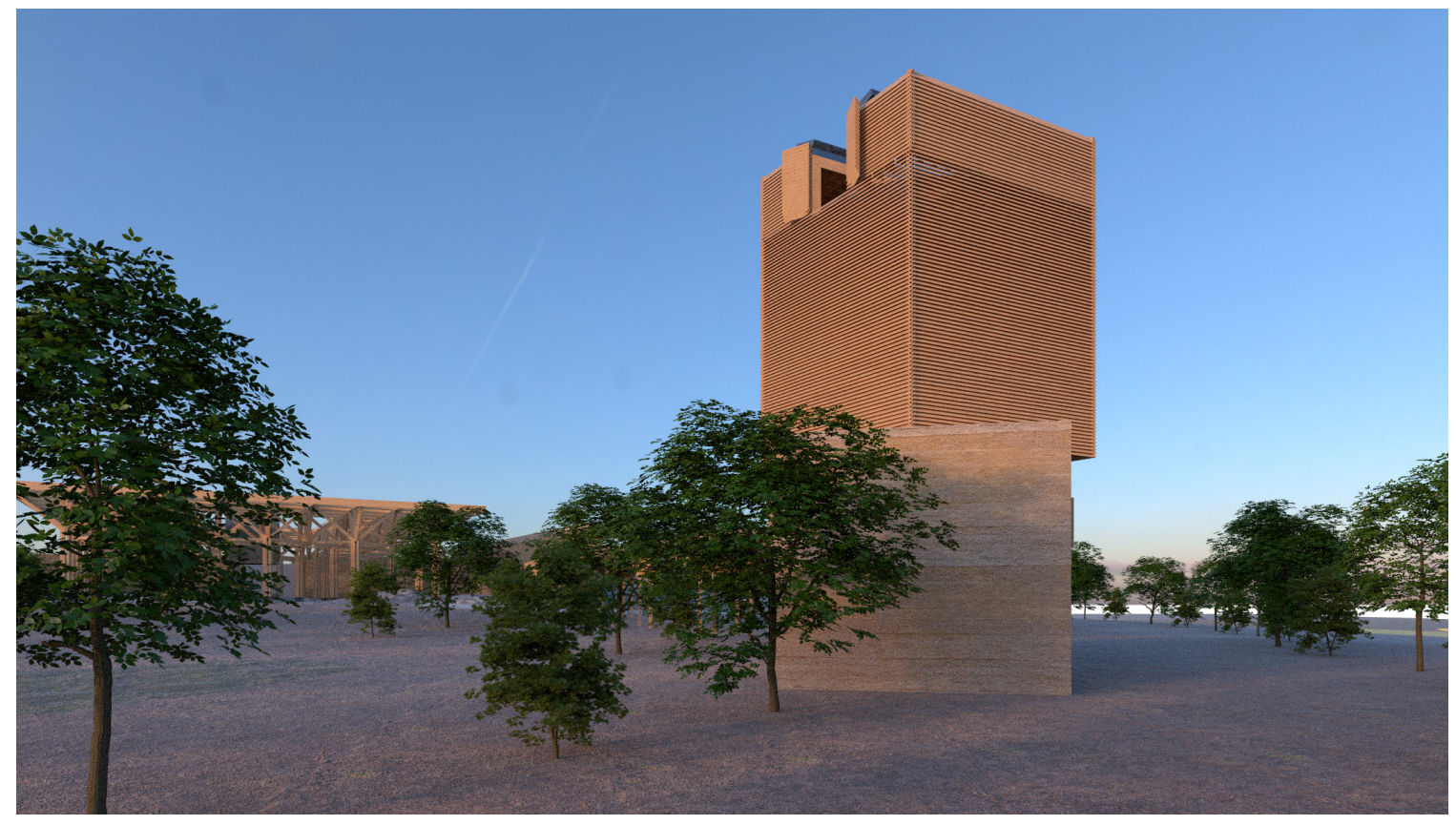




\section{Observation Tower}

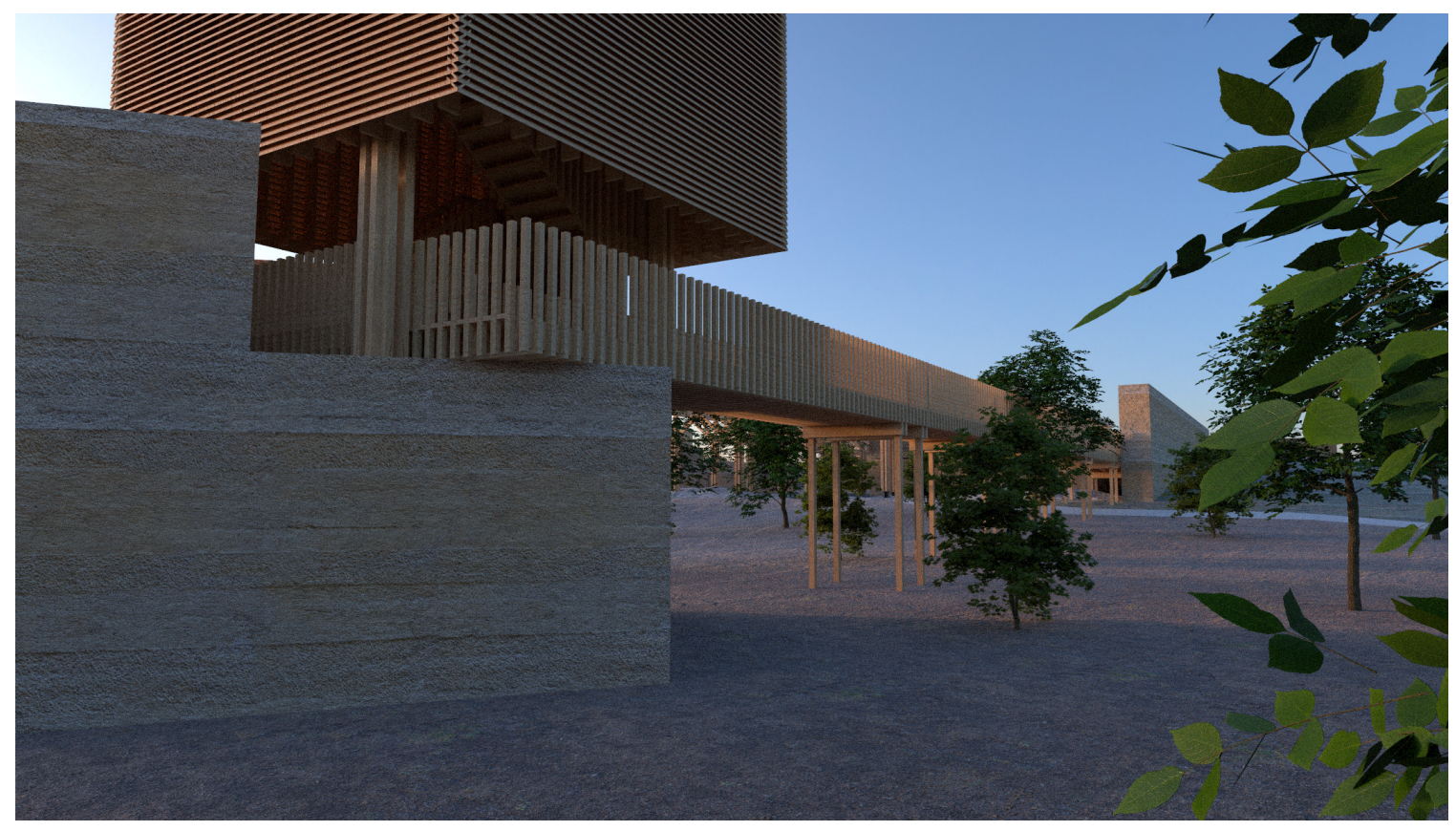

The semi enclosed tower is clad in angled

time louvres through which the brances

will eventually peak, intruding on the

isolated scientific wonder of the telescope

with natural growth 


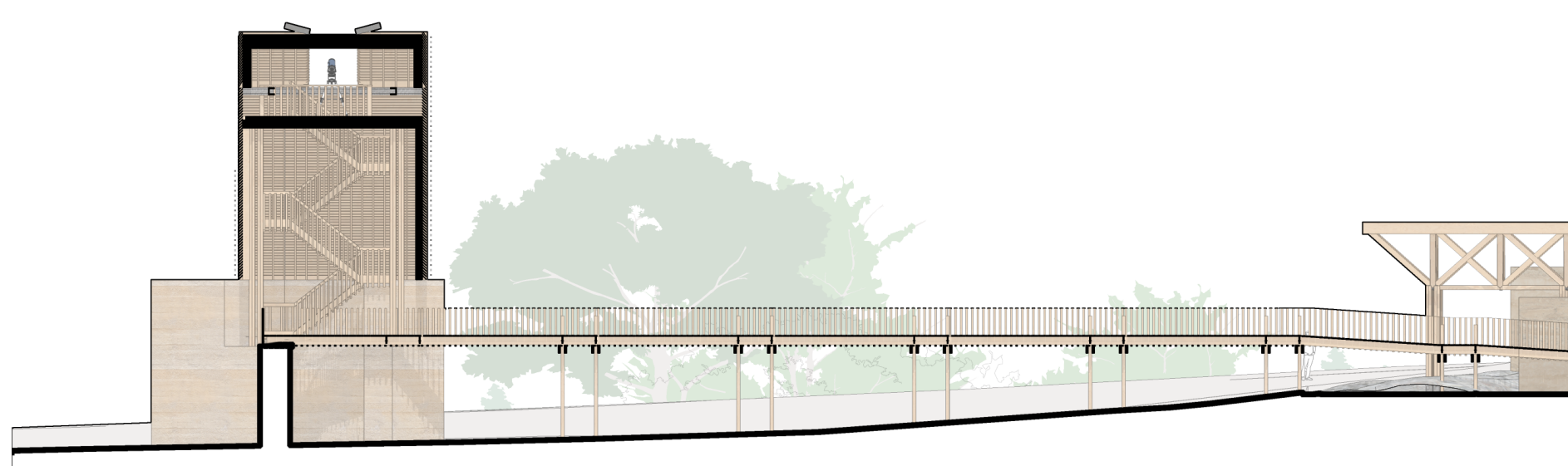




\section{Long Section A}
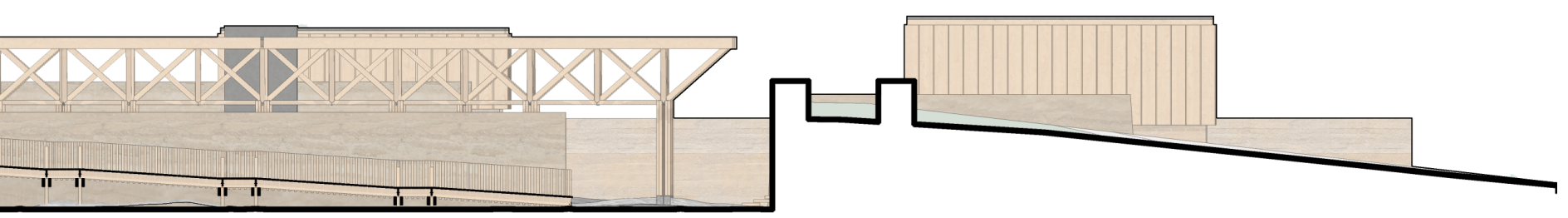

An elevated pathway connects the activity centres at the peak of the site with the observatory which takes advantage of Howe Island's status as a dark sky site. At the peak of the tower a rotation turrent contains a fixed azimuthal equidistant telescope, allowing famillies to explore the cosmos after finding their roots and enjoying the tastes of the soils around them. 


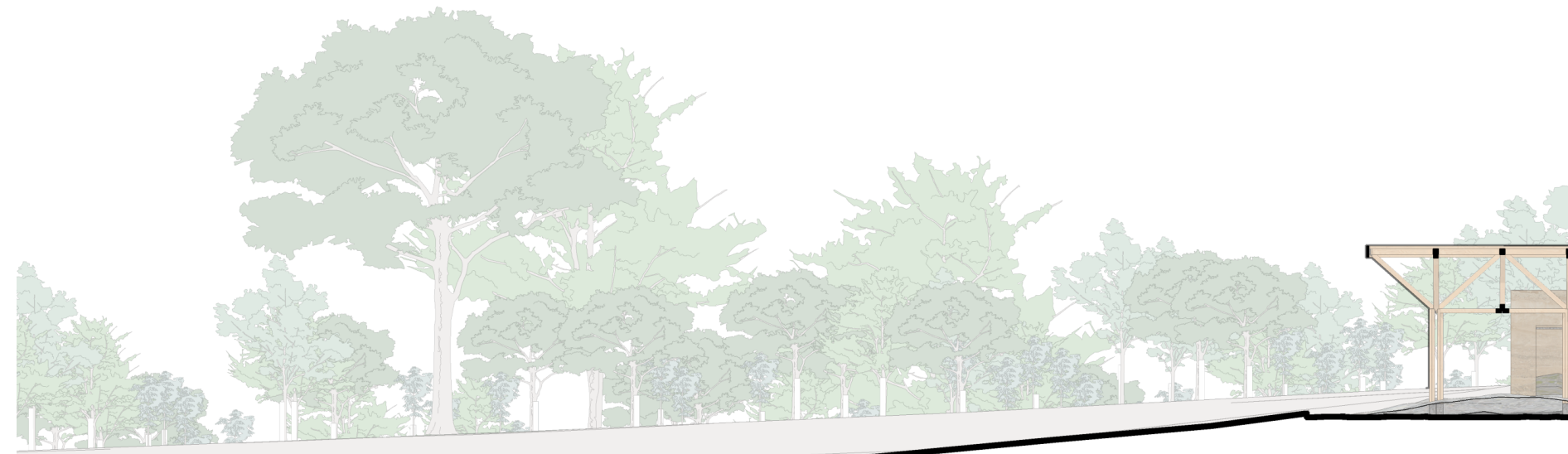

$\Gamma$ 


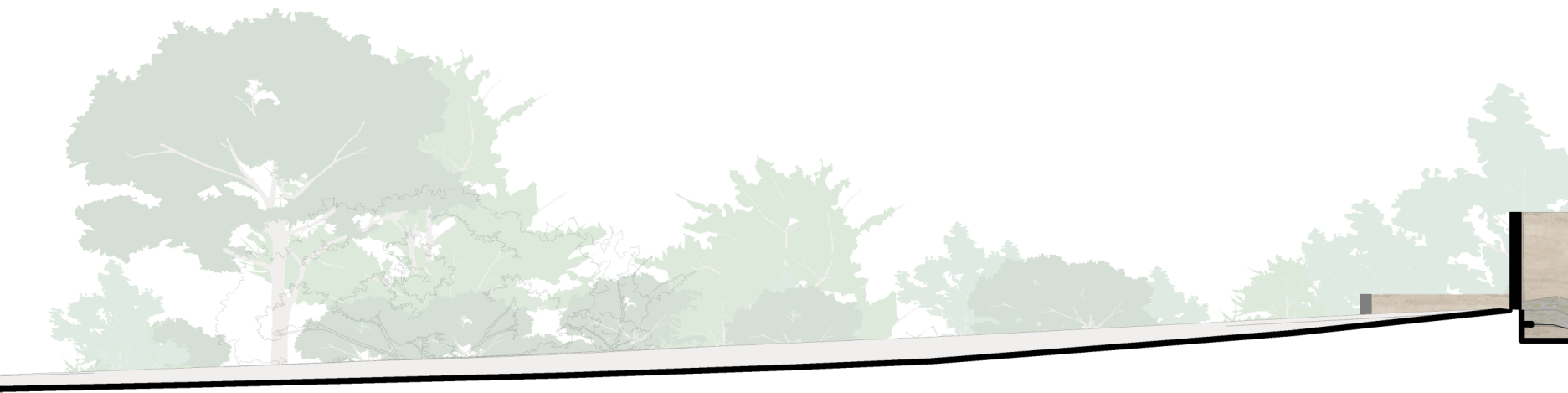




\section{Long Section C}

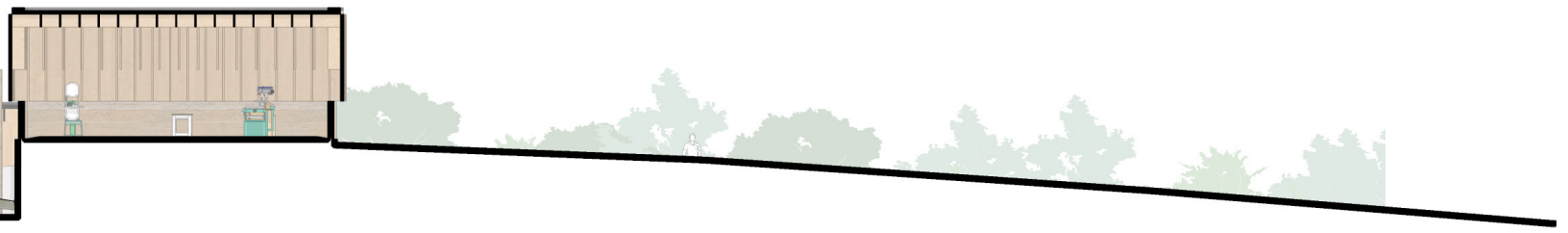

The North end of the instrument is comprised of another pair of volumes, one untempered rammed earth enclosure which will slowly erode to expose the lumber storage area to the site as a whole, and the again elevated, rammed earth and bleached chestnut timber woodshop. This shop will be the main work station of the apprenticeship program, hence it's location facing away from the site entrance minimal disturbances. 


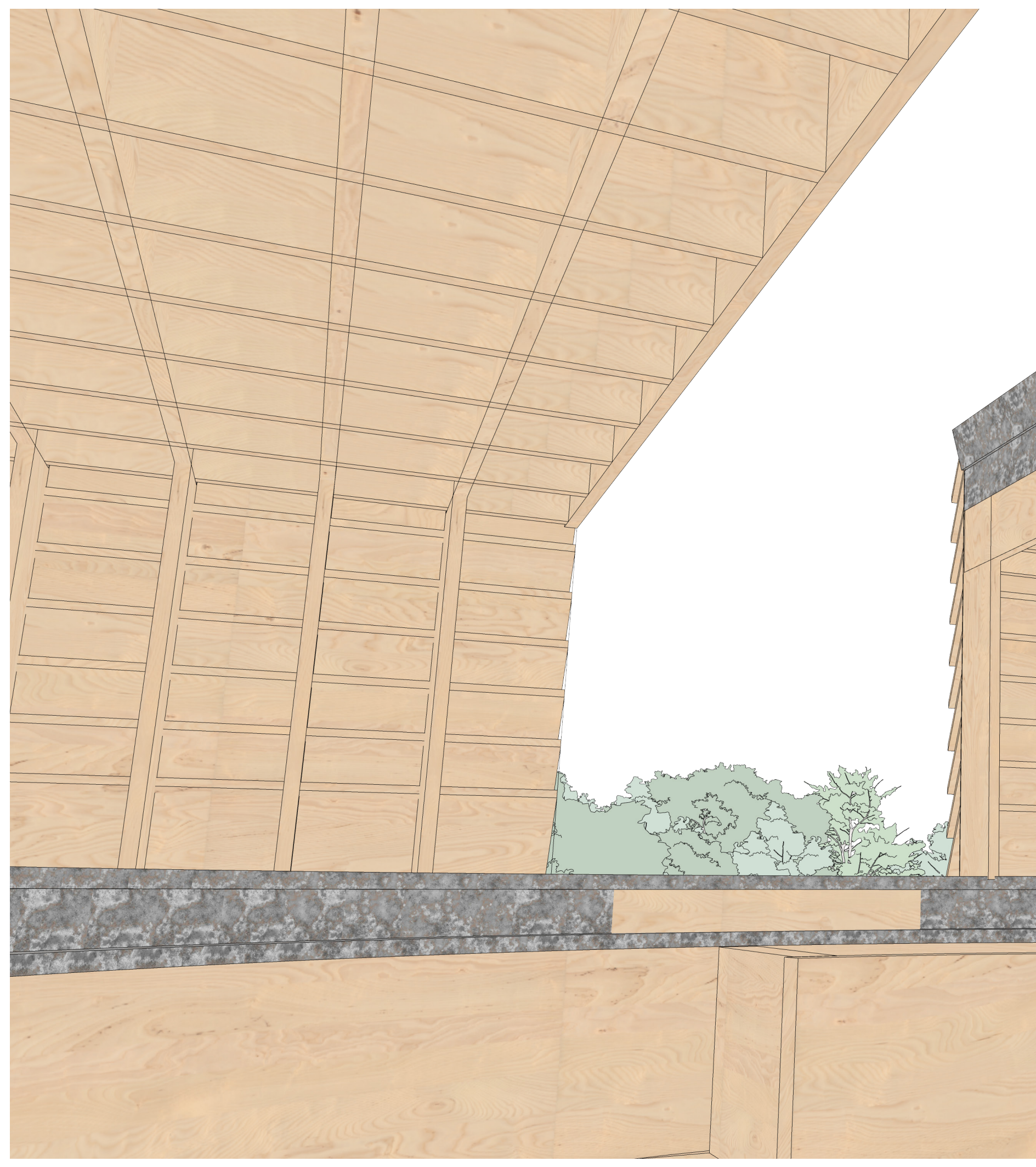




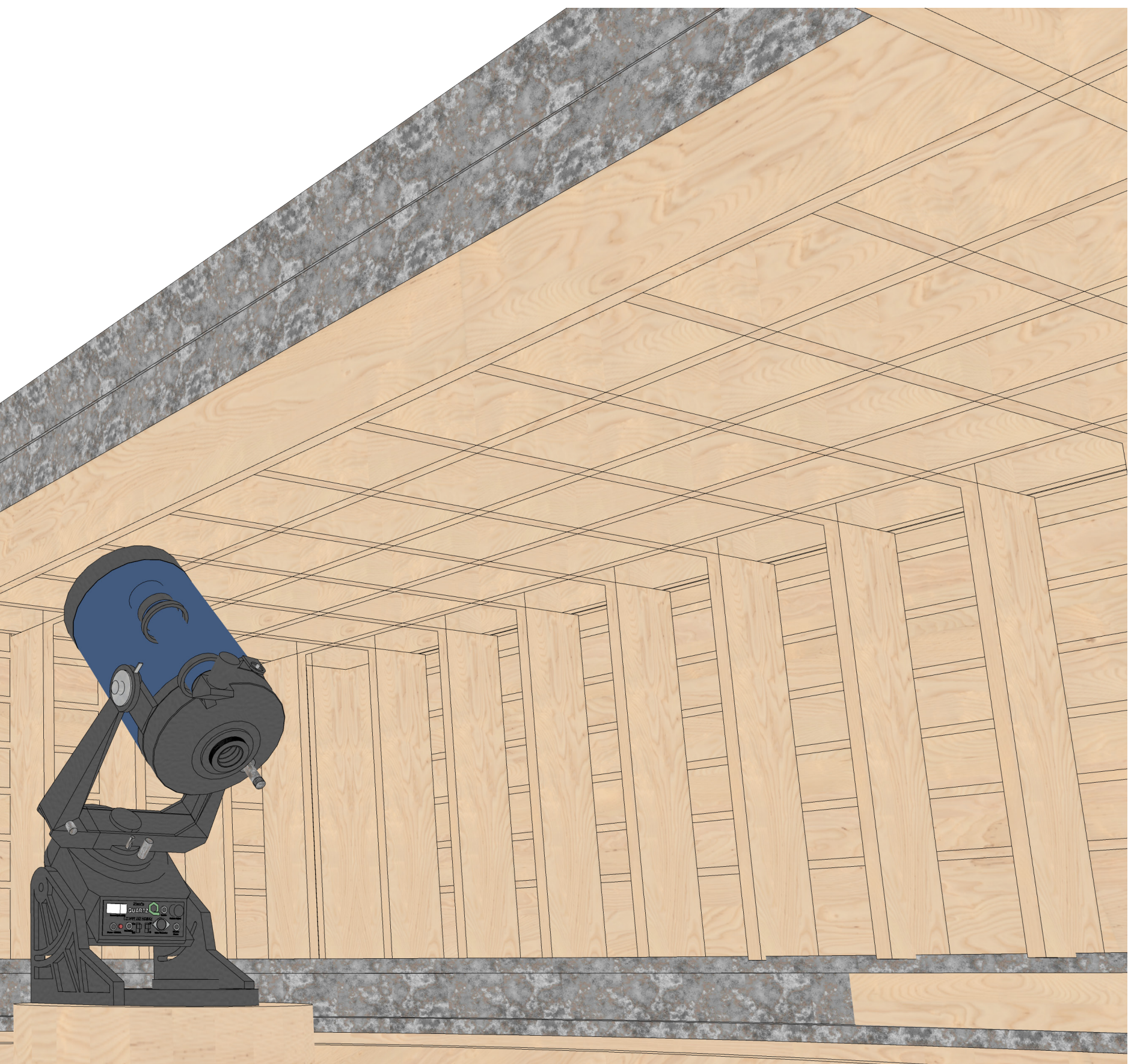

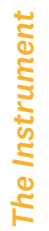




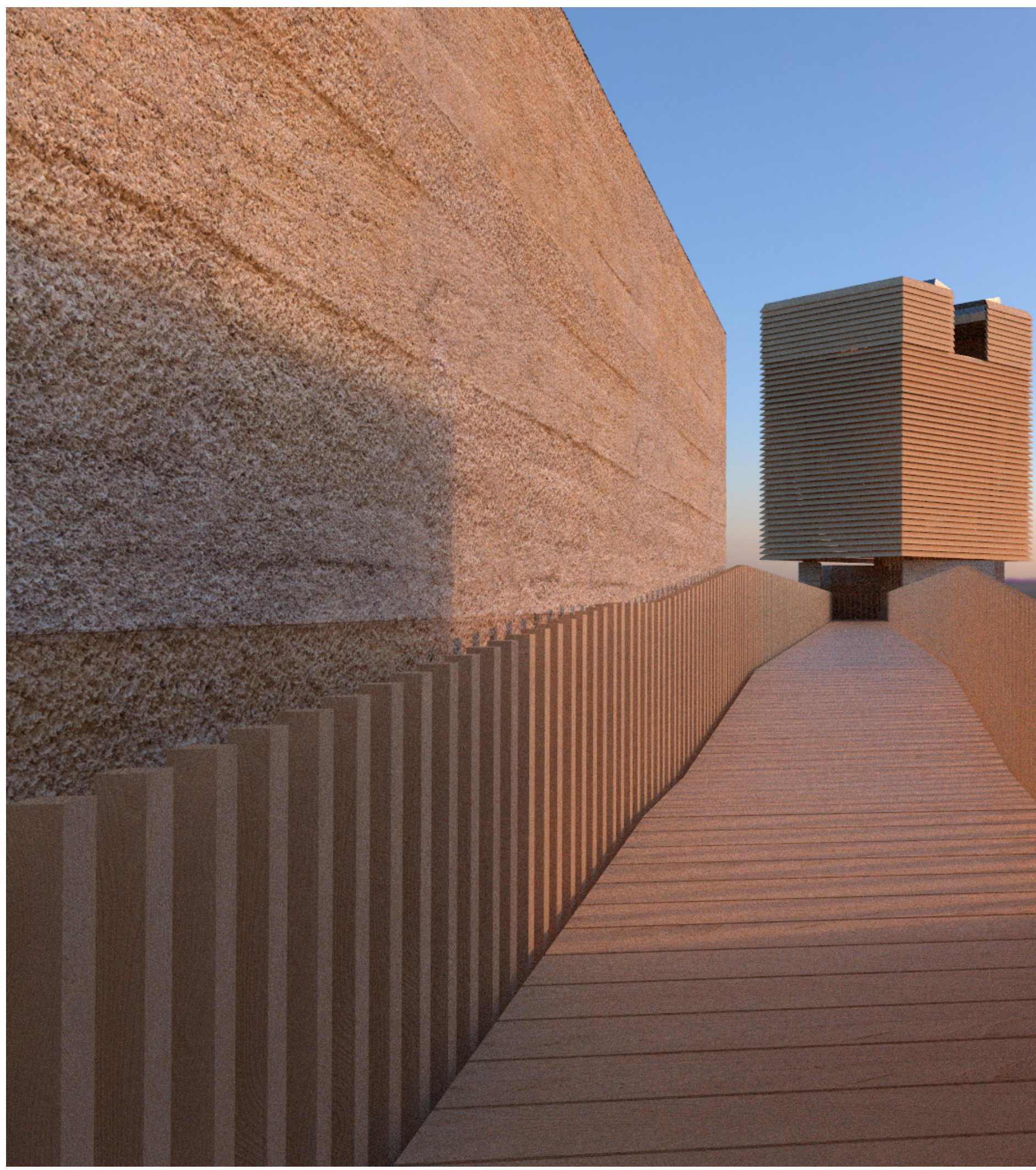




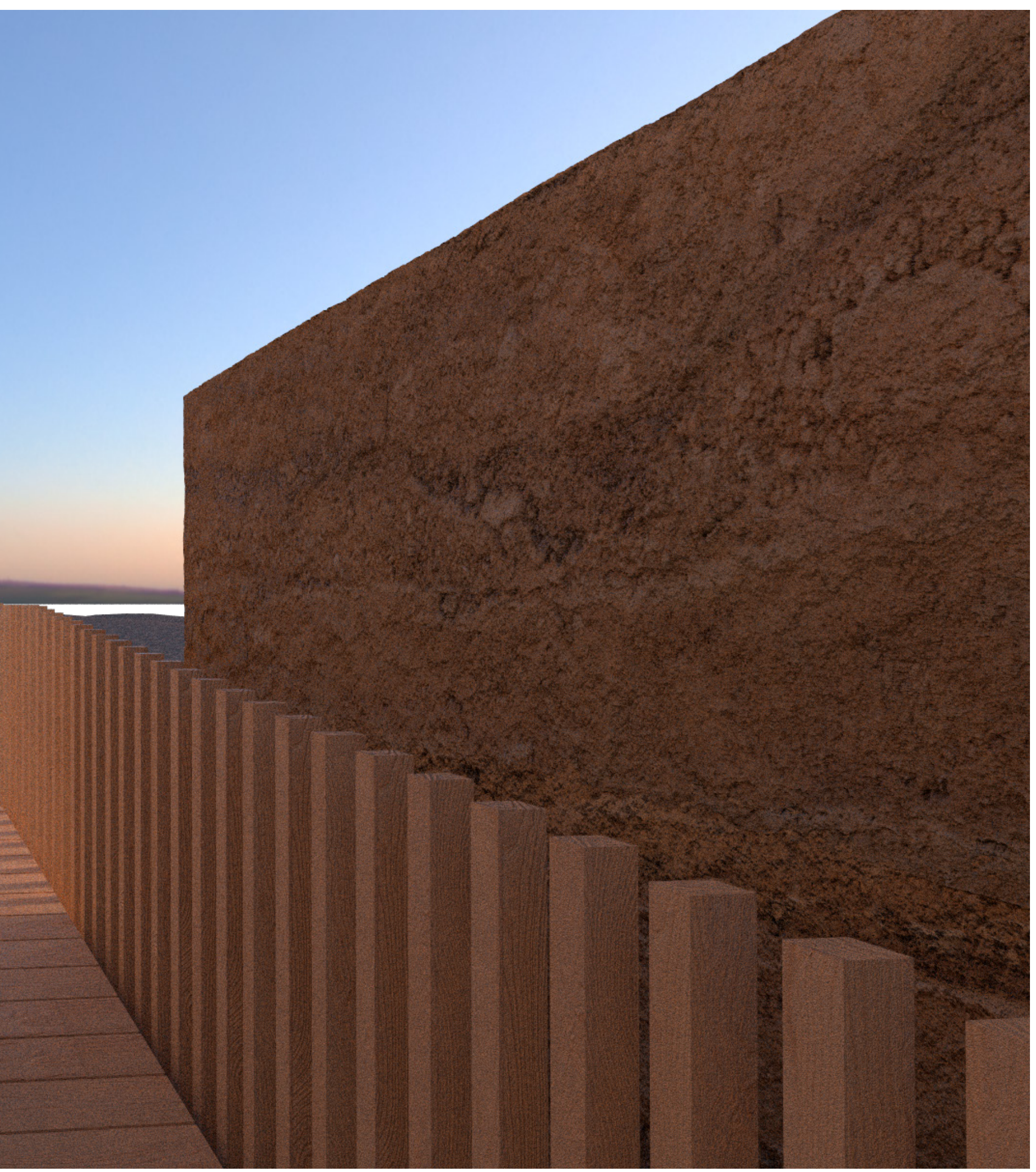

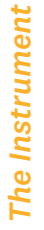




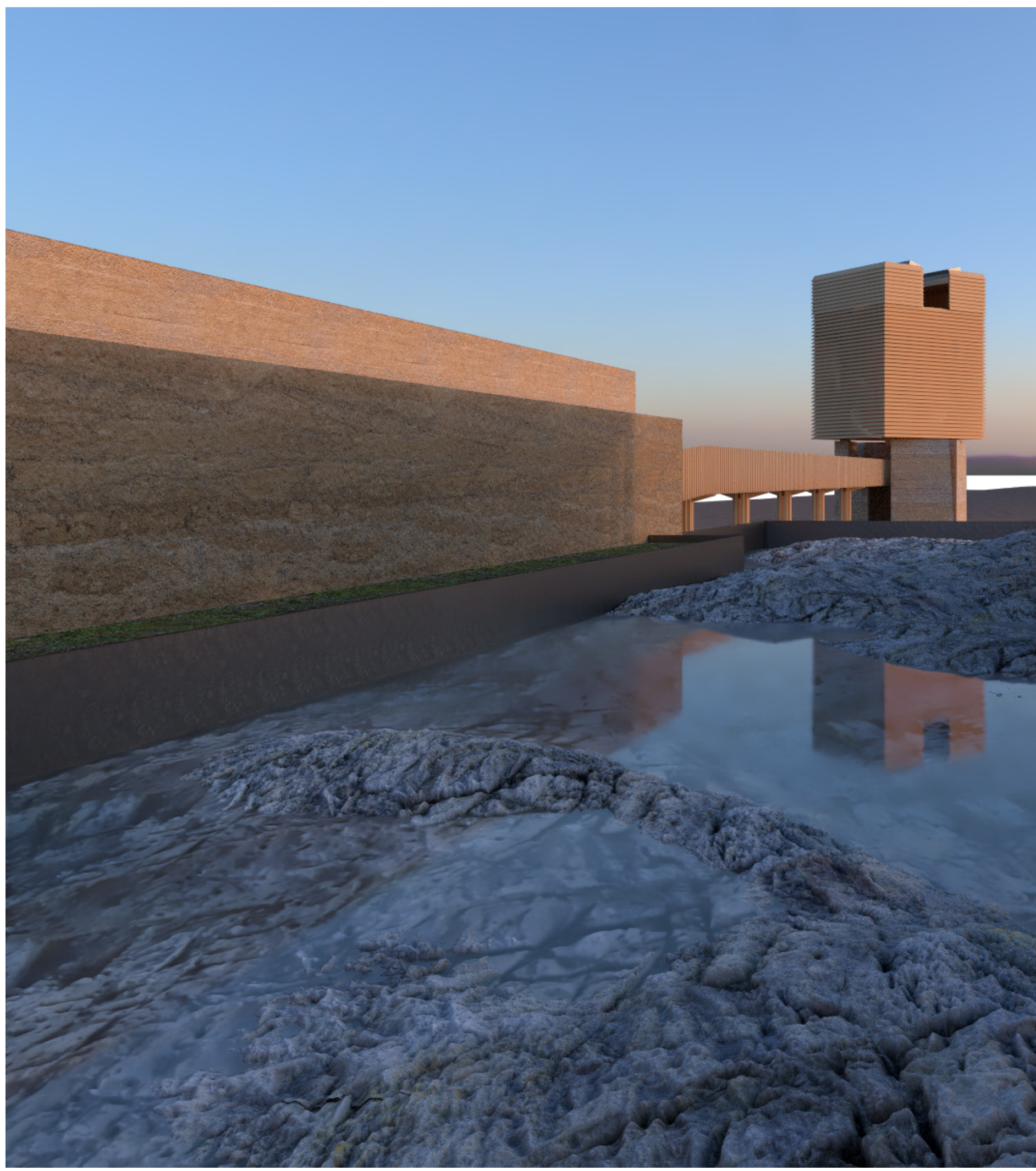




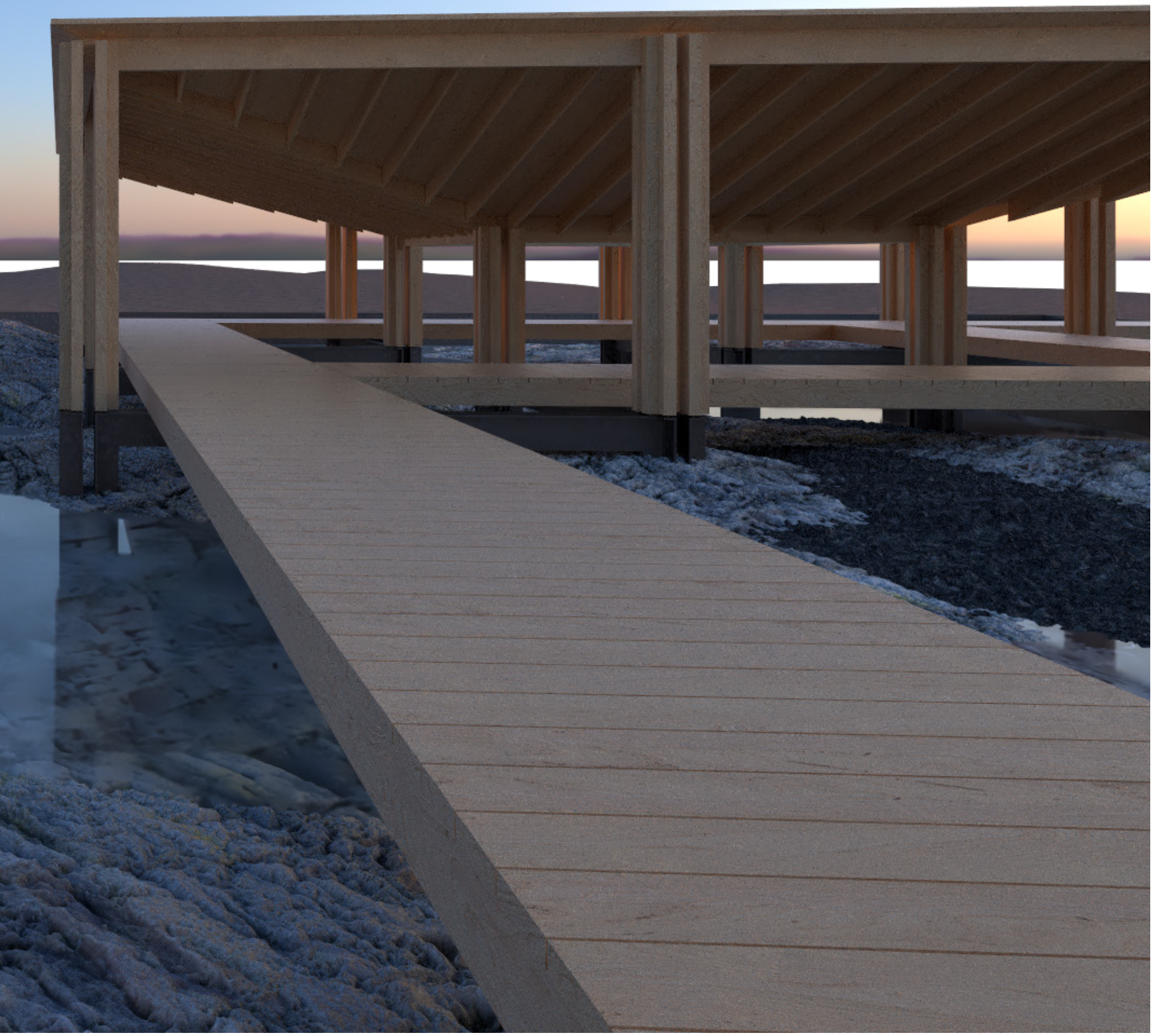




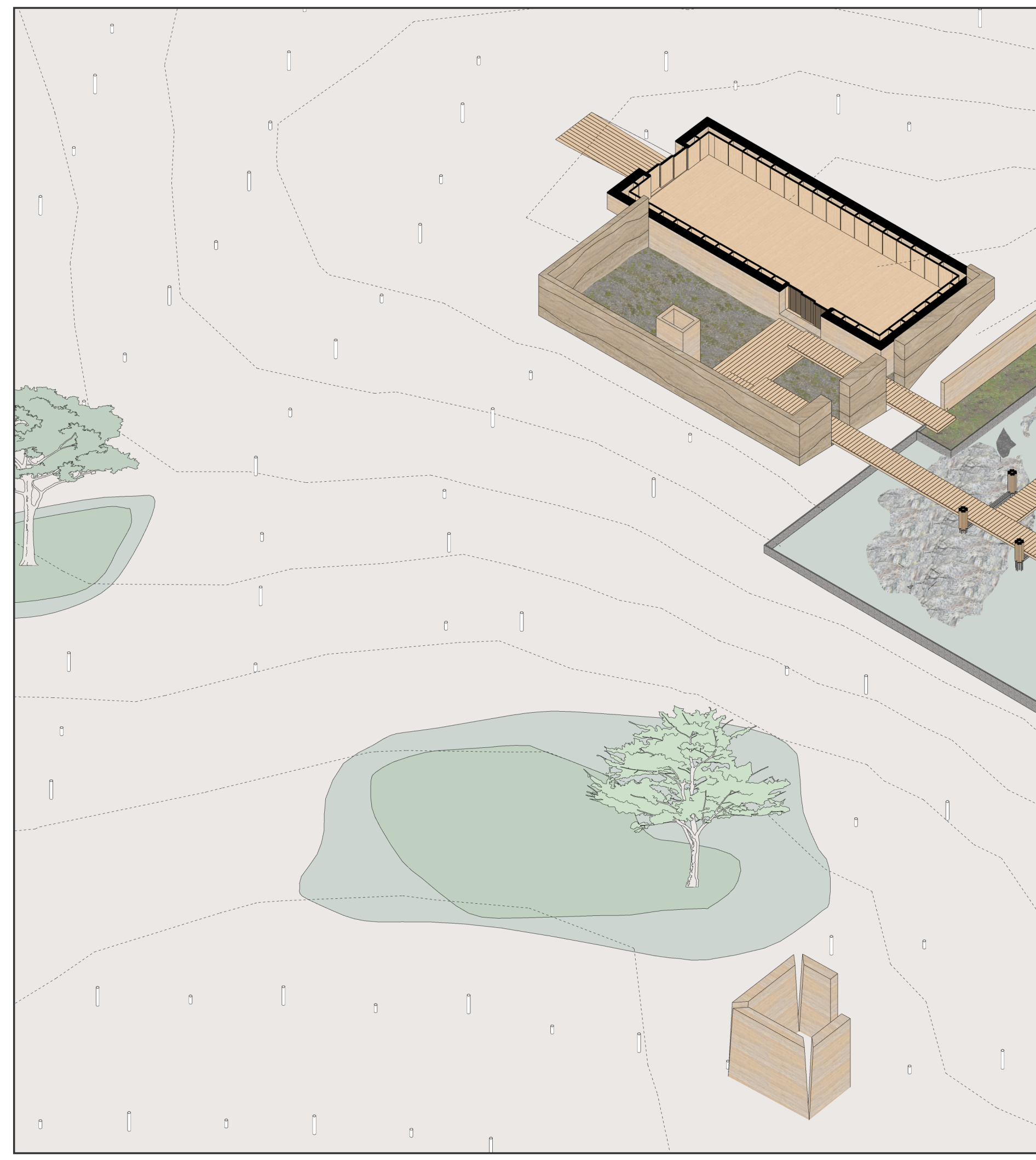




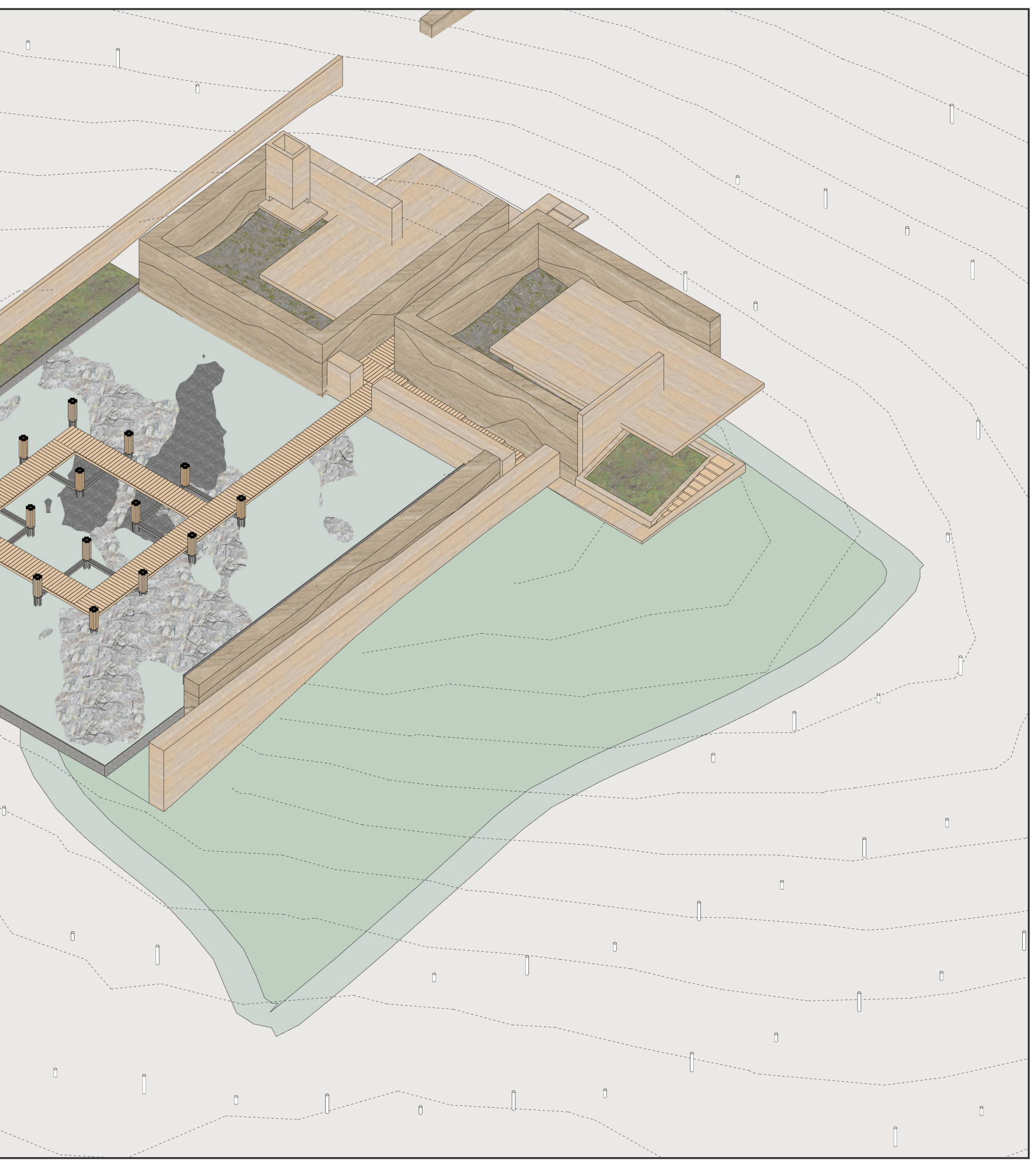




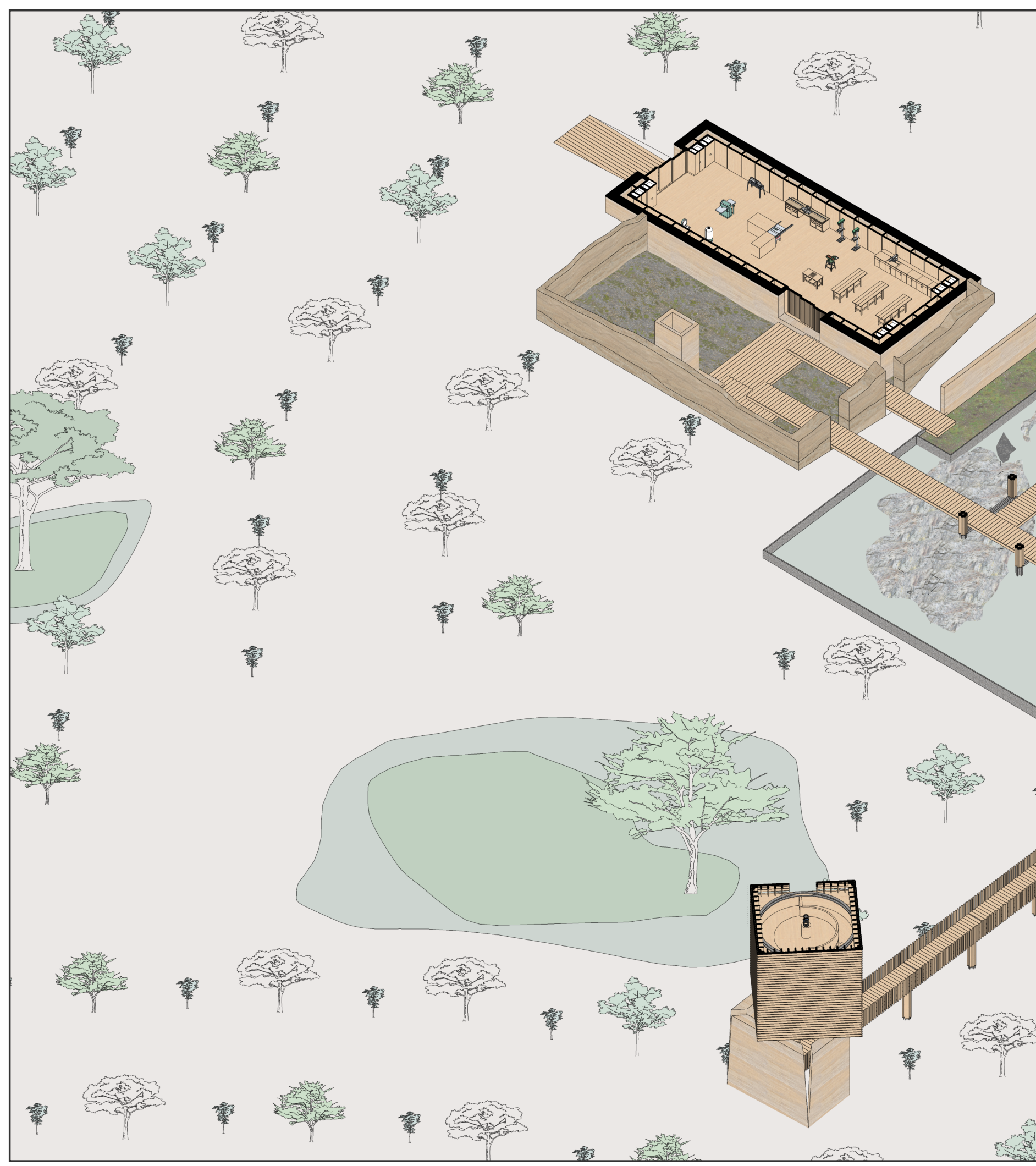




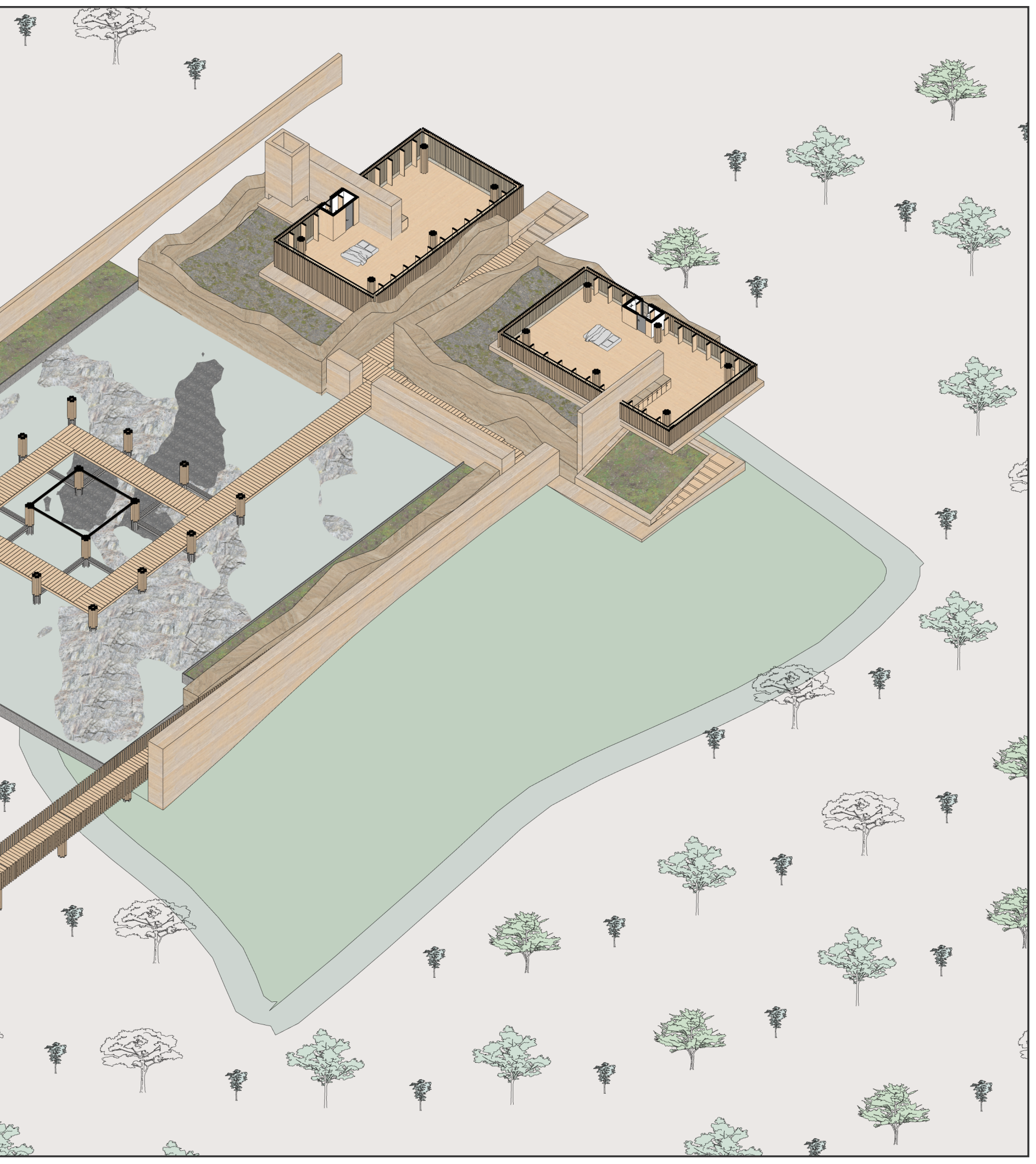




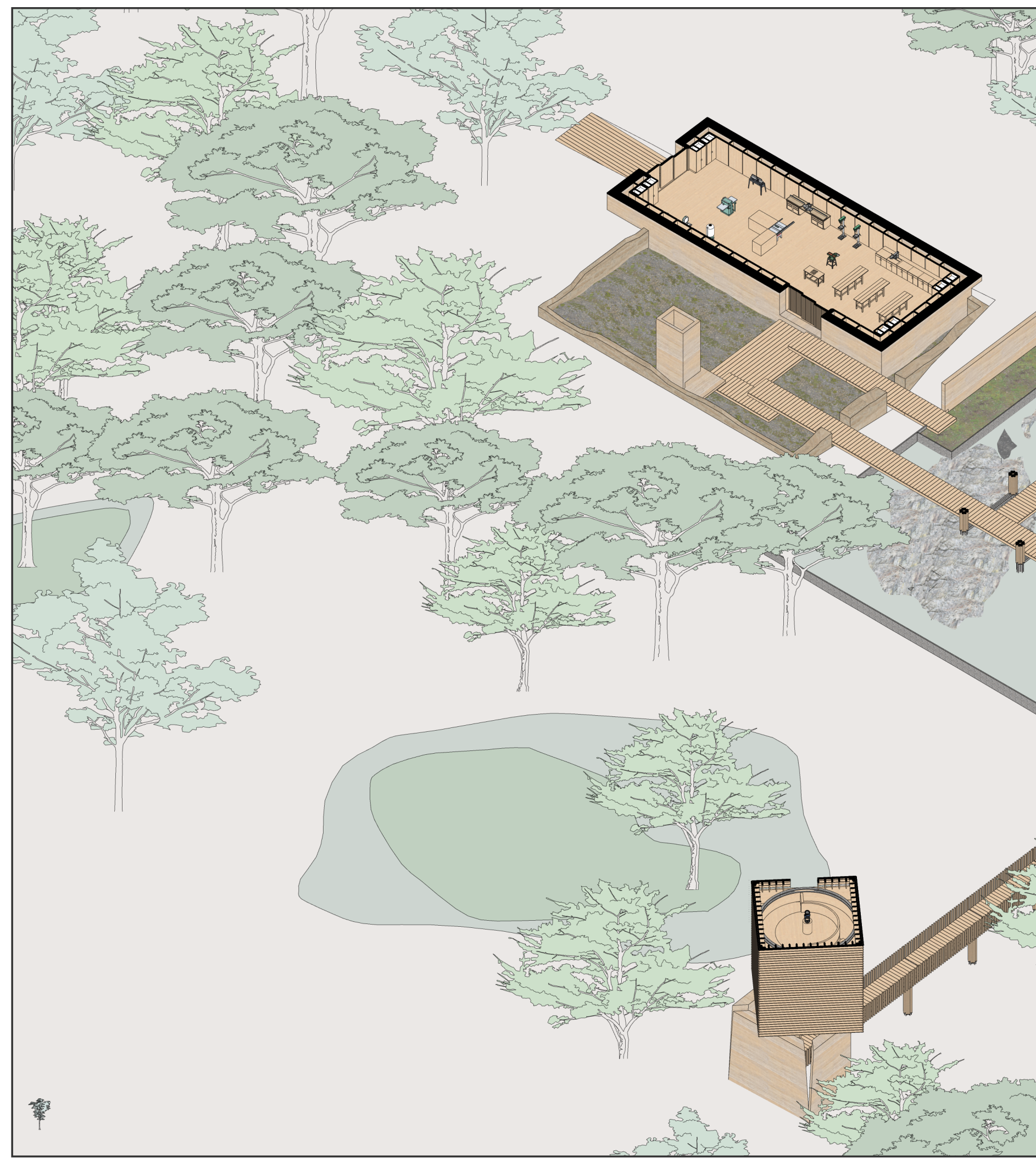





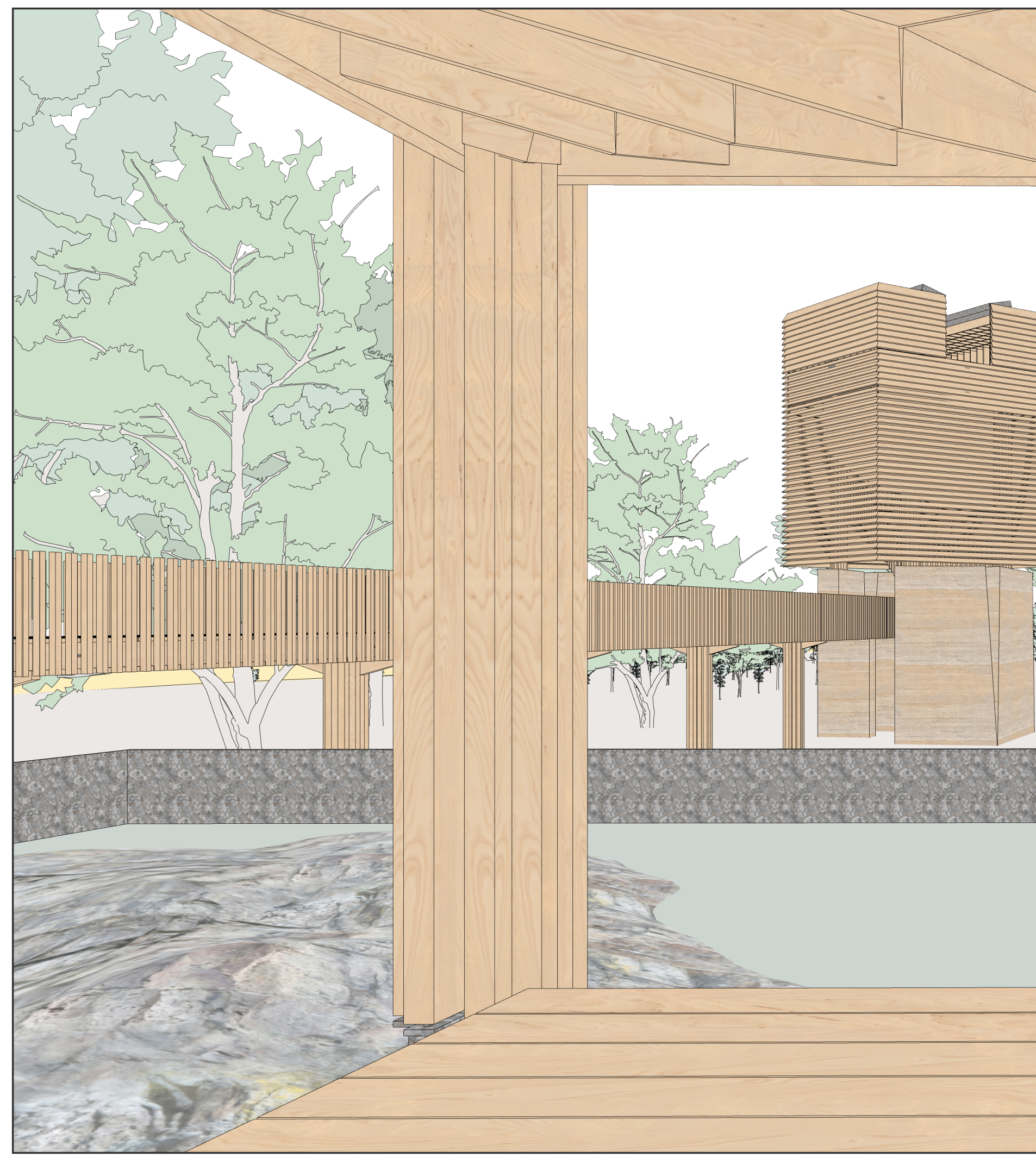




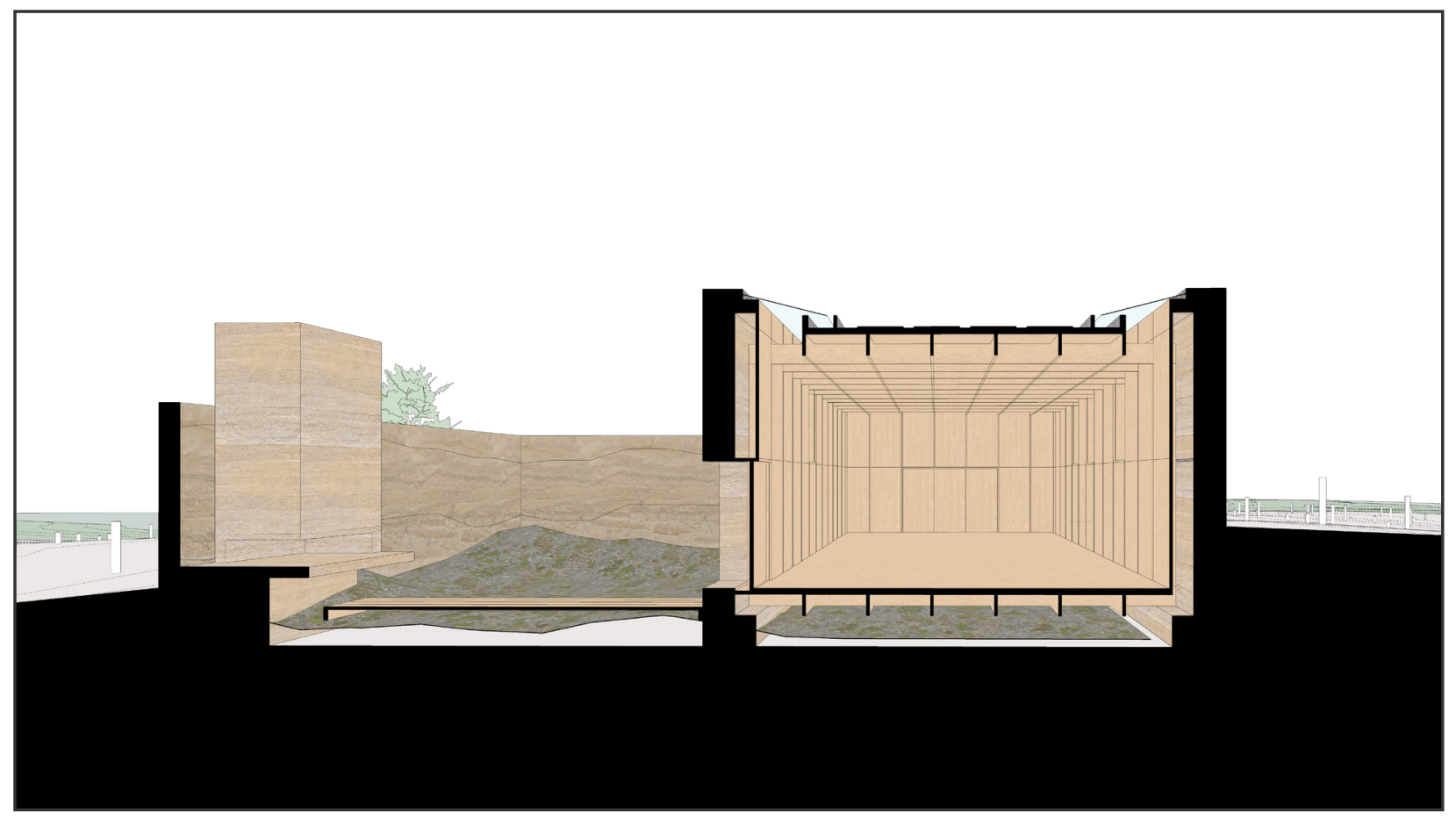



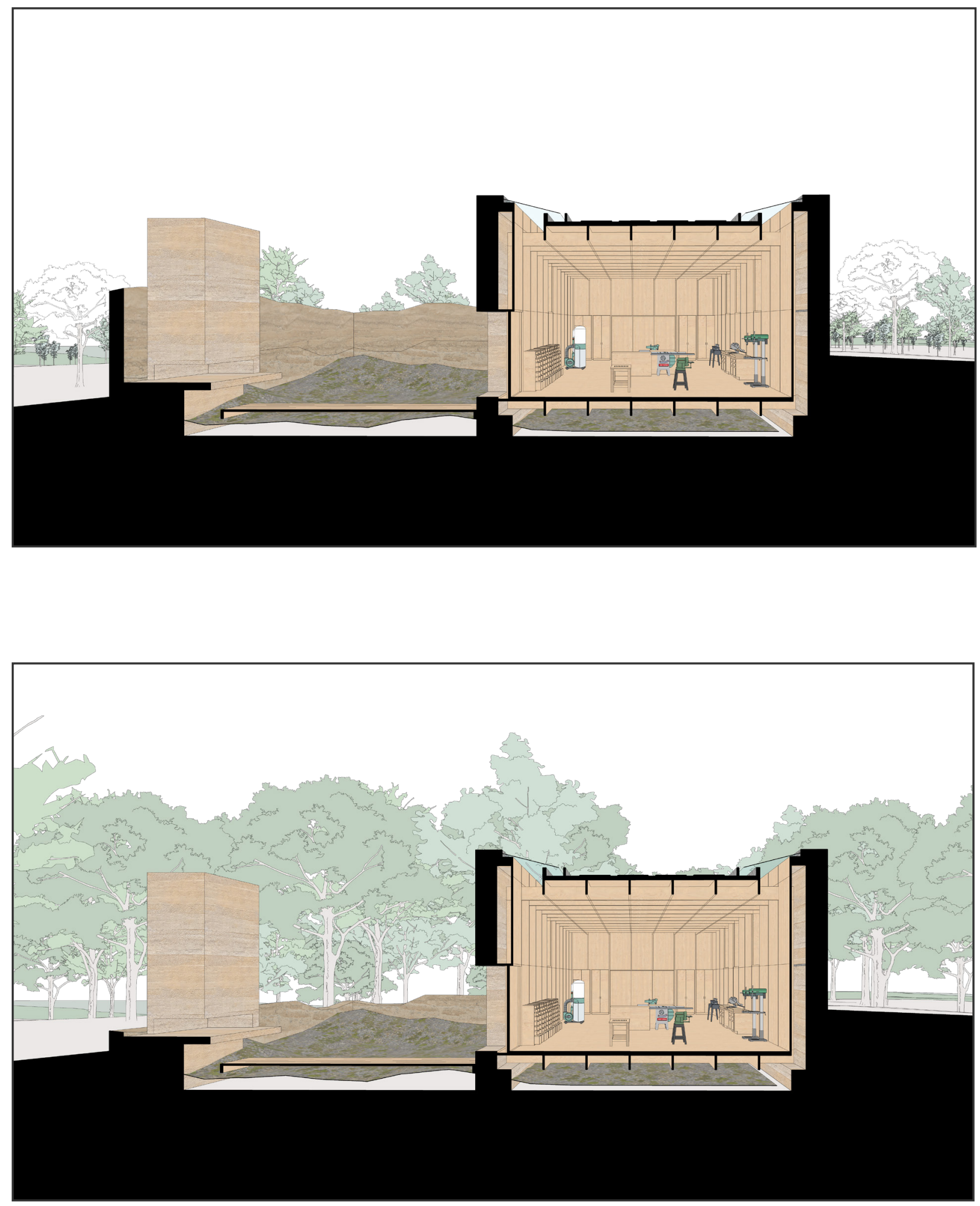


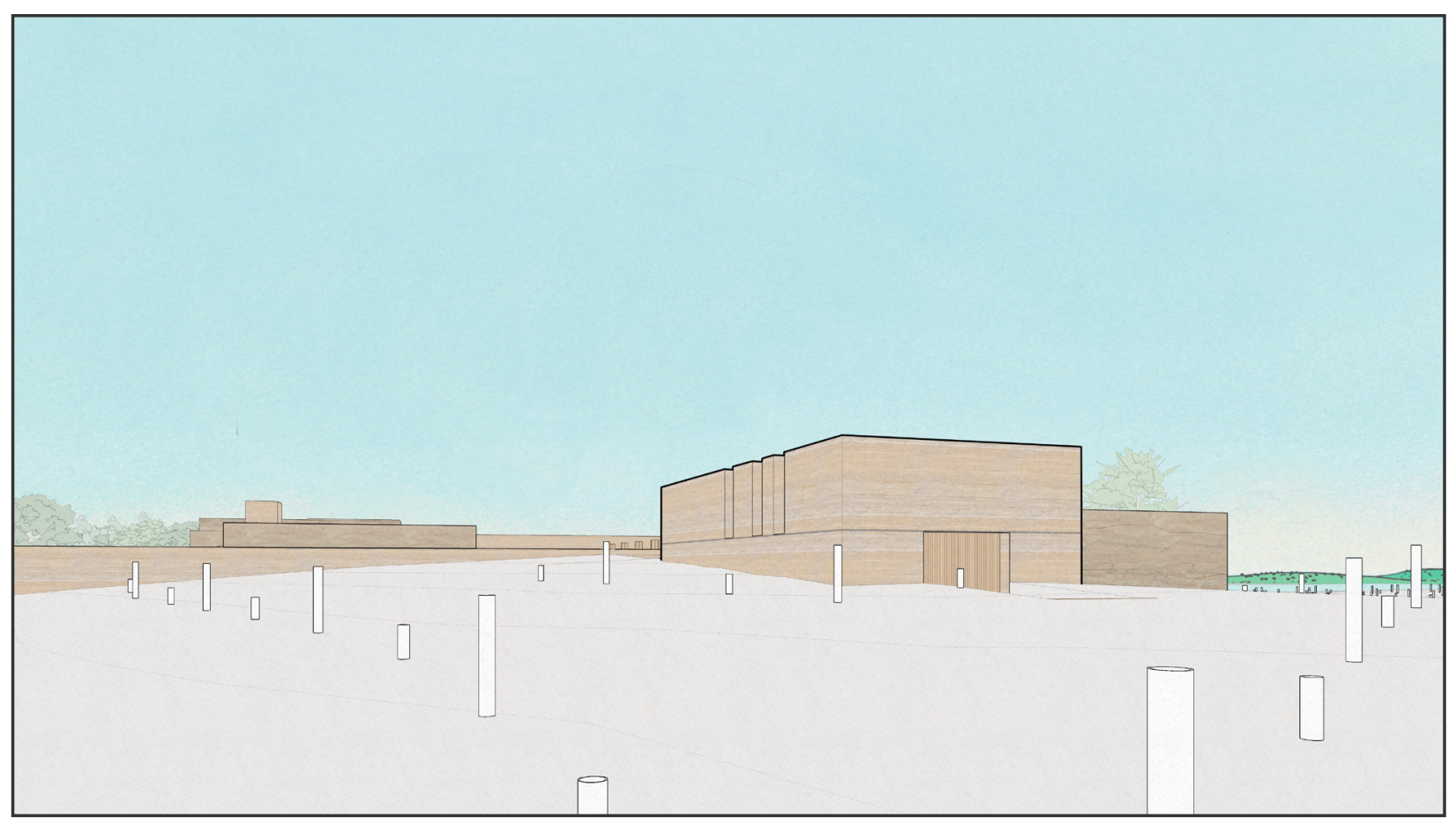



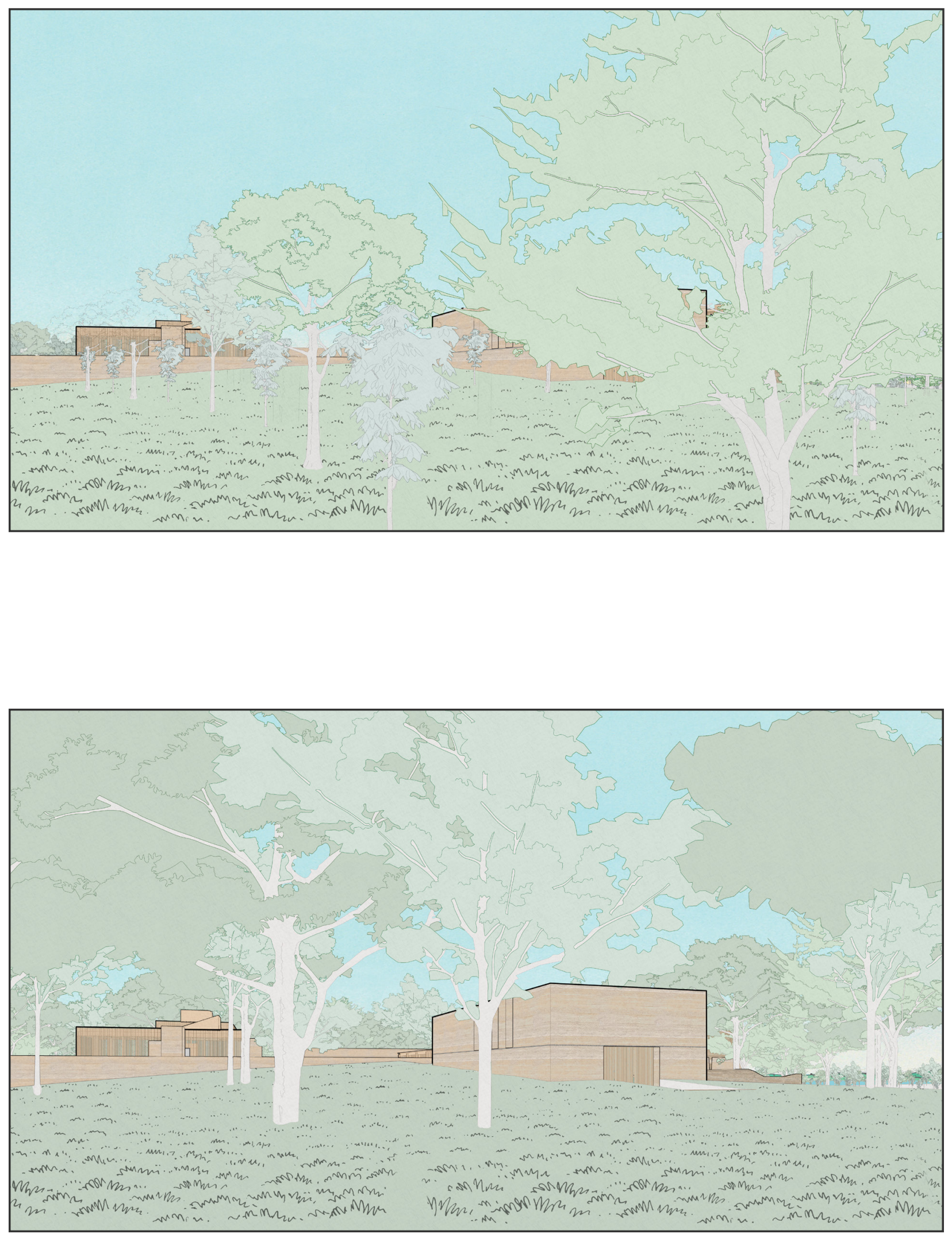

End Matter 
Abramson, D. M. (2016). Obsolescence: an architectural history. Chicago: The University of Chicago Press.

Banham, R. (1984). The architecture of the welltempered environment. University of Chicago Press.

Bataille, G. (1988). The accursed share: an essay on general economy (Vol. I).

Bennett, J. (2010). Vibrant Matter: A political ecology of things. Durham: Duke University Press.

Bernard Kenniff, T. (2010, October). Thoughts on the ethics of representation. Retrieved from http:// www.hipo-tesis.eu/fscommand/F/04.pdf

Bonnie L. Henson, Daniel T. Kraus, Michael J. McMurtry, D. N. E. (2010). Islands of Life: A Biodiversity and Conservation Atlas of the Great Lakes Islands.

Bowring Jacky, S. S. (2013). Shifting Landscapes In-Between Times. Harvard Design Magazine, (36). Retrieved from http://www. harvarddesignmagazine.org/issues/36/shiftinglandscapes-in-between-times

Corner, J., \& Hirsch, A. B. (2014). The landscape imagination: collected essays of James Corner, 1990-2010. New York: Princeton Architectural Press.

Davidson, C. C., Sola-Morales, Ignasi de, \& Anyone Corporation. (1995). Anyplace, Terrain Vague, New York, N.Y: Anyone Corp.

Dawkins, R. (2016). The Selfish Gene 40th Anniversary Edition. New York, NY: Oxford Univ Press. First edition published 1976 .
Deleuze, G., \& Guattari, F. (1987). A Thousand Plateaus: Capitalism and Schizophrenia. Minneapolis: University of Minnesota Press.

The Ellen McArthur Foundation. (2017). Circular Business Models for the Built Environment. BAMand ARUP.

Enriquez, J., \& Gullans, S. (2016). Evolving ourselves: redesigning the future of humanity--one gene at a time. NY, NY: Current.

Esteban, C. (2015, June 19). A Quick Guide to Spotting Graphics That Lie. Retrieved from http://news. nationalgeographic.com/2015/06/150619-datapoints-five-ways-to-lie-with-charts/

Ford, E. (1997). Harvard Design Magazine: The Theory and Practice of Impermanence.

Friedman, A. (2007, March 1). North by North Housing. Canadian Architect.

Foy, R. (2004). Architecture of Change: Design Adjusts to the Age of Flux. Retrieved November 14, 2017, from https:/www.di.net/articles/architecture-ofchange-design-adjusts-to-the-age-of-flux/

Gómez, A. P., \& Pelletier, L. (2000). Architectural representation and the perspective hinge. Cambridge, MA: MIT Press.

Goodman, Martin. \& Thornton, James. \& Eno, Brian. (2017). Client earth. Brunswick, Victoria : Scribe Publications

Gould, S. J., \& Lewontin, R. C. (1979). The Spandrels of San Marco and the Panglossian Paradigm: A Critique of the Adaptationist Programme. Proceedings of the Royal Society B: Biological 


\section{References}

Sciences, 205(1161), 581-598. doi:10.1098/

rspb.1979.0086

Ginn, F., \& Demeritt, D. (2008). Nature: A Contested

Concept. Key Concepts in Geography, (June 2009), 480.

Girot, C. (2013). Immanent Landscape. Harvard Design Magazine, (36). Retrieved from http://www. harvarddesignmagazine.org/issues/36/immanentlandscape

Gouvernement du Québec. (n.d.). Great Lakes StLawrence River Basin Sustainable Water Resources Agreement. Retrieved April 4, 2018, from http://www.mddep.gouv.qc.ca/eau/ grandslacs-en/2005/index.htm\#great

Graham, J., Blanchfield, C., Anderson, A., Carver, J., \& Moore, J. (2016). Climates : architecture and the planetary imaginary. Lars Müller.

Handa, R. (2015). Allure of the Incomplete, Imperfect, and Impermanent: Designing and Appreciating Architecture as Nature. London: Routledge.

Haraway, D. J. (2003). The companion species manifesto: Dogs, people, and significant otherness. Chicago : Prickly Paradigm Press

Haraway, D. J. (2016). Staying with the trouble: Making kin in the Chthulucene. Durham : Duke University Press

Henrich, J. P. (2015). The secret of our success: How culture is driving human evolution, domesticating our species, and making us smarter. Princeton: Princeton University Press.

Ibañez, D., \& Katsikis, N. (2014). Grounding
Metabolism. New Geographies, 6. Cambridge, MA: Harvard University Graduate School of Design.

Jackowski, N., \& Ostos, R. D. (2008). Pamphlet Architecture, Volume 29: Ambiguous Spaces. Princeton Architectural Press.

Jansen, T. (2007). The Great Pretender. Rotterdam: 010. Jensen, K. G., \& Sommer, J. (2016). Building a circular future. Kobenhavn: GXN Innovation.

Jones, D. (2015). Morality 2.0: How manipulating our minds could save the world. The New Scientist, 1-8. Retrieved from https://www.newscientist. com/article/mg22730400-700-morality-2-0-howmanipulating-our-minds-could-save-the-world/

Klein, N. (2015). This changes everything: capitalism vs. the climate. Toronto: Vintage Canada.

Koolhaas, R., Obrist, H., Ota, K., \& Westcott, J. (2011). Project Japan: Metabolism talks ... Koln: Taschen.

Latour, B. (2013). An inquiry into modes of existence: An anthropology of the moderns. Cambridge, Massachusetts : Harvard University Press

Latour, B. (2017). Facing Gaia : eight lectures on the new climatic regime. Cambridge, UK: Polity.

Lin, Z. (2010). Kenzo Tange and the Metabolist movement: urban utopias of modern Japan.

Lindeman, E.C. (1940). Ecology: An Instrument for the Integration of Science and Philosophy, in Ecological Monographs, Vol. 10, No. 3, pp. 367372

Leopold, Aldo, 1886-1948. (1949). A Sand County almanac, and Sketches here and there. New York 
:Oxford University Press

Lovelock, J. (2000). Gaia: A new look at life on earth. Oxford: Oxford University Press.

Manaugh, G. (Ed.). (2013). Landscape Futures. Reno, Nevada: ACTAR. Retrieved from https://issuu. com/actar/docs/landscape_futures

Mariani, Manuela \& Barron, Patrick, (2014). Terrain vague : interstices at the edge of the pale (First edition). Routledge, New York

Mathews, S. (2005). The Fun Palace: Cedric Price's experiment in architecture and technology. Technoetic Arts, 3(2), 73-92. doi:10.1386/ tear.3.2.73/1

Mayer H., J. (Jürgen), \& Bhatia, N. (2010). -arium : weather + architecture. Hatje Cantz.

Milton, A. (2014, October 17). Ignoble Lies. Retrieved from http://www.socialmatter.net/2014/10/17/ ignoble-lies/

Moe, K. (2013). Convergence: An Architectural Agenda for Energy (1st ed.). London and New York: Routledge.

Moe, K. (2014). Insulating modernism. Birkhauser Architecture.

Morton, T. (2017). Humankind: Solidarity with nonhuman people. Brooklyn, NY : Verso

Mostafavi, M., \& Leatherbarrow, D. (1993). On weathering : the life of buildings in time. MIT Press.

Napawan, N.C., Burke E., \& Yui S. (2017, November). Women's Work: An Eco-Feminist Approach to Environmental Design. the Avery Review 27.
Retrieved from http://averyreview.com/issues/27/ womens-work.

Nyilas, A., \& Kurazumi, Y. (2017). On the Aesthetics of Seasonally Adaptive Buildings - A Morphological Approach towards Climate Responsive Architecture, 7(4), 146-158. https://doi. org/10.5923/j.arch.20170704.03

Plato. (2008). The Republic. Project Gutenberg. Popko, J. (2014). The Instrument and the Atlas: Metalepsis as a Lens for Reading the City. Univsersity of Cincinnati. Retrieved from http://rave.ohiolink.edu/etdc/view?acc num $=\mathrm{ucin} 1406811071$

Richerson, P. J., \& Boyd, R. (2005). Not by genes alone: How culture transformed human evolution. Chicago: University of Chicago Press.

Ruff, A. (2012). Fiction of the Earth. Ground Up, (1), 53-55. Retrieved from https:// issuu.com/groundupjournal/docs/issue01_ landscapesofuncertainty

Salingaros, N., \& Mikiten, T. (2002, March). Darwinian Processes and Memes in Architecture: A Memetic Theory of Modernism. Journal of Memetics Evolutionary Models of Information Transmission, 6.

Sauter, F. (2018). Painting the Sky Black: Louis Kahn and the Architectonization of Nature. De Gruyter.

Smith, Z. (2018). Elegy for a Country's Seasons. In Feel Free (pp. 14-19). New York: Penguin Press.

Smout, M. (2007). Pamphlet Architecture, Volume 28 : Augmented Landscapes. Princeton Architectural 
Press,

Tange, K., \& Kawazoe, N. (1965). Ise, prototype of Japanese architecture. Cambridge, MA: M.I.T. Press.

Theodore, D. (2012). A Strange Reconciliation. Tarp: Architecture Manual, (Not Nature), 10-15. Retrieved from https://issuu.com/tarp/docs/tarp_ architecture_manual_not_nature

Ulrich Obrist, H., \& Friedman, Y. (2007). Hans Ulrich Obrist \& Yona Friedman (Vol. 7, The Conversation Series). Köln: Walther König.

Vazirnezami, S. (2015). Anti-Museum an Architectural Ecology (Unpublished master's thesis). Ryerson University, Toronto.

Williams, R. (1983) Keywords: A Vocabulary of Culture and Society. London: Flamingo.

Willis, D., Braham, W. W., Muramoto, K., \& Barber, D. A. (2017). Energy accounts: architectural representations of energy, climate, and the future. London: Routledge, Taylor \& Francis Group.

Zago, A. (2018) Accident, Art Paper Editions 

1. The noble lie was a concept for a mutual idealogy to be espoused by all citizens.

Specifically to Plato's example, that people were born with different percentages

of precious metals in their body, which would indicate which strata of a

hierarchical society with a philosopher king at the head.

2. Recently the U.S. EPA has prevented agency researchers from presenting their findings, in non-policy reports. Similar actions were executed by the Harper administration in Canada.

3. A search for mentions of 'sustainable' using Google's Ngram viewer shows a tenfold increase in published appearance of the word from 1980 to 2005 , and the trend continues with connected words, such as 'sustainability' and a doubling in 'environmental'. This correlates strongly with historical awareness of environmental impact in post-cold war western society, especially the fallout from the 1973 oil crisis.

4. “disinformation disseminated by an organization so as to present an environmentally responsible public image."

-Oxford Dictionary 
